\title{
DESEMPENHO PRODUTIVO DE TRÊS CULTIVARES DE SOJA EM DUAS ÉPOCAS DE SEMEADURA E EM CINCO DENSIDADES DE PLANTAS
}

\author{
MÔNICA CAGNIN MARTINS \\ Engenheiro Agrônomo
}

Orientador: Prof. Dr. Gil Miguel de Sousa Câmara

\begin{abstract}
Dissertação apresentada à Escola Superior de Agricultura "Luiz de Queiroz", Universidade de São Paulo, para obtenção do título de Mestre em Agronomia, Área de Concentração: Fitotecnia.
\end{abstract}

\footnotetext{
PIRACICABA

Estado de São Paulo - Brasil

Dezembro - 1998
} 
Dados Internacionais de Catalogação na Publicação (CIP) DIVISÃO DE BIBLIOTECA E DOCUMENTAÇÃO - Campus "Luiz de Queiroz"/USP

Martins, Mônica Cagnin

Desempenho produtivo de três cultivares de soja em duas épocas de semeadura e em cinco densidades de plantas / Mônica Cagnin Martins. - Piracicaba, 1998.

$84 \mathrm{p}$.

Dissertação (mestrado) - - Escola Superior de Agricultura Luiz de Queiroz, 1998.

Bibliografia.

1. Densidade de planta 2. Época de semeadura 3. Produtividade vegetal 4. Rendimento vegetal 5. Soja 6.Variedade I. Titulo 
A Deus

Aos meus pais Edmilson e Maria Alice

Aos meus irmãos Marise, Mauricio e Marcio

Ao Marco Antonio Tamai

Ofereço e Dedico 


\section{Agradecimentos}

Ao Prof. Dr. Gil Miguel de Sousa Câmara pela orientação, estímulo, confiança, e amizade demonstrada durante nosso convívio.

Ao Prof. Dr. Natal Antonio Vello pela oportunidade para realização do aperfeiçoamento de ensino e por ter sido o primeiro a me incentivar na pesquisa.

À Profa. Dra Maria Cristina Stolf e à Denise Garcia de Santana pela orientação e execução das análises estatísticas.

Aos professores do curso de Pós-Graduação em Fitotecnia (ESALQ/USP), pelos valiosos ensinamentos e colaborações.

À Fundação de Amparo à Pesquisa do Estado de São Paulo (FAPESP) pelo suporte financeiro e bolsa concedida para a realização do projeto.

Ao Clovis Pereira Peixoto e Luis Sanglade Marchiori pelo trabalho em equipe e pelas valiosas sugestões.

A "irmã adotiva" Maria Cristina M. Spinola pela amizade, apoio e incentivo durante todo este tempo de convivência.

A todos os colegas do curso de Pós-Graduação em Fitotecnia, pela amizade e incentivo, em especial a Mariane V. Carvalho, Marcelo H. Miguel, Cleiton S. Perlerbeg, Daniel Gentil, Cristina Maria Ribeiro, Oscar Smiderle, Leila Martins, Renata Maschieto e Maristela Panobianco. 
Aos estagiários da soja, da cana e do girassol: Juliano, Flávia, Gilete, Vanessa, Rodrigo, Patrícia, Lília, Cléa, Daniel, Cristiane e Samanta pelo auxílio nos experimentos.

Aos amigos da "república", Edson Tafuri de Araújo, Claúdio Segateli e Miguel Francisco de Souza Filho, pela amizade sincera.

Aos funcionários de campo do Departamento de Agricultura da ESALQ/USP e da Fazenda Areão, especialmente a Valdinei R. Camargo.

A Helena M. C. P. Chamma e Ana D. C. L. Novembre, pelo auxilio nas avaliações realizadas no Laboratório de Análises de Sementes da ESALQ/USP.

Aos funcionários do Departamento de Agricultura da ESALQ/USP, Adriana Aparecida T. Gimenes, Ilze Helena D. das Neves, Hodair Banzatto, Maria Aparecida Soledade e Celestino Alves Ferreira.

Aos funcionários da biblioteca da ESALQ/USP, especialmente à bibliotecária Eliana Maria Garcia Sabino, pela colaboração na revisão das referências bibliográficas e Maria Cristina Andrade pela elaboração da ficha catalográfica.

A todos que de alguma forma contribuiram para a realização desse trabalho. 


\section{SUMÁRIO}

Página

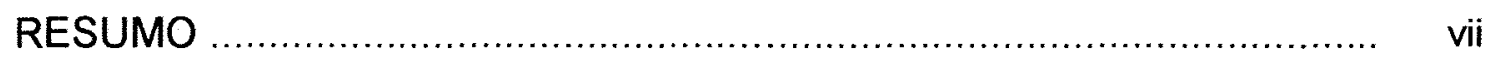

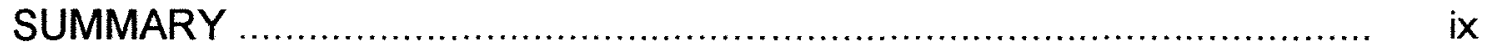

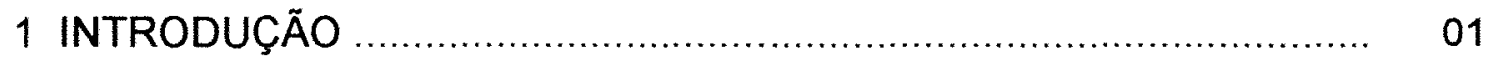

2 REVISÃO DE LITERATURA ................................................... 03

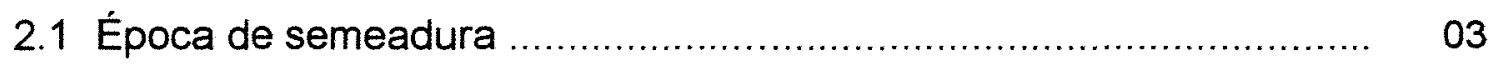

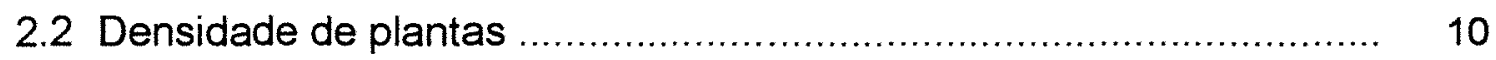

3 MATERIAL E MÉTODOS ......................................................... 15

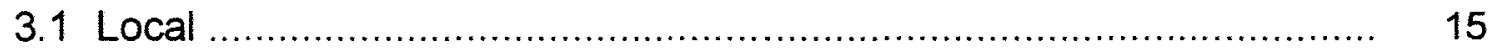

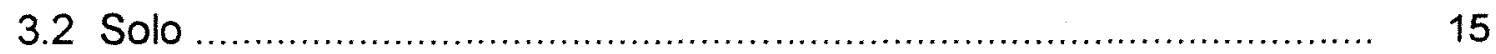

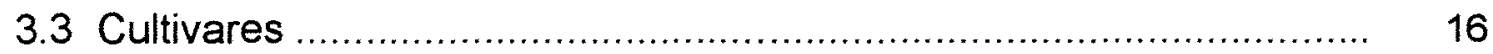

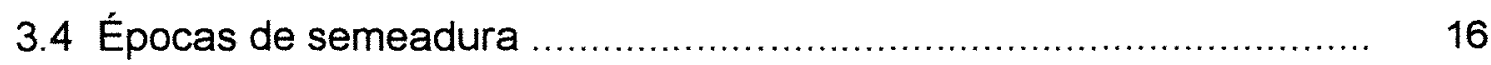

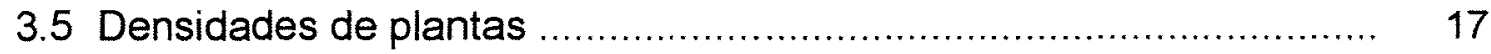

3.6 Preparo da área experimental ............................................ 17

3.7 Instalação dos experimentos ........................................... 18

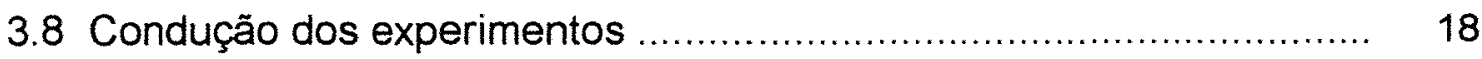

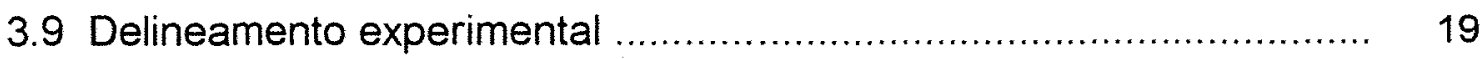

3.10 Acompanhamento fenológico ......................................... 22

3.11 Características avaliadas .............................................. 23

3.11.1 Altura final de planta .................................................. 24

3.11.2 Altura de inserção da primeira vagem ................................. 24

3.11.3 Número de nós ........................................................... 24

3.11.4 Número de ramificações ............................................... 24

3.11.5 Diâmetro da haste principal .......................................... 25

3.11.6 Número de vagens chochas e número diferenciado de grãos por

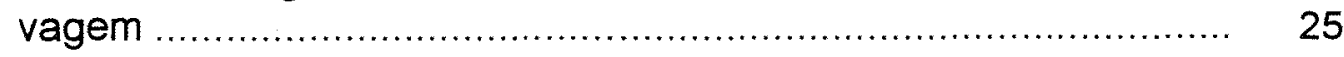

3.11.7 Número total de vagens ........................................... 25 
3.11.8 Número total de grãos ...................................................... 25

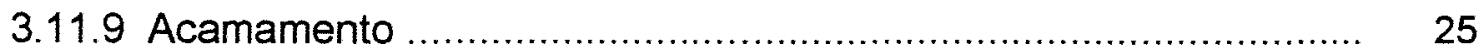

3.11.10 Massa de 1000 grãos ....................................................... 26

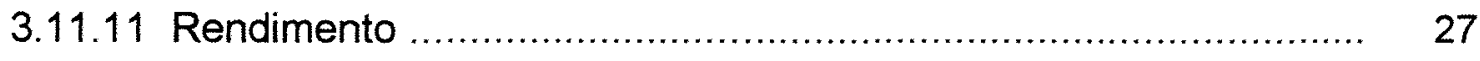

3.12 Clima e desenvolvimento das plantas ........................................ 27

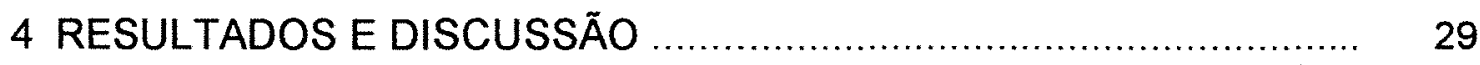

4.1 Acompanhamento fenológico .................................................. 31

4.2 Altura final de planta .............................................................. 32

4.3 Altura de inserção da primeira vagem ........................................... 36

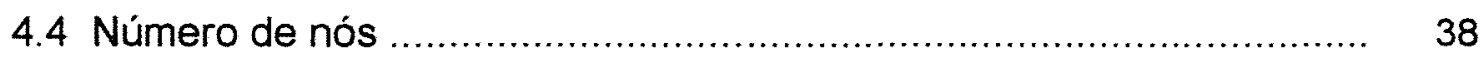

4.5 Número de ramificações ........................................................... 41

4.6 Diâmetro da haste principal ......................................................... 43

4.7 Número de vagens chochas e número diferenciado de grãos por

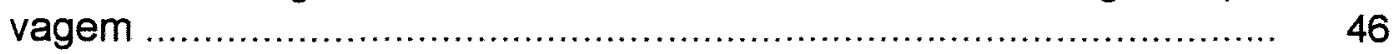

4.7.1 Número de vagens chochas ................................................ 46

4.7.2 Número de vagens com um grão ................................................ 49

4.7.3 Número de vagens com dois grãos ........................................... 50

4.7.4 Número de vagens com três grãos .......................................... 53

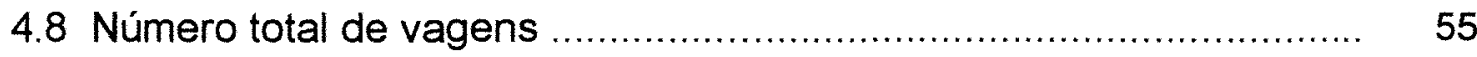

4.9 Número total de grãos ....................................................... 59

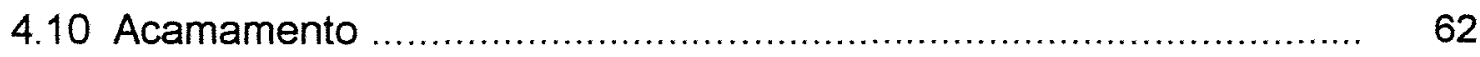

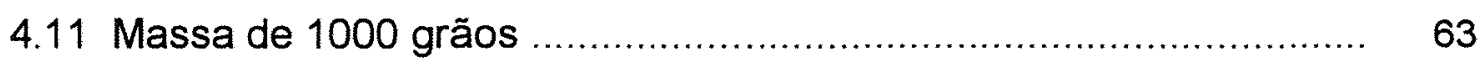

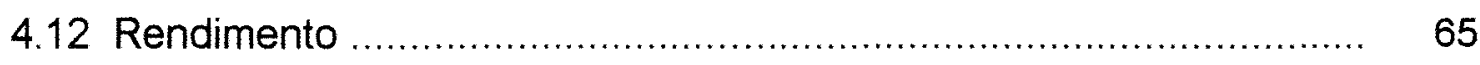

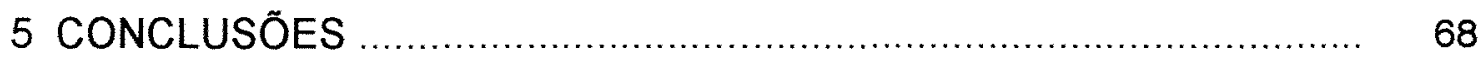

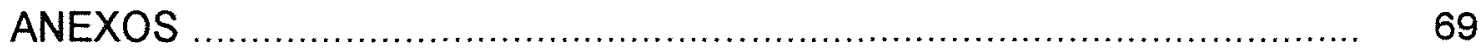

REFERÊNCIAS BIBLIOGRÁFICAS …........................................ 74

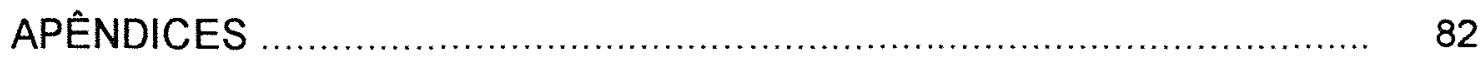




\title{
DESEMPENHO PRODUTIVO DE TRÊS CULTIVARES DE SOJA EM DUAS ÉPOCAS DE SEMEADURA E EM CINCO DENSIDADES DE PLANTAS
}

\author{
Autora: Mônica Cagnin Martins \\ Orientador: Prof. Dr. Gil Miguel de Sousa Câmara
}

\section{RESUMO}

Com o objetivo de avaliar o desempenho produtivo de três cultivares de soja semeados em duas épocas de semeadura sob cinco densidades de plantas, realizou-se esta pesquisa em área experimental da Escola Superior de Agricultura "Luiz de Queiroz", Universidade de São Paulo, em Piracicaba-SP. Avaliou-se os cultivares de soja IAC-17, IAC-12 e IAC-19 com ciclos de maturação precoce, semi precoce e médio, respectivamente, manejados nas densidades de $10,15,20,25$ e 30 plantas. $\mathrm{m}^{-1}$, no espaçamento fixo de 0,50 metros, em épocas de semeadura normal e tardia. Adotou-se o delineamento em blocos ao acaso com 15 tratamentos ( 3 cultivares $\times 5$ populações), repetidos três vezes. Cada parcela foi composta por 5 linhas com 5 metros de comprimento, onde foram avaliadas as seguintes características: altura final de planta, altura de inserção da primeira vagem, número de nós, número de ramificações, diâmetro da haste principal, número de vagens chochas, número de grãos por vagem, número total de vagens, número total de grãos, acamamento, massa de 1000 grãos e rendimento. As principais conclusões são: a) o atraso da época de semeadura nem sempre diminui o rendimento da soja; b) o rendimento de grãos não varia com a densidade de plantas, independentemente das combinações de cultivares e épocas de semeadura; 
c) os cultivares IAC-12 e IAC-19 apresentam melhor desempenho para rendimento em grãos em semeadura normal, independente das densidades; d) os cultivares não apresentam desempenho diferenciado para rendimento de grãos na combinação de época de semeadura tardia com densidade; e) dentre os cultivares, destaca-se o IAC-12 pelo menor chochamento das vagens e pela formação de maior quantidade de vagens contendo três grãos; f) o componente da produção número de grãos por planta é o que mais contribui para a compensação de rendimento. 


\title{
PRODUCTIVE PERFORMANCE OF THREE SOYBEAN CULTIVARS IN TWO SOWING SEASONS AND IN FIVE PLANT DENSITIES
}

\author{
Author: Mônica Cagnin Martins \\ Adviser: Prof. Dr. Gil Miguel de Sousa Câmara
}

\section{SUMMARY}

This research was carried out to evaluate the productive performance of three soybean cultivars in two sowing seasons under five plant densities, at the experimental fields of Escola Superior de Agricultura "Luiz de Queiroz", São Paulo State University, in Piracicaba-SP. The cultivars IAC-17, IAC-12, and IAC-19 with early, semi-early and medium maturation cycles, respectively, were evaluated in planting densities of $10,15,20,25$, and 30 plants. $\mathrm{m}^{-1}$, in a fixed spacing of $0.50 \mathrm{~m}$, and in regular and late sowing seasons. The randomized block in factorial design with 15 treatments ( 3 cultivars $\times 5$ populations), three times repeated was used. Each experimental plot was formed by 5 lines of $5 \mathrm{~m}$ length each, where the following characteristics were evaluated: final plant height, height of the first pod, number of nodes, number of branches per plant, main stem diameter, number of grainless pods, number of grains per pod, total number of pods, total number of grains, lodging, mass of 1,000 grains and yield. The main conclusions are: a) the delay in sowing date, but not always, decreases the soybean yield; b) the grain yield do no vary with plant density independently of cultivars and sowing dates; c) the cultivars IAC-12 and IAC-19 show the best performance for grain yield in regular sowing date, independently of the planting density; d) the yield of the cultivars do not vary with planting 
density in late sowing date; e) IAC-12 presented the smallest number of grainless pods and the largest number of pods with three grains; f) the component of plant production number of grains per plant is the one that most contribute to the yield compensation. 


\section{INTRODUÇÃO}

Atualmente, a cultura da soja (Glycine max (L.) Merrill) constitui-se no agronegócio com maior capacidade de captação anual de divisas internacionais, por meio da exportação do complexo grão-óleo-farelo. Distribuída em cerca de 12 milhões de hectares, a produção nacional da safra $1997 / 98$ foi da ordem de 31 milhões de toneladas de grãos com rendimento médio nacional de $2380 \mathrm{~kg} \cdot \mathrm{ha}^{-1}$.

O rendimento de grãos desta cultura pode variar em função dos fatores climáticos, da intensidade dos danos causados por pragas, doenças e nematóides e das práticas de manejo. Dos aspectos relacionados ao manejo cultural, merece atenção o manejo populacional de cultivares associado às épocas de semeadura de soja.

A época de semeadura é um fator determinante para o sucesso da busca de altas produtividades, alcançadas quando se consegue justapor o desenvolvimento das fases fenológicas da cultura com a presença de ambiente climático favorável à expressão da produtividade do cultivar em uso. De maneira geral, existem épocas adequadas de semeadura para cada cultivar, nas quais a produção é potencialmente maior. Em alguns anos, a semeadura nas datas tidas como ótimas não é praticada devido ao atraso na ocorrência de chuvas, levando os produtores a semearem a soja em épocas mais tardias. Devido ao predomínio de cultivares precoces e semiprecoces, mais sensiveis às variações nas épocas de semeadura, o atraso da instalação da cultura leva a perda de produtividade destes cultivares. 
Juntos, a escolha de cultivares adaptados à região de produção, a semeadura na época adequada e a correspondente população de plantas, têmse constituído em estratégias de manejo para a obtenção de elevadas produtividades.

Anualmente, novos cultivares de soja são lançados no mercado, tornando-se necessário estudá-los quanto ao seu comportamento vegetativo e produtivo, quando submetidos a diferentes épocas e níveis populacionais, pois, alguns novos cultivares de soja tem apresentado excelente desempenho vegetativo em populações abaixo daquela recomendada pela pesquisa, enquanto outros, parecem necessitar maior população para otimizarem sua produtividade.

O presente trabalho teve como objetivo testar as seguintes hipóteses: a) o atraso da época de semeadura concorre para a perda de produtividade da cultura da soja; b) em semeadura tardia, o aumento da densidade de plantas na linha compensa a perda de produtividade da cultura da soja.

Adicionalmente, visa aprimorar o entendimento sobre o manejo varietal e populacional da cultura da soja, por meio da avaliação do desempenho produtivo de três cultivares semeados em época normal e tardia e conduzidos em cinco densidades de plantas. 


\section{REVISÃO DE LITERATURA}

A produtividade de uma cultura é definida pela interação entre a planta, o ambiente de produção e o manejo. Altos rendimentos só são obtidos quando as condições ambientais são favoráveis em todos os estádios de crescimento da soja. Porém, para se obter altos rendimentos, é necessário conhecer práticas culturais compatíveis com produção econômica, aplicadas para maximizar a taxa de acúmulo de matéria seca no grão (Ritchie et al., 1994). Para isto, é importante que o produtor conheça a planta e seus diferentes estádios de desenvolvimento, para que possa avaliar o desempenho da soja e adotar práticas culturais especificas nos estádios em que há maior possibilidade da planta responder favoravelmente (Câmara, 1998a; Câmara, 1998b).

Segundo Ritchie et al. (1994), as principais práticas de manejo que devem ser consideradas são: semeadura na época recomendada para a região de produção; escolha dos cultivares mais adaptados a essa região; uso de espaçamentos e densidades adequados a esses cultivares; monitoramento e controle das plantas daninhas, pragas e doenças e redução ao mínimo das possiveis perdas de colheita.

\section{1 Época de semeadura}

A alta produtividade, além de ser característica genética inerente a cada cultivar, também está alicerçada no sucesso do estabelecimento das plantas no campo, consequência direta da utilização de sementes de boa qualidade e do uso de técnicas culturais adequadas, entre elas, bom preparo do solo, 
semeadura em época apropriada, solo com boa disponibilidade hídrica e boa regulagem da semeadora (França Neto \& Henning, 1984).

A soja, embora originária de uma região de clima temperado, apresenta boa adaptação às condições tropical e subtropical das principais regiões produtoras brasileiras. No entanto, condições que envolvam fatores ambientais como temperatura, precipitação pluvial, umidade relativa do ar, umidade do solo e principalmente, fotoperíodo, influenciam o seu desenvolvimento (Marcos Filho, 1986).

O fotoperíodo é um dos fatores mais importantes a serem considerados na recomendação de cultivares e de épocas de semeadura dentro de uma determinada região, pois, a soja é sensível ao comprimento da noite, para a indução da formação dos botões florais, florescendo quando os dias se tornam mais curtos do que um determinado nível crítico, sendo por isso chamada de "planta de dia curto" (Marcos Filho, 1986; Câmara, 1991).

O fotoperíodo em uma mesma época do ano varia com a latitude ou região, enquanto que em uma mesma latitude, assume valores de acordo com as épocas do ano. Essa variação é maior à medida que se distancia do equador (Câmara, 1991; Urben Filho \& Souza, 1993). Dessa forma, à medida que um cultivar de soja é levado para latitudes menores ou quando a sua semeadura é atrasada, o efeito típico do fotoperíodo é sobre a duração do período de desenvolvimento da planta, compreendido entre a emergência das plântulas e a floração e, consequentemente, sobre a maturação, podendo resultar em plantas mais baixas e menos produtivas (Sediyama et al., 1972; Yuyama, 1979; Marcos Filho, 1986; Câmara, 1991).

Também devido à resposta fotoperiódica, o atraso na época de semeadura em relação a época recomendada, antecipa o florescimento, causando menor desenvolvimento vegetativo, principalmente para os cultivares precoces (Marcos Filho, 1986) e consequentemente, redução na altura final das plantas (Tragnago \& Bonetti, 1984; Marcos Filho, 1986; Marcos Filho \& Novembre, 1990), na altura da primeira vagem (Marcos Filho, 1986; Marcos 
Filho \& Novembre, 1990), no número de nós na planta e no número de vagens por planta (Tragnago \& Bonetti, 1984), resultando em menor produtividade (Nakagawa et al., 1983; Marcos Filho, 1986; Marcos Filho \& Novembre, 1990).

Igualmente importante para a determinação da melhor época de semeadura é a temperatura, a qual está intimamente ligada ao desenvolvimento da planta, exercendo influência sobre todas as fases do ciclo vegetativo. De acordo com Barni \& Bergamaschi (1981), a faixa ótima de temperatura do ar para o desenvolvimento da soja situa-se entre $23^{\circ} \mathrm{C}$ e $25^{\circ} \mathrm{C}$, enquanto que para Marcos Filho (1986), temperaturas de $25^{\circ} \mathrm{C}$ a $30^{\circ} \mathrm{C}$ favorecem a emergência das plântulas, a formação de nódulos e o desenvolvimento das plantas, sendo a de $30^{\circ} \mathrm{C}$ considerada ótima.

A temperatura também influi no rendimento, no porte da planta, na altura de inserção da primeira vagem e outras características da planta de soja (Bergamaschi et al., 1997). Temperaturas baixas podem provocar atrasos nas diferentes fases, enquanto que 0 aumento excessivo pode provocar florescimento precoce, distúrbios na frutificação e acelerar a maturação dos grãos, ocasionando reduções na produção (Marcos Filho, 1986).

Segundo Medina (1994), cultivares precoces de soja semeados no Estado de São Paulo durante os meses de outubro e novembro, desenvolvem seus processos de maturação e colheita sob condições climáticas desfavoráveis, caracterizadas por temperatura e umidade relativa do ar elevadas.

Em relação a precipitação pluvial, Marcos Filho (1986) considera como aptas à cultura da soja, as regiões que apresentem precipitações pluviais de 500 a $700 \mathrm{~mm}$ durante o ciclo das plantas.

Períodos longos de excesso ou deficiência hídrica, durante os estádios fenológicos da planta correspondentes à germinação-emergência, floração e enchimento dos grãos, reduzem significativamente o rendimento da soja. Nestes casos, como estratégia de manejo que visa minimizar os prejuizos, 
ajusta-se a época de semeadura (Barni \& Bergamaschi, 1981; Urben Filho \& Souza, 1993).

Segundo Marcos Filho (1986), deficiências hídricas em qualquer dos estádios reprodutivos é prejudicial à produção. Durante o período de início de formação das vagens há prejuízo em função da maior intensidade de abortos, acarretando menor número de sementes com tamanho normal. Quando as plantas estão em fase de acúmulo intenso de matéria seca, embora o número de sementes não seja reduzido, o seu peso será seriamente prejudicado.

Nenhuma prática cultural isolada é mais importante para a soja do que a época de semeadura, sendo a variável que produz maior impacto sobre a produção da cultura (Bueno et al.,1975; Barni \& Bergamaschi, 1981; Nakagawa et al., 1983; Rocha et al., 1984). A melhor época de semeadura para a soja depende, principalmente, da temperatura do solo para a germinação, da temperatura do ar durante todo o ciclo da planta, do fotoperíodo após a emergência e da umidade do solo na semeadura, na floração, na maturação e na colheita (Barni \& Bergamaschi, 1981).

Para as condições brasileiras, a época de semeadura da cultura da soja varia em função do cultivar, região de cultivo e condições climáticas do ano agrícola, geralmente apresentando como faixa de recomendação o período de outubro à dezembro (Nakagawa et al., 1983). De acordo com estes autores, o mês de novembro tem proporcionado os melhores resultados nos estados que cultivam mais tradicionalmente esta cultura.

Para indicar o melhor período de semeadura para cada cultivar de soja, é importante a obtenção de dados referentes ao desempenho agronômico dos genótipos em diferentes épocas de semeadura (Carraro et al., 1984), pois, temse verificado que a época de semeadura pode afetar diferentes componentes da produção, como: número de vagens por planta (Tragnago \& Bonetti, 1984); número de sementes por vagem e peso da semente (Milanez et al., 1978).

Nogueira et al. (1984) estudando os efeitos da época de semeadura antecipada, normal e tardia sobre a produção de soja e de seus componentes, 
semearam os cultivares UFV-1 e IAC-7 em oito épocas (de outubro a março) na região de Campinas-SP e verificaram que a época de semeadura afetou o peso das sementes, sendo que a produção diminuiu progressivamente com o atraso da semeadura. Constataram que o número de nós e de vagens por planta é mais afetado pela época de semeadura do que o peso da semente, levando-os a conclusão de que essas duas características são mais importantes na produção da cultura do que o peso da semente.

Além dos componentes da produção, a época de semeadura provoca alterações nas características agronômicas da soja, como altura de planta, altura de inserção da primeira vagem, número de ramificações, diâmetro do caule e acamamento (Empresa Brasileira de Pesquisa Agropecuária EMBRAPA, 1996).

Apesar de ser uma característica determinada pelo genótipo, a altura da planta também é influenciada pela época de semeadura, população de plantas, condições de temperatura, umidade e luminosidade e pelas propriedades físicas e químicas do solo (Marcos Filho, 1986).

Vários autores verificaram redução na altura das plantas de soja devido a menor duração do período vegetativo, relacionada a atrasos na semeadura (Sediyama et al., 1972; Yuyama, 1979; Tragnago \& Bonetti, 1984; Marcos Filho, 1986; Câmara, 1991).

Bhéring (1989), estudando o desempenho agronômico e a qualidade fisiológica das sementes de 12 genótipos e alguns cultivares de soja, conduzidos em quatro épocas de semeadura, na região de Florestal-MG, observou que o número de dias para a floração e a maturação e o ciclo da cultura reduziram, à medida que atrasou a semeadura; nas diferentes épocas de semeadura, as alturas de planta e de inserção da primeira vagem foram, em geral, satisfatórias à colheita mecanizada; as semeaduras realizadas mais cedo proporcionaram maior altura de planta e maior rendimento de grãos. Todavia, sementes de melhor qualidade, para a maioria dos genótipos estudados, foram 
produzidas nas épocas mais tardias, correspondentes ao final de novembro e início de dezembro.

A altura de inserção da primeira vagem sendo responsável pelas menores ou maiores perdas durante a operação de colheita mecânica, é outra característica agronômica que reflete diretamente na produção de grãos de soja (Yuyama, 1979). De acordo com Marcos Filho (1986), para se evitar maiores perdas na colheita decorrentes de vagens não colhidas pela colhedora, a altura de inserção das primeiras vagens, deve ser superior a $13 \mathrm{~cm}$.

De modo geral, semeaduras realizadas a partir de dezembro podem provocar o florescimento antecipado, principalmente dos cultivares precoces, menor desenvolvimento vegetativo $e$, consequentemente, redução da altura de plantas, da altura de inserção das primeiras vagens e da produção de grãos. Entretanto, Yuyama (1979) verificou aumento gradativo na altura de inserção da primeira vagem com o atraso da época de semeadura.

O número de vagens por planta está relacionada com o ciclo da planta, sendo que esta regula a sua produção em função das condições ambientais durante o seu ciclo de desenvolvimento (Yuyama, 1979).

O acamamento pode refletir na produtividade da soja, pois, dificulta a colheita e favorece o aparecimento de doenças no campo, danificando as sementes (Nakagawa et al., 1983). Neste sentido, Melfi (1996) em Viçosa-MG, com o objetivo de avaliar o efeito do acamamento na produtividade e qualidade fisiológica e sanitária de sementes de soja do cultivar IAC-8, submeteu este cultivar a cinco niveis de acamamento $\left(0 ; 22,5 ; 45 ; 67,5\right.$ e $90^{\circ}$ em relação à vertical) em três estádios fenológicos $\left(R_{2}, R_{4}\right.$ e $\left.R_{6}\right)$ e duas épocas de colheita $\left(R_{8}\right.$ e $R_{8}+30$ dias). Com base nos resultados, conclui que a produção decresce com o aumento dos niveis de acamamento; a qualidade fisiológica é menor quanto mais precoce for o acamamento, maior o retardamento da colheita $e$ maior o nível de acamamento; o retardamento de colheita e os niveis crescentes de acamamento reduzem proporcionalmente a qualidade sanitária 
das sementes e quanto maior o retardamento da colheita e maior o nível de acamamento, menor a qualidade sanitária das sementes de soja.

O peso da semente, expresso pelo peso de 100 sementes, encontra-se sobre controle genético (Hartwig, 1973), mas, também é afetado pelas condições ambientais ocorridas durante o desenvolvimento da semente, como observado por Nakagawa et al. (1991). Estes pesquisadores estudaram durante três anos agrícolas em Botucatu-SP, os efeitos de seis épocas de semeadura sobre a proporção de sementes de diferentes tamanhos e sobre o peso de 100 sementes dos cultivares de soja Santa Rosa, UFV-1 e Paraná e concluíram que as porcentagens de sementes maiores e os pesos de 100 sementes, para cada cultivar, diminuíram tanto com a antecipação como, principalmente, com o retardamento da semeadura. Contudo, também há relatos de aumento de peso de sementes com o atraso na semeadura (Milanez et al., 1978).

Melhorança \& Mesquita (1982) procuraram determinar o efeito dos fatores épocas de semeadura, cultivares e espaçamento, sobre o rendimento de grãos e características agronômicas dos cultivares de soja Paraná (precoce), Santa Rosa (semi tardia) e UFV-1 (tardia), em três espaçamentos (40, 60 e 80 $\mathrm{cm}$ ) e na densidade de 40 plantas $\mathrm{m}^{-1}$, quando semeados em 15/out, 15/nov e 15/dez, em Dourados-MS. Concluíram que não houve variação no rendimento de grãos dos três cultivares de soja em função dos espaçamentos usados; as épocas 15/out e 15/nov propiciaram os maiores rendimentos; a duração dos períodos de desenvolvimento da soja (da emergência à floração e da emergência à maturação) não foi alterada pelos espaçamentos, no entanto, houve sensivel redução destes períodos à medida que se sucederam as épocas de semeadura; as características agronômicas de altura final de planta e altura de inserção da primeira vagem não foram afetadas pelos espaçamentos e foram compativeis para a colheita mecânica em qualquer época e espaçamento. 


\subsection{Densidade de plantas}

A combinação da densidade de plantas na linha de semeadura com o espaçamento entre linhas definem a população de plantas da cultura, a qual influencia algumas características agronômicas da planta de soja (Urben Filho \& Souza, 1993), bem como, pode modificar a produção de grãos (Lam-Sanchez \& Veloso, 1974a).

A melhor população de plantas, de acordo com Val et al. (1971), Gaudêncio et al. (1990) e EMBRAPA (1996), depende da região, da época de semeadura e do cultivar. Vários estudos têm demonstrado que a melhor população de plantas de soja para o sistema convencional de plantio é de aproximadamente 400.000 plantas. $^{-1} \mathrm{a}^{-1}$, havendo tolerância da cultura para variações da ordem de $20 \%$ a $25 \%$ deste número para mais ou para menos. Esta mesma população de plantas pode ser indicada para o sistema de plantio direto, pois Gaudêncio et al. (1990) realizando experimentos em GuarapuavaPR, durante três anos consecutivos, verificaram que os cultivares de soja Bragg e Paraná não reduziram o rendimento quando se utilizou populações de 280.000 plantas. ha ${ }^{-1}$ até 650.000 plantas. ha $^{-1}$. No entanto, em áreas favoráveis ao acamamento, estes autores sugerem que esta população de plantas seja diminuída.

A população é fator determinante para o arranjo das plantas no ambiente de produção e influencia o crescimento da soja. Dessa forma, a melhor população de plantas deve possibilitar além do alto rendimento, altura de planta e de inserção de primeira vagem adequada a colheita mecanizada e plantas que não acamem (Reis et al., 1977; Gaudêncio et al., 1990). Estas características agronômicas são influenciadas pelo espaçamento e densidade de semeadura, como comprovado em vários trabalhos (Lam-Sanchez \& Veloso, 1974a; Lam-Sanchez \& Veloso, 1974b; Reis et al., 1977; Rosolem et al., 1983; Nakagawa et al., 1986a; Nakagawa et al., 1986b; Nakagawa et al., 1987). 
Lam-Sanchez \& Veloso (1974a) com o objetivo de verificar o efeito do espaçamento e da densidade de plantas sobre várias características agronômicas na cultura da soja, semearam em Jaboticabal-SP o cultivar Viçoja em época tardia ( 10 e 11 de dezembro), combinando os espaçamentos de 50 , 60,70 e $80 \mathrm{~cm}$ entre linhas e as densidades de 10,20,30 e 40 plantas. $\mathrm{m}^{-1}$, de forma a obter diversas populações de plantas. Estes autores concluíram que a densidade influenciou positivamente a altura de planta e a inserção da primeira vagem e, negativamente, o diâmetro e o número de vagens por planta. Resultados semelhantes foram observados em cultivares de soja semeados tardiamente em Botucatu-SP, por Nakagawa et al. (1986b) e Nakagawa et al. (1987).

Rosolem et al. (1983) conduziram experimento em Paranapanema - SP com o objetivo de estudar os efeitos de densidades de plantas, niveis de adubação e épocas de semeadura sobre a produção e seus componentes na cultura da soja. Semearam o cultivar UFV-1 no dia 12/12, nas densidades de $10,20,30$ e 40 plantas. $\mathrm{m}^{-1}$ e no espaçamento fixo de $0,40 \mathrm{~m}$, sendo os niveis de adubação com 100, 200, 300 e $400 \mathrm{~kg}$ ha $^{-1}$ da fórmula 00-33-12. Os autores verificaram que $o$ aumento na densidade de plantas na linha provocou aumento significativo na altura de planta e diminuição da produção por planta, do número de ramos por planta e da produtividade. A redução no número de ramos em função do aumento da densidade de plantas, provavelmente ocorreu como consequência do encurtamento do ciclo do cultivar, observado na semeadura em dezembro.

De acordo com Hinson \& Hanson (1962) as ramificações são produzidas a partir das gemas axilares, que são reguladas pela gema apical, cuja atividade diminui com o fotoperíodo, tendo como consequência, a redução do número de ramificações em semeaduras mais tardias. O maior número de ramificações formadas por planta quando se aumenta a densidade de plantas na linha, também foi observado em experimentos realizados por Nakagawa et al. (1986a), Nakagawa et al. (1986b) e Nakagawa et al. (1987). 
Alguns agricultores utilizam altas densidades de semeadura de soja, por proporcionarem rápida emergência de plântulas e favorecerem o controle das plantas daninhas. Porém, o excesso de plantas, mesmo que não cause redução no rendimento, modifica a arquitetura e o aproveitamento de luz, deixando-as mais sujeitas ao acamamento (Gaudêncio et al., 1990).

Visando avaliar os efeitos do espaçamento e da densidade de plantio sobre o cultivar de soja UFV-1, Reis et al. (1977) conduziram durante dois anos agrícolas, dois experimentos na região do Triângulo Mineiro. Semearam a soja em $28 / 11$ e 07/12, nas densidades de $20,25,30$ e 35 plantas. $m^{-1}$ e nos espaçamentos entre linhas de $50,60,70$ e $80 \mathrm{~cm}$ em dois solos diferentes quanto à fertilidade, ou seja, em Latossolo Roxo franco-argiloso (solo fértil) e Latossolo Roxo transição para Latossolo Vermelho-Escuro (solo menos fértil). Concluíram que, independente da fertilidade do solo, a altura de planta e o estande final diminuíram proporcionalmente ao aumento da densidade de plantas na linha e que o grau de acamamento aumentou com a redução do espaçamento e com o aumento da densidade, enquanto que não houve efeito significativo dos espaçamentos e das densidades na produção de sementes.

Além das características agronômicas da soja, o espaçamento e a densidade também podem influenciar o rendimento final. Porém, na maioria dos trabalhos revisados, verifica-se que a cultura da soja é muito pouco afetada por variações na densidade de plantas na linha de semeadura, pois, a planta possui capacidade de ajustar os componentes da produção, como comprovado por Cartter \& Hartwig (1967).

Lam-Sanchez \& Veloso (1974b) observaram que o maior e o menor

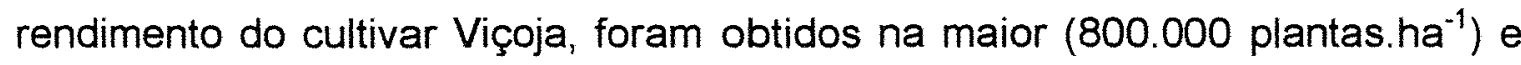
na menor população de plantas (125.000 plantas.ha ${ }^{-1}$ ), respectivamente. O cultivar Paraná quando semeado em populações menores que 280.000 plantas. ha ${ }^{-1}$, apresentou redução no rendimento (Gaudêncio et al., 1990).

Por outro lado, Bueno et al. (1975) estudando o desempenho de dois cultivares tardios de soja em três épocas de semeadura, dois espaçamentos e 
três densidades de plantio, observaram que o espaçamento de $0,60 \mathrm{~m}$ e a densidade de 10 plantas. $\mathrm{m}^{-1}$ (aproximadamente 165.000 plantas.ha ${ }^{-1}$ ), apresentaram melhores resultados sem prejuízos à produção e com menor gasto de sementes.

Visando estudar os efeitos da densidade de plantas e da época de semeadura na produção e qualidade de sementes de soja, Nakagawa et al. (1988) conduziram dois experimentos em Botucatu-SP, com os cultivares IAC-Foscarin-31 (precoce), IAC-8 (média) e IAC-9 (semi tardia), nas densidades de 10,20 e 30 plantas. $\mathrm{m}^{-1}$ e espaçamento entre linhas de $0,60 \mathrm{~m}$, em duas épocas de semeadura: novembro e dezembro. Com base nos resultados, concluíram que a produção dos três cultivares na época de semeadura normal não foi afetada pela densidade, devido a um ajuste dos componentes da produção, de tal forma que o número de plantas pode ser compensado pela maior produção por planta (Cartter \& Hartwig, 1967). Entretanto, nas semeaduras de dezembro, o cultivar IAC-Foscarin-31 apresentou menor rendimento na menor densidade em um dos experimentos e em outro, verificouse a maior produção do IAC-9, na maior densidade. Além disso, a qualidade de sementes foi mais afetada pela época de semeadura, sendo que as realizadas em dezembro propiciaram melhores qualidades.

Em outro trabalho, Nakagawa et al. (1987) verificaram que os cultivares de soja Paraná, Santa Rosa e UFV-1, quando semeados no dia 23/12, apresentaram os maiores rendimentos na maior densidade ( 30 plantas. $\mathrm{m}^{-1}$ ), pois o maior número de plantas por unidade de área compensou a menor produção por planta.

Esta compensação nem sempre acontece, pois Rosolem et al. (1983), verificaram que a medida em que aumentou a densidade de plantas na linha, obteve decréscimos na produção de grãos e a maior população não foi suficiente para compensar a menor produção por planta, resultando em queda na produtividade. 
Outro componente da produção da planta de soja é a massa média da semente de cada cultivar, a qual varia com a época de semeadura, local e ano agrícola, porém, é pouco influenciada pelo manejo cultural. Neste sentido, Val et al. (1971) estudando dois cultivares de soja semeados nas densidades de 8 , 16, 24 e 31 plantas. $\mathrm{m}^{-1}$ e espaçadas em 25, 50, 75 e $100 \mathrm{~cm}$, em Capinópolis e Sete Lagoas, regiōes de Minas Gerais, verificaram que a massa da semente foi maior com o aumento do espaçamento, porém, não foi influenciada pela densidade de plantas na linha.

Contrapondo esses resultados, Nakagawa et al. (1986a) verificaram que na menor densidade de plantas na linha, os cultivares de soja IAC-Foscarin-31, IAC-8 e IAC-9, produziram sementes de maior massa. O mesmo foi observado por Nakagawa et al. (1987) nos cultivares de soja Paraná, Santa Rosa e UFV-1, em semeaduras realizadas em dezembro. Burris (1973) verificou aumento na massa de 100 sementes quando se aumentava a densidade de 13,3 plantas. $\mathrm{m}^{-1}$ para 26,6 plantas. $\mathrm{m}^{-1}$.

Entretanto, em vários trabalhos foi constatado que o componente da produção que mais afeta o rendimento de grãos é o número de vagens por planta (Gilioli et al., 1979; Rosolem et al., 1983; Nakagawa et al., 1988). 


\section{MATERIAL E MÉTODOS}

\subsection{Local}

O trabalho foi realizado em área experimental da Escola Superior de Agricultura "Luiz de Queiroz", Universidade de São Paulo (ESALQ/USP), no município de Piracicaba-SP, localizada a $22^{\circ} 41^{\prime} 30^{\prime \prime}$ de latitude Sul, $47^{\circ} 38^{\prime} 30^{\prime \prime}$ de longitude Oeste e $546 \mathrm{~m}$ de altitude, durante o ano agrícola 1996/97.

\subsection{Solo}

O experimento foi conduzido em solo Podzólico Vermelho Escuro, profundo, com boa drenagem e textura muito argilosa, contendo $62 \%$ de argila total, $11 \%$ de silte e $27 \%$ de areia, cuja composição química determinada por análise química do solo, fundamentada em amostras compostas, pode ser observada na Tabela 1.

Tabela 1. Composição química do solo da área experimental.

\begin{tabular}{|c|c|c|c|c|c|c|c|c|c|c|c|}
\hline \multirow{2}{*}{$\begin{array}{l}\text { Prof. }^{1} \\
\text { (cm) }\end{array}$} & \multirow{2}{*}{$\begin{array}{c}\mathrm{pH} \\
\left(\mathrm{CaCl}_{2}\right)\end{array}$} & \multirow{2}{*}{$\begin{array}{l}\text { M.O. } \\
\left(\mathrm{g} . \mathrm{dm}^{-3}\right)\end{array}$} & \multirow{2}{*}{$\begin{array}{c}\mathrm{P} \\
\left(\mathrm{mg} \cdot \mathrm{dm}^{-3}\right)\end{array}$} & $\bar{K}$ & $\overline{\mathrm{Ca}}$ & $\mathrm{Mg}$ & $\mathrm{Al}$ & $\mathrm{H}+\mathrm{Al}$ & $S B$ & $\bar{T}$ & \multirow{2}{*}{$\begin{array}{l}\mathrm{V} \\
(\%)\end{array}$} \\
\hline & & & & \multicolumn{7}{|c|}{$\left(\mathrm{mmol}_{\mathrm{c}} \cdot \mathrm{dm}^{-3}\right)$} & \\
\hline $00-20$ & 4,4 & 24 & 4,0 & 2,6 & 32 & 14 & 3,0 & 72 & 49 & 121 & 40 \\
\hline $20-40$ & 4,2 & 20 & 4,0 & 1,5 & 20 & 8,0 & 8,0 & 72 & 30 & 102 & 29 \\
\hline
\end{tabular}

Trofundidade de amostragem do solo. 


\subsection{Cultivares}

Foram utilizados os cultivares IAC-17, IAC-12 e IAC-19, recomendados para as regiões produtoras de soja do Estado de São Paulo, cujas principais características são apresentadas na Tabela 2.

Tabela 2. Principais características dos cultivares de soja IAC-17, IAC-12 e IAC-19.

\begin{tabular}{lccc}
\hline \multirow{2}{*}{ Características } & \multicolumn{3}{c}{ Cultivares } \\
\cline { 2 - 4 } & IAC-17 & IAC-12 & IAC-19 \\
\hline Ciclo (dias) & $100-120$ & $120-125$ & $125-130$ \\
Ciclo (classificação) & Precoce & Semi precoce & Médio \\
Floração (dias) & $30-40$ & $30-40$ & $40-50$ \\
Altura de planta (cm) & 80 & 80 & 90 \\
Hábito de crescimento & Determinado & Determinado & Determinado \\
Massa de 1000 grãos (g) & 140 & 145 & 160 \\
Época de semeadura recomendada & Out/Nov & Out/Nov & Out/Nov \\
Reação ao cancro da haste & Resistente & Resistente & Resistente \\
Reação ao Meloydogine javanica & Resistente & Suscetivel & Resistente \\
Reação a Meloydogine incognita & Resistente & Resistente & Resistente \\
\hline
\end{tabular}

Fonte: Sementes Brejeiro s.d.; Dedini Sementes ${ }^{2}$ s.d.

\section{4 Épocas de semeadura}

Foram estudadas duas épocas de semeadura em relação à cultura da soja no Estado de São Paulo.

A primeira época, correspondente à época normal de semeadura da soja nesse Estado, foi efetivada no dia 12/11/1996, enquanto a segunda época, considerada como tardia, foi instalada no dia 19/12/1996.

\footnotetext{
${ }^{1}$ CULTURA da soja. Orlândia: Sementes Brejeiro. Produtos Alimentícios Orlândia. s.d.

${ }^{2}$ SEMENTES de soja: colhe mais quem escolhe DEDINI. Pirassununga: Sementes Dedini. s.d.
} 


\subsection{Densidades de plantas}

Para evitar a interferência do espaçamento entre linhas, este foi fixado em $0,50 \mathrm{~m}$ para todas as parcelas, de maneira que a variação populacional foi consequência da condução de diferentes densidades de plantas na linha, conforme se observa na Tabela 3.

Tabela 3. Variação populacional da soja em função de diferentes densidades de plantas na linha.

\begin{tabular}{ccc}
\hline $\begin{array}{c}\text { Espaçamento entrelinhas } \\
(\mathrm{m})\end{array}$ & $\begin{array}{c}\text { Densidades } \\
\left(\text { plantas. } \mathrm{m}^{-1}\right)\end{array}$ & $\begin{array}{c}\text { Populaçōes } \\
\left.\text { (plantas.ha }{ }^{-1}\right)\end{array}$ \\
\hline 0,50 & 10 & 200.000 \\
0,50 & 15 & 300.000 \\
0,50 & 20 & 400.000 \\
0,50 & 25 & 500.000 \\
0,50 & 30 & 600.000 \\
\hline
\end{tabular}

A fim de se obter estandes iniciais acima dos valores desejados, o número de sementes distribuído por parcela foi acrescido em $50 \%$. Aos 14 dias após a emergência, realizou-se o desbaste do excesso de plantas de soja na linha de semeadura, para atingir as densidades e populações propostas e apresentadas na Tabela 3.

\subsection{Preparo da área experimental}

O solo foi preparado de maneira convencional através de uma aração, aproveitando-se para a incorporação da metade da dose de calcário, seguida de uma gradeação, quando foi incorporada a segunda metade da dose de calcário. Simultaneamente, realizou-se o primeiro nivelamento do terreno. O segundo nivelamento foi realizado junto com a incorporação dos herbicidas 
trifluralina e imazaquin nas doses dos produtos comerciais equivalentes a 2,0 L.ha ${ }^{-1}$ e 1,0 L.ha ${ }^{-1}$, respectivamente.

\subsection{Instalação dos experimentos}

Visando a proteção das sementes de soja no início de seu desenvolvimento (germinação-emergência) contra a ação do complexo de fungos do solo, estas foram tratadas com o fungicida Carboxin + Thiram na dose do produto comercial equivalente a $280 \mathrm{ml} .100 \mathrm{~kg}^{-1}$ de sementes.

Para calagem da área experimental utilizou-se calcário dolomítico com $80 \%$ de PRNT, aplicado na dose equivalente a 2,0 toneladas por hectare. A adubação de base foi fundamentada na análise química do solo (Tabela 1) e na expectativa para rendimento esperado da ordem de $2500 \mathrm{~kg}$ a $3000 \mathrm{~kg}$ de grãos.ha-1. Aplicou-se o equivalente a $400 \mathrm{~kg}^{-h a^{-1}}$ da fórmula fertilizante 00-20-15, correspondendo à recomendação por hectare de $80 \mathrm{~kg}$ de $\mathrm{P}_{2} \mathrm{O}_{5}$ e $60 \mathrm{~kg}$ de $\mathrm{K}_{2} \mathrm{O}$, proposta por Mascarenhas \& Tanaka (1996).

Quanto ao nitrogênio, previamente à semeadura, providenciou-se a inoculação das sementes dos cultivares de soja com inoculante turfoso, na dose de $0,6 \mathrm{~kg} .40 \mathrm{~kg}^{-1}$ de sementes. Após essa operação, as sementes foram distribuídas manualmente nas parcelas.

\subsection{Condução dos experimentos}

As plantas daninhas não controladas pelos herbicidas, foram retiradas por meio de capinas com enxadas.

A população de pragas foi monitorada através da técnica do "pano de batida". Não houve incidência de lagartas desfolhadoras, enquanto a ocorrência do complexo de percevejos, constituído especialmente por Nezara viridula, Piezodorus guildinii e Euchistos heros, foi frequente na área. Neste caso, adotou-se como nível de controle para os percevejos, a presença de dois 
insetos por pano de batida, de acordo com a recomendação proposta por Panizzi (1990) para lavoura de sementes.

Para o controle do complexo de percevejos, pulverizou-se o inseticida Endosulfan na dose do produto comercial equivalente a 0,65 L.ha $a^{-1}+0,5 \%$ de $\mathrm{NaCl}$. Neste caso, o sal de cozinha foi usado para aumentar a eficiência do inseticida químico (Corso, 1988; Sosa-Gómez et al., 1993).

A irrigação das parcelas, quando necessária, foi realizada para permitir a emergência das plântulas e garantir o pleno desenvolvimento da cultura.

\subsection{Delineamento experimental}

Foram conduzidos dois experimentos individuais $e$ independentes, de maneira que, à cada época de semeadura correspondeu o delineamento experimental em blocos casualizados em esquema fatorial $3 \times 5$ (três cultivares: IAC-17, IAC-12 e IAC-19 e cinco densidades de plantas: 10, 15, 20, 25 e 30 plantas. $\mathrm{m}^{-1}$ ) com três repetições.

Cada unidade experimental foi constituída por cinco linhas de $5,0 \mathrm{~m}$ de comprimento, sendo as duas linhas externas consideradas como bordaduras. Como área útil foram utilizadas as três linhas centrais, sendo eliminados, a título de bordadura, 0,50 $\mathrm{m}$ de cada extremidade.

Todos os dados coletados na área útil de cada repetição para as diferentes variáveis foram analisados estatisticamente, por meio da análise da variância. Os efeitos estatisticamente significativos pelo teste $F$ foram analisados pelo teste de Tukey, visando a comparação entre cultivares. Quando - objetivo foi estudar as diferentes densidades, utilizou-se a análise de regressão polinomial.

Os dados de contagem que não apresentaram distribuição normal e/ou variâncias homogêneas, foram transformados pela extração da raiz quadrada.

Visando-se compreender como as épocas interagiram com os fatores, promoveu-se a análise da variância conjunta das mesmas, desde que, para 
cada variável analisada, a relação entre o maior e o menor quadrado médio do resíduo não fosse superior a 8,0 (Snedecor \& Cochran, 1989).

Os esquemas das análises das variâncias dentro de época e conjunta entre as épocas são apresentadas nas Tabelas 4 e 5, respectivamente.

Tabela 4. Esquema da análise da variância individual.

\begin{tabular}{lc}
\hline Fontes da variação & Graus de liberdade \\
\hline Bloco & 2 \\
Cultivar (C) & 2 \\
Densidade (D) & 4 \\
Interação C * D & 8 \\
Resíduo & 28 \\
\hline Total & 44 \\
\hline
\end{tabular}

Tabela 5. Esquema da análise da variância conjunta.

\begin{tabular}{lc}
\hline Fontes da variação & Graus de liberdade \\
\hline Bloco d. época & 4 \\
Época (E) & 1 \\
Cultivar (C) & 2 \\
Densidade (D) & 4 \\
Interação E * C & 2 \\
Interação E * D & 4 \\
Interação C * D & 8 \\
Interação E * C ${ }^{*}$ D & 8 \\
Resíduo & 56 \\
\hline Total & 89 \\
\hline
\end{tabular}

O modelo matemático utilizado para as análises individuais é apresentado a seguir: 
$y_{i j k}=\mu+\alpha_{i}+\beta_{i}+\gamma_{i j}+\delta_{k}+e_{i j k}$

Em que:

$i=1,2,3 \quad j=1,2,3,4,5 \quad k=1,2,3$

$\mu$ : constante do modelo;

$\alpha_{i}$ : efeito do $i$ - ésimo cultivar;

$\beta_{\mathrm{f}}$ : efeito da $\mathrm{i}$ - ésima densidade;

$\gamma_{i j}$ : efeito da interação cultivar com densidade;

$\delta_{k}$ : efeito do $k$ - ésimo bloco;

$e_{\mathrm{ijk}}$ : erro experimental não observável, tal que $e_{\mathrm{ijk}} \cap \mathrm{N}\left(0, \sigma^{2}\right)$.

Para as análises conjuntas, o modelo matemático é:

$y_{i j k}: \mu+\alpha_{i}+\beta_{j(i)}+\gamma_{k}+\delta_{l}+(\alpha \gamma)_{i k}+(\alpha \delta)_{i l}+(\gamma \delta)_{k l}+(\alpha \gamma \delta)_{i k l}+e_{i j k l}$

\section{Em que:}

$i=1,2 \quad j=1,2,3 \quad k=1,2,3 \quad l=1,2,3,4,5$

$\mu$ : constante referente ao modelo;

$\alpha_{i}$ : efeito da i - ésima época;

$\beta_{\mathrm{j}(i)}$ : efeito da j - ésimo bloco dentro da i - ésima época;

$\gamma_{\mathrm{k}}$ : efeito do $\mathrm{k}$ - ésimo cultivar;

$\delta_{l}$ : efeito da e - ésima densidade;

$(\alpha \gamma)_{\text {ik }}$ : efeito da interação época com cultivar;

$(\alpha \delta)_{\mathrm{il}}$ : efeito da interação época com densidade;

$(\gamma \delta)_{\mathrm{kl}}$ : efeito da interação cultivar com densidade;

$(\alpha \gamma \delta)_{\mathrm{kl} 1}$ : efeito da interação entre época, cultivar e densidade;

$e_{i \mathrm{jkl}}$ : erro experimental, não observável, tal que $e_{\mathrm{ijkl}} \cap \mathrm{N}\left(0, \sigma^{2}\right)$. 


\subsection{Acompanhamento fenológico}

Acompanhou-se o desenvolvimento fenológico dos cultivares de soja em cada época de semeadura, seguindo-se a Escala Fenológica de Fehr \& Caviness (1977), observando-se os estádios fenológicos apresentados nas Tabelas 6 e 7. As observações fenológicas foram realizadas em amostras constituídas de 10 plantas ao acaso por parcela, anotando-se a data de ocorrência de cada estádio.

Tabela 6. Descrição dos estádios vegetativos da soja.

\begin{tabular}{|c|c|c|}
\hline Símbolo & Denominação & Descrição \\
\hline VE & Emergência & Os cotilédones estão acima da superficie do solo. \\
\hline VC & Cotilédone desenvolvido & $\begin{array}{l}\text { Os cotilédones apresentam-se bem abertos e as } \\
\text { folhas unifolioladas estão suficientemente abertas, } \\
\text { de tal modo que os bordos de cada unifólio não } \\
\text { estão se tocando. }\end{array}$ \\
\hline$V_{1}$ & Primeiro nó maduro & $\begin{array}{l}\text { As folhas unifolioladas estão estendidas e a } \\
\text { primeira folha trifoliolada está suficientemente } \\
\text { aberta, de tal modo que os bordos de cada foliolo } \\
\text { não estão se tocando. }\end{array}$ \\
\hline$V_{2}$ & Segundo nó maduro & $\begin{array}{l}\text { A primeira folha trifoliolada está estendida, isto é, } \\
\text { com os três folíolos expandidos e a segunda folha } \\
\text { trifoliolada está suficientemente aberta, de tal modo } \\
\text { que os bordos de cada folíolo não estão se } \\
\text { tocando. }\end{array}$ \\
\hline$V_{3}$ & Terceiro nó maduro & $\begin{array}{l}\text { A segunda folha trifoliolada está estendida, isto é, } \\
\text { com os três foliolos expandidos e a terceira folha } \\
\text { trifoliolada está suficientemente aberta, de tal modo } \\
\text { que os bordos de cada foliolo não estão se } \\
\text { tocando. }\end{array}$ \\
\hline$V_{n}$ & "Enésimo" nó maduro & $\begin{array}{l}\text { A "enésima" folha trifoliolada está estendida, isto é, } \\
\text { com os três folíolos expandidos e a folha trifoliolada } \\
\text { " } n+1 \text { " está suficientemente aberta, de tal modo que } \\
\text { os bordos de cada foliolo não estão se tocando. }\end{array}$ \\
\hline
\end{tabular}

Fonte: Fehr \& Caviness (1977), adaptada por Câmara (1998b). 
Tabela 7. Descrição dos estádios reprodutivos da soja.

\begin{tabular}{|c|c|c|}
\hline Símbolo & Denominação & Descrição \\
\hline$R_{1}$ & Início do florescimento & Uma flor aberta em qualquer nó da haste principal. \\
\hline $\mathrm{R}_{2}$ & Florescimento pleno & $\begin{array}{l}\text { Uma flor aberta em um dos dois últimos nós da } \\
\text { haste principal, com a folha completamente } \\
\text { desenvolvida. }\end{array}$ \\
\hline$R_{3}$ & Início da frutificação & $\begin{array}{l}\text { Vagem com } 5 \mathrm{~mm} \text { de comprimento em um dos } \\
\text { quatro últimos nós superiores, sobre a haste } \\
\text { principal, com a folha completamente } \\
\text { desenvolvida. }\end{array}$ \\
\hline $\mathbf{R}_{\mathbf{4}}$ & Vagem formada & $\begin{array}{l}\text { Vagem com } 20 \mathrm{~mm} \text { de comprimento em um dos } \\
\text { quatro últimos nós superiores, sobre a haste } \\
\text { principal, com a folha completamente desenvolvida } \\
\text { ("canivete"). }\end{array}$ \\
\hline$R_{5}$ & $\begin{array}{l}\text { Início da formação da } \\
\text { semente ou inicio da } \\
\text { granação }\end{array}$ & $\begin{array}{l}\text { Semente com } 3 \mathrm{~mm} \text { de comprimento em uma } \\
\text { vagem localizada em um dos quatro últimos nós } \\
\text { superiores, sobre a haste principal, com a folha } \\
\text { completamente desenvolvida. }\end{array}$ \\
\hline $\mathrm{R}_{6}$ & $\begin{array}{l}\text { Granação plena ou } \\
\text { semente desenvolvida }\end{array}$ & $\begin{array}{l}\text { Vagem verde, contendo semente verde que } \\
\text { preenche a cavidade da vagem localizada em um } \\
\text { dos quatro últimos nós superiores, sobre a haste } \\
\text { principal, com a folha completamente } \\
\text { desenvolvida. }\end{array}$ \\
\hline $\mathrm{R}_{7}$ & $\begin{array}{l}\text { Início da maturação ou } \\
\text { maturação fisiológica }\end{array}$ & $\begin{array}{l}\text { Uma vagem normal sobre a haste principal que } \\
\text { tenha atingido a cor da vagem madura. }\end{array}$ \\
\hline$R_{8}$ & $\begin{array}{l}\text { Maturação plena ou } \\
\text { maturação a campo }\end{array}$ & $\begin{array}{l}95 \% \text { de vagens que tenham atingido a cor da } \\
\text { vagem madura. }\end{array}$ \\
\hline
\end{tabular}

Fonte: Fehr \& Caviness (1977), adaptada por Câmara (1998b).

\subsection{Características avaliadas}

Para verificar os prováveis efeitos dos fatores épocas de semeadura, cultivares e densidades sobre as características agronômicas das plantas, providenciou-se a coleta de 10 plantas de soja aleatórias por parcela, que se encontravam no estádio $R_{8}$, nas quais foram avaliadas as seguintes características: altura final de planta; altura de inserção da primeira vagem; número nós; número de ramificações; diâmetro da haste principal; número de 
vagens chochas; número diferenciado de grãos por vagem; número total de vagens e número total de grãos.

Determinou-se também, nesse mesmo estádio fenológico, o acamamento na área útil de cada parcela. Após a colheita das parcelas, foram determinados a massa de 1000 grãos e o rendimento.

\subsubsection{Altura final de planta}

Considerou-se como altura final de planta, a distância compreendida entre a superfície do solo e a extremidade apical (tufo foliar) da haste principal da planta.

\subsubsection{Altura de inserção da primeira vagem}

A altura de inserção da primeira vagem foi determinada medindo-se a distância compreendida entre a superfície do solo e o ponto de inserção da primeira vagem na haste principal da planta.

\subsubsection{Número de nós}

Esta característica foi obtida pela contagem do número de nós formados na haste principal da planta, iniciando-se no nó de inserção das folhas unifolioladas até o último nó na extremidade apical da haste, correspondente à inserção da última folha trifoliolada.

\subsubsection{Número de ramificaçōes}

O número de ramificações por planta foi obtido pela contagem direta do número de ramos inseridos na haste principal da planta. 


\subsubsection{Diâmetro da haste principal}

Determinou-se o diâmetro da haste principal através de leitura com paquímetro, medindo-se a região compreendida entre o colo da planta e a cicatriz do nó cotiledonar.

\subsubsection{Número de vagens chochas e número de grãos por vagem}

Obteve-se por meio de contagem direta o número total de vagens chochas e de vagens com um, dois, três ou mais grãos formados em cada planta.

\subsubsection{Número total de vagens}

O número total de vagens foi obtido através da contagem direta do total das vagens formadas em cada planta.

\subsubsection{Número total de grãos}

Determinou-se o número total de grãos através da contagem direta do número de grãos formados em cada planta.

\subsubsection{Acamamento}

Foi determinado por notas atribuidas em escala variável de 1 a 5 , onde 1 e 5 representaram respectivamente, o maior e o menor grau de resistência ao acamamento, conforme Marcos Filho \& Novembre (1990). Desta forma, adotaram-se os seguintes valores percentuais para a visualização de plantas 
acamadas: 1 (até $10 \%) ; 2(11 \%$ a $25 \%) ; 3(26 \%$ a $50 \%) ; 4(51 \%$ a $80 \%)$ e 5 (acima de $80 \%$ ).

Após estas determinações realizadas antes da colheita, procedeu-se a colheita manual das plantas da área útil de cada parcela e posteriormente a trilha em máquina estacionária. Os grãos limpos e acondicionados em sacos de papel foram encaminhados ao Laboratório de Análise de Sementes do Departamento de Agricultura da ESALQ/USP e após sete dias de armazenamento em ambiente natural, determinou-se a massa de 1000 grãos e o rendimento.

\subsubsection{Massa de 1000 grãos}

Para determinação da massa de 1000 grãos foram separadas 8 subamostras de 100 grãos por parcela, cujas massas foram determinadas em balança com sensibilidade de centésimos de grama, sendo tais procedimentos efetuados segundo prescrições estabelecidas pelas Regras de Análise de Sementes (Brasi - Ministério da Agricultura, 1992), devido a não existência de metodologia própria para determinação da massa de 1000 grãos.

Após a obtenção dessa massa e baseando-se na umidade desses grãos, calculou-se a massa de 1000 grãos corrigida para a umidade de $13 \%$, de acordo com a expressão (1) apresentada a seguir.

$$
\begin{aligned}
& \text { Mc }=\text { Mo }\left[1-(\text { Uo\%/100) }] /\left[1-\left(U_{c} \% / 100\right)\right]\right. \\
& \text { onde, } \\
& \begin{aligned}
M c & =\text { Massa corrigida; } \\
M o & =\text { Massa obtida; } \\
\text { Uo } & =\text { Grau de umidade observado; } \\
\text { Uc } & =\text { Grau de umidade de correção. }
\end{aligned}
\end{aligned}
$$




\subsubsection{Rendimento}

O rendimento foi obtido através da pesagem dos grãos de cada parcela experimental e o valor em kg.parcela ${ }^{-1}$ foi transformado em kg.ha ${ }^{-1}$, sendo também, corrigido a umidade a $13 \%$, através da expressão (1).

\subsection{Clima e desenvolvimento das plantas}

Por meio de estação meteorológica automática instalada próxima a área experimental, coletaram-se dados diários de temperatura média do ar e precipitação pluvial, cujos respectivos valores médios e totais mensais plotados graficamente ao longo do período de experimentação são apresentadas na Figura 1.

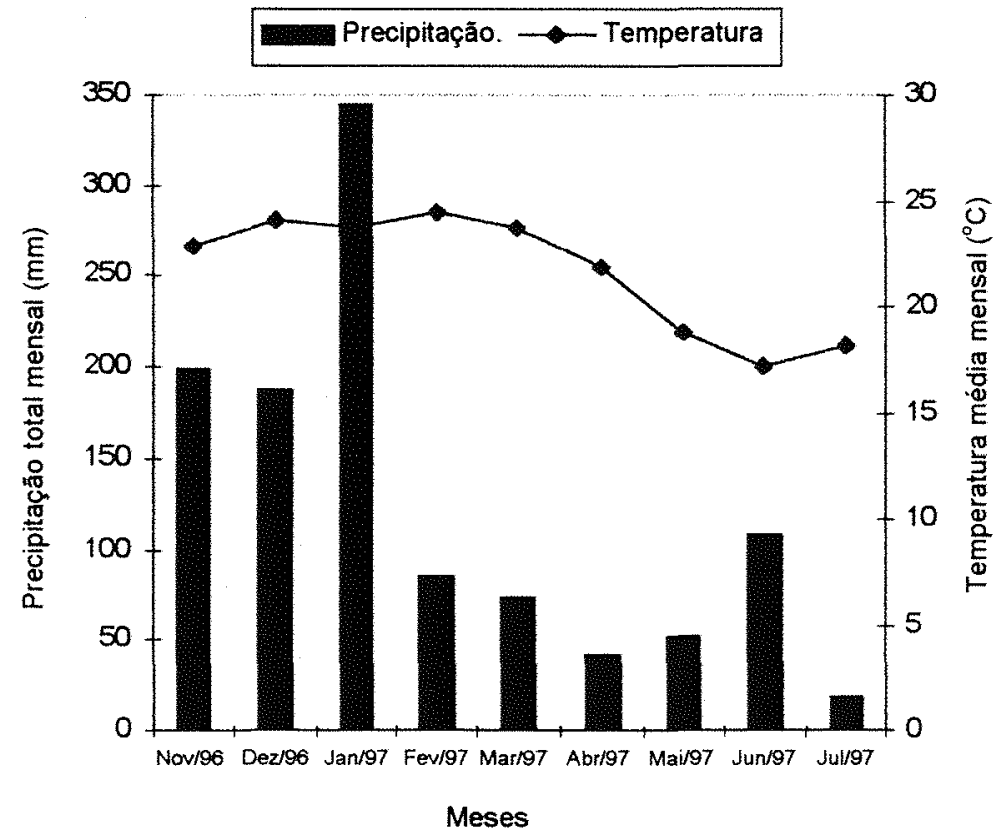

Figura 1. Precipitação total mensal e temperatura média mensal nas épocas de semeadura normal e tardia. 
Nota-se que $\circ$ ambiente climático foi plenamente favorável ao crescimento e desenvolvimento das plantas de soja semeadas nas épocas normal e tardia. Nota-se também, que a relativa queda de temperatura associada à redução da precipitação a partir de março de 1997 favoreceram a maturação final das plantas. Desta forma, pode-se considerar que não ocorreram interferências negativas destes elementos de clima sobre os fatos e resultados observados neste trabalho. 


\section{RESULTADOS E DISCUSSÃO}

Os valores dos quadrados médios residuais e respectivas significâncias estatísticas relativas às variáveis analisadas são apresentados nos Apêndices 1,2 e 3.

Para a época de semeadura normal a análise da variância revelou valores de $F$ altamente significativos para o fator cultivar, relativos às variáveis altura final de planta, altura de inserção da primeira vagem, número de nós e número de ramificações na haste principal, número de vagens chochas, número de vagens com três grãos, número total de grãos, massa de 1000 grãos e rendimento. Valores de $F$ significativos $(P<0,05)$ para o fator cultivar foram detectados apenas para a variável diâmetro da haste principal (Apêndice 1).

Para o fator densidade na primeira época de semeadura, o teste $F$ da análise da variância revelou valores significativos $(P<0,01)$ para as variáveis altura final de planta, diâmetro da haste principal, número de vagens chochas, número de vagens com dois grãos, número de vagens com três grãos, número total de vagens e número total de grãos; significância a 0,05 foi detectada somente para a variável número de ramificações. Para as demais variáveis não foram constatados valores significativos relativos ao fator densidade (Apêndice 1).

Com relação à interação dos fatores cultivar e densidade, o teste $F$ da análise da variância revelou valores altamente significativos para as variáveis altura de inserção da primeira vagem, número de vagens chochas, número de vagens com dois grãos, número total de vagens e número total de grãos; significância a 0,05 foi detectada para as variáveis diâmetro da haste principal e 
número de vagens com três grãos. Para as demais variáveis não foram detectadas significâncias estatísticas relativas à interação desses fatores (Apêndice 1).

Para a época de semeadura tardia a análise da variância revelou valores de $F$ altamente significativos para o fator cultivar, relativos às variáveis altura final de planta, número de vagens chochas, número de vagens com três grãos, número total de grãos e massa de 1000 grãos, enquanto que valor significativo $(\mathrm{P}<0,05)$ foi detectado apenas para a variável número de vagens com dois grãos. Para as demais características, $O$ teste $F$ não revelou diferenças significativas (Apêndice 2).

Para o fator densidade na época de semeadura tardia, o teste $F$ da análise da variância revelou valores altamente significativos para as variáveis altura final de planta, número de ramificações, diâmetro da haste principal, número de vagens com dois grãos, número de vagens com três grãos, número total de vagens e número total de grãos. Para as demais variáveis não houve diferenças significativas. Para a interação dos fatores cultivar e densidade o teste $F$ não revelou diferenças estatísticas para nenhuma das variáveis analisadas (Apêndice 2).

A análise conjunta das épocas normal e tardia objetivou a detecção do efeito do fator época sobre as variáveis estudadas. A análise da variância revelou valores de $F$ altamente significativos para a interação tripla dos fatores época, cultivar e densidade, relativos às variáveis altura final de planta, número de nós, número de vagens chochas e massa de 1000 grãos; significância a 0,05 para a variável número de ramificações. Para as demais características o teste $F$ não revelou valores significativos relativos a interação tripla dos fatores (Apêndice 3). 


\subsection{Acompanhamento fenológico}

A duração dos diversos estádios fenológicos dos cultivares de soja IAC17, IAC-12 e IAC-19 pode ser observada na Tabela 8 . Nota-se que os três cultivares quando semeados em época normal, tiveram desempenho semelhante até o estádio $R_{5}$, a partir do qual começaram a ocorrer diferenças como as observadas para o cultivar IAC-19. As diferenças na duração do ciclo de maturação ocorreram efetivamente no subperíodo $R_{7}-R_{8}$. Neste caso, os cultivares $\mathrm{IAC}-17$ e $\mathrm{IAC}-12$ apresentaram praticamente o mesmo ciclo de maturação, apesar de serem considerados precoce e semi precoce, respectivamente.

Tabela 8. Duração média (dias) das principais fases de desenvolvimento dos cultivares de soja IAC-17, IAC-12 e IAC-19 observada nas épocas de semeadura normal e tardia.

\begin{tabular}{|c|c|c|c|c|c|c|c|c|}
\hline Épocas & Cultivares & S-VE & DAE-R1 & DAE-R3 & DAE-R5 & DAE-R7 & DAE-R8 & S-R8 \\
\hline & IAC-17 & 8 & 46 & 62 & 79 & 110 & 125 & 133 \\
\hline \multirow[t]{3}{*}{ Normal } & $\mid A C-12$ & 8 & 46 & 62 & 79 & 110 & 126 & 134 \\
\hline & $\mid A C-19$ & 8 & 46 & 62 & 79 & 114 & 138 & 146 \\
\hline & $\mid A C-17$ & 8 & 39 & 50 & 60 & 82 & 92 & 100 \\
\hline \multirow[t]{2}{*}{ Tardia } & $\mid A C-12$ & 8 & 39 & 53 & 63 & 88 & 103 & 111 \\
\hline & IAC-19 & 8 & 39 & 57 & 68 & 103 & 121 & 129 \\
\hline
\end{tabular}

Obs.: $\mathrm{S}$ = semeadura; DAE = dias após a emergência das plântulas.

$\mathrm{Na}$ época tardia, diferenças entre a duração dos ciclos de maturação dos cultivares foram observadas a partir do subperíodo $R_{1}-R_{3}$.

Ao se comparar as duas épocas de semeadura, observou-se que os cultivares reduziram o ciclo de maturação, quando semeados em época tardia, confirmando o efeito do fotoperíodo na redução do ciclo de maturação dos cultivares, quando semeados fora da época de semeadura recomendada. Estes resultados estão de acordo com Yuyama (1979), Melhorança \& Mesquita (1982), Klar et al. (1986), Bhéring (1989). O encurtamento no período relativo 
ao início da floração $\left(R_{1}\right)$ até a maturidade fisiológica $\left(R_{7}\right)$, foi maior no cultivar IAC-17, o qual apresenta ciclo de maturação precoce. Como também observado por Marchiori (1998), em cada época de semeadura, a fase do ciclo que sofreu alteração, em função da época de semeadura, foi a compreendida entre o início da floração e a maturidade fisiológica, com as plantas mantendo suas características de juvenilidade próprias a cada cultivar.

\subsection{Altura final de planta}

O teste de Tukey para comparação de médias revelou diferenças significativas para altura final de planta entre os cultivares nas duas épocas de semeadura (Tabela 9). Na época de semeadura normal, as plantas do cultivar IAC-19 atingiram maior altura final diferindo significativamente dos cultivares $\mid A C-17$ e $\mid A C-12$, os quais não diferiram entre si. Porém, na época de semeadura tardia, os cultivares IAC-17 e IAC-19 foram estatisticamente iguais, atingindo maior altura de planta que o cultivar IAC-12.

Tabela 9. Valores médios para altura final de planta de soja $(\mathrm{cm})$, observados nos cultivares IAC-17, IAC-12 e IAC-19, em cinco densidades de plantas, nas épocas de semeadura normal e tardia.

\begin{tabular}{|c|c|c|c|c|c|c|c|}
\hline \multirow{2}{*}{ Épocas } & \multirow{2}{*}{ Cultivares } & \multicolumn{5}{|c|}{ Densidades (plantas. $m^{-1}$ ) } & \multirow{2}{*}{ Médias } \\
\hline & & 10 & 15 & 20 & 25 & 30 & \\
\hline & IAC - 17 & 70,0 & 71,3 & 80,8 & 80,6 & 76,5 & $75,8^{1} \mathrm{~b}$ \\
\hline \multirow[t]{4}{*}{ Normal } & IAC - 12 & 70,6 & 74,1 & 83,5 & 82,5 & 85,2 & 79,2 b \\
\hline & $\mid A C-19$ & 81,2 & 92,8 & 91,8 & 90,6 & 94,6 & $90,2 \mathrm{a}$ \\
\hline & \multicolumn{4}{|c|}{ D.M.S. $\quad 3,98$} & C.V. (\%) & 5,39 & \\
\hline & IAC - 17 & 63,0 & 63,8 & 66,2 & 68,2 & 69,0 & $66,1^{1} a$ \\
\hline \multirow[t]{2}{*}{ Tardia } & IAC - 12 & 52,6 & 48,5 & 58,3 & 66,6 & 62,1 & 57,6 b \\
\hline & IAC - 19 & 60,5 & 65,6 & 62,9 & 76,1 & 72,9 & $67,6 a$ \\
\hline
\end{tabular}

D.M.S. 4,76

C.V. (\%) 8,25

Médias seguidas por letras distintas na coluna diferem entre si pelo teste de Tukey a 0,05 de significância. 
Alterando-se a densidade de semeadura, altera-se a densidade de plantas na linha, de maneira que, por meio do manejo populacional modifica-se a altura da planta. Neste trabalho, o teste $\mathrm{F}$ da análise de regressão polinomial, revelou valores altamente significativos para regressão quadrática na primeira época de semeadura e linear na segunda época (Anexo A). Desse modo, verificou-se que na época de semeadura normal, quando se aumentou a densidade de plantas de 10 até aproximadamente 26 plantas. $\mathrm{m}^{-1}$, ocorreu aumento na altura final de planta, sendo que após esse valor, ocorreram decréscimos (Figura 2). Entretanto, na época de semeadura tardia, a altura de planta aumentou linearmente com o aumento da densidade de 10 para 30 plantas. $\mathrm{m}^{-1}$, sendo que cada planta de soja semeada a mais na linha, provocou um acréscimo de $0,59 \mathrm{~cm}$ na altura final, conforme pode ser visto na Figura 2.

Além disso, o cultivar IAC-12 quando semeado em época tardia nas densidades de 10,15 e 20 plantas. $\mathrm{m}^{-1}$ não atingiu a altura mínima de planta de soja, preconizada por vários autores como ideal para a colheita mecanizada da cultura, ou seja, $60 \mathrm{~cm}$ (Gilioli et al., 1979; Sediyama et al., 1985). Nessa situação, pode-se manejar a população de plantas do cultivar IAC-12 para que se obtenham plantas com altura superior a esse valor, o que pode ser conseguido com o aumento da densidade de plantas, trabalhando-se com 25 ou 30 plantas. $\mathrm{m}^{-1}$.

$\mathrm{Na}$ análise conjunta das épocas de semeadura, os resultados mostraram que a altura de planta foi influenciada significativamente pela interação tripla entre época, cultivar e densidade. As variações observadas nesta característica entre as épocas de semeadura normal e tardia para os três cultivares e nas cinco densidades, são apresentadas na Tabela 10.

Quando se compara a altura final de planta entre as épocas de semeadura normal e tardia, observa-se diminuição nesta característica na segunda época em relação a época considerada normal, para os três cultivares estudados. Estes resultados estão de acordo com os observados por outros 
pesquisadores (Yuyama, 1979; Marcos Filho \& Novembre, 1990; Câmara, 1991; Marchiori, 1998).

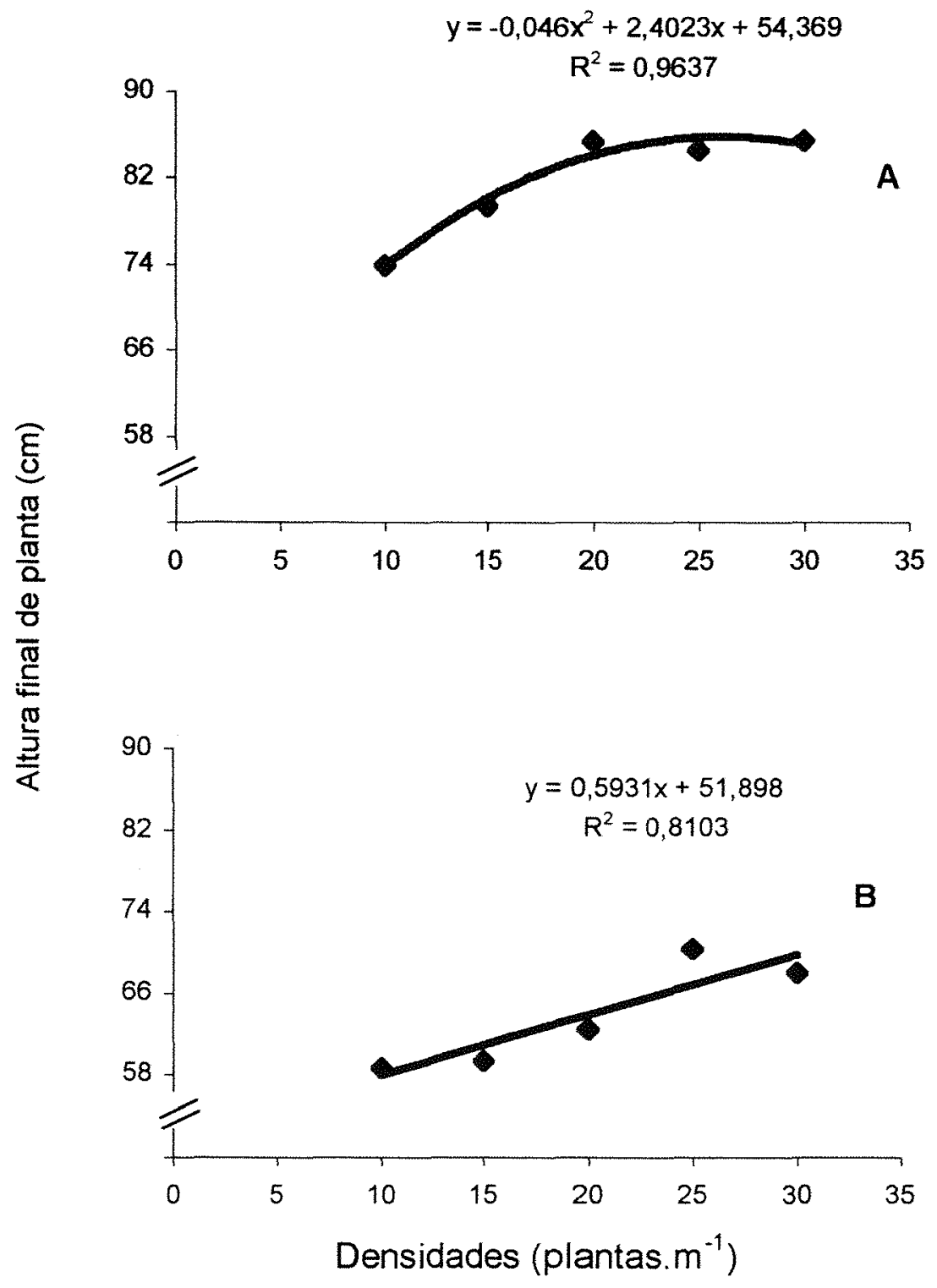

Figura 2. Variação na altura final de planta de soja em função da densidade de plantas na linha de semeadura nas épocas de semeadura normal (A) e tardia (B). 
Para o cultivar IAC-17, na época de semeadura normal a altura de planta foi significativamente maior que na época de semeadura tardia nas densidades de 20 e 25 plantas. $m^{-1}$, enquanto que nas demais densidades não houve diferenças estatísticas. Porém, os cultivares IAC-12 e IAC-19, apresentaram valores significativamente maiores de altura de planta na época de semeadura normal, em todas as densidades estudadas. Houve decréscimos na altura de planta dos três cultivares de soja da época de semeadura normal para a tardia (Tabela 10), sendo mais acentuados nos cultivares IAC-12 e IAC-19, onde a diferença média foi de 21,5 e $22,6 \mathrm{~cm}$, respectivamente. Isso se deve, provavelmente, ao encurtamento no ciclo de maturação destes cultivares, quando semeados tardiamente. O cultivar IAC-17 foi o que apresentou menor decréscimo de altura com o atraso da semeadura, provavelmente, devido a presença do caráter juvenilidade longa neste cultivar.

Tabela 10. Valores médios de altura de planta $(\mathrm{cm})$ dos cultivares (Cvs.) de soja IAC-17, IAC-12 e IAC-19, em cinco densidades de plantas, observados nas épocas de semeadura normal e tardia.

\begin{tabular}{|c|c|c|c|c|c|c|c|c|}
\hline \multirow{2}{*}{ Cvs. } & \multirow{2}{*}{$E^{1}$} & \multicolumn{6}{|c|}{ Densidades (plantas. $\mathrm{m}^{-1}$ ) } & \multirow{2}{*}{ Médias } \\
\hline & & 10 & & 15 & 20 & 25 & 30 & \\
\hline \multirow{2}{*}{ IAC - 17} & $N$ & $70,0^{2}$ & $a$ & 71,3 a & 80,8 a & 80,6 a & 76,5 a & 75,8 \\
\hline & $T$ & 63,0 & a & 63,8 a & $66,2 \quad b$ & $68,2 \quad b$ & 69,0 a & 66,1 \\
\hline \multirow{2}{*}{ IAC - 12} & $N$ & 70,6 & a & 74,1 a & 83,5 a & 82,5 a & $85,2 a$ & 79,2 \\
\hline & $T$ & 52,6 & $b$ & $48,5 \quad b$ & $58,3 \quad b$ & $66,6 \quad b$ & $62,1 \quad \mathrm{~b}$ & 57,6 \\
\hline \multirow{3}{*}{$I A C-19$} & $N$ & 81,2 & a & 92,8 a & 91,8 a & 90,6 a & 94,6 a & 90,2 \\
\hline & $T$ & 60,5 & $b$ & $65,6 \quad b$ & $62,9 \quad b$ & $76,1 \quad b$ & $72,9 \quad b$ & 67,6 \\
\hline & & & D.I & 1.S. 7,95 & & 1. (\%) $\quad 6,67$ & & \\
\hline
\end{tabular}

Épocas de semeadura: $\mathrm{N}=$ normal $\mathrm{e} T=$ tardia.

${ }^{2}$ Médias seguidas por letras distintas na coluna diferem entre si pelo teste de Tukey a 0,05 de significância. 


\subsection{Altura de inserção da primeira vagem}

Na Tabela 11 são apresentados os valores médios da altura de inserção da primeira vagem determinados nos cultivares IAC-17, IAC-12 e IAC-19, em cinco densidades de plantas nas duas épocas de semeadura.

Tabela 11. Valores médios da altura de inserção da primeira vagem $(\mathrm{cm})$, observados nos cultivares IAC-17, IAC-12 e IAC-19, em cinco densidades de plantas, nas épocas de semeadura normal e tardia.

\begin{tabular}{|c|c|c|c|c|c|c|c|}
\hline \multirow{2}{*}{ Épocas } & \multirow{2}{*}{ Cultivares } & \multicolumn{5}{|c|}{ Densidades (plantas. $m^{-1}$ ) } & \multirow{2}{*}{ Médias } \\
\hline & & 10 & 15 & 20 & 25 & 30 & \\
\hline & $\mid A C-17$ & $18,2^{1} a$ & $21,4 a$ & $20,5 a$ & $20,3 a$ & $19,1 \quad b$ & 19,9 \\
\hline \multirow[t]{4}{*}{ Normal } & $\mid A C-12$ & $14,1 \quad b$ & $16,8 \quad b$ & 19,9 a & $19,2 \mathrm{a}$ & 23,2 a & 18,6 \\
\hline & $\mid A C-19$ & $15,6 a b$ & $15,5 \quad b$ & $10,6 \quad b$ & $13,0 \quad b$ & 12,7 & 13,5 \\
\hline & & D.N & S. 4,00 & & V. (\%) 1 & 40 & \\
\hline & $\mid A C-17$ & 17,3 & 19,7 & 21,4 & 21,4 & 20,2 & $20,0 \mathrm{a}$ \\
\hline \multirow[t]{3}{*}{ Tardia } & $\mid A C-12$ & 14,2 & 16,7 & 20,6 & 23,7 & 25,1 & $20,1 \mathrm{a}$ \\
\hline & $\mid A C-19$ & 17,6 & 18,6 & 19,3 & 24,6 & 20,2 & $20,1 a$ \\
\hline & & D.N & S. 3,32 & & V. (\%) & & \\
\hline
\end{tabular}

Médias seguidas por letras distintas na coluna diferem entre si pelo teste de Tukey a 0,05 de significância.

Nota-se na Tabela 11, que os cultivares IAC-17, IAC-12 e IAC-19, quando semeados em época normal, apresentaram diferenças estatísticas para a altura de inserção da primeira vagem em todas as densidades estudadas. $\mathrm{Na}$ densidade de 10 plantas $\mathrm{m}^{-1}$, o maior valor para altura de inserção da primeira vagem foi observado nas plantas do cultivar $\mid A C-17$ e o menor no cultivar IAC-12, sendo que o cultivar IAC-19 não diferiu de ambos. Na densidade de 15 plantas $\mathrm{m}^{-1}$, o maior valor para esta caracteristica avaliada, foi observado nas plantas do cultivar IAC-17 e os menores, nos cultivares IAC-12 e IAC-19, que não diferiram entre si. Nas densidades de 20 e 25 plantas. $\mathrm{m}^{-1}$, a altura de inserção da primeira vagem do cultivar IAC-17 foi estatisticamente igual a do 
IAC-12, sendo estas, superiores a alcançada pelo IAC-19. Contudo, na densidade de 30 plantas. $\mathrm{m}^{-1}$ os três cultivares diferiram estatisticamente, sendo que o IAC-12 apresentou maior altura de inserção da primeira vagem e o IAC19 a menor, sendo que o IAC-17, apresentou valor intermediário entre esses dois cultivares.

Embora os fatos acima citados tenham ocorrido na época de semeadura normal, os mesmos não foram observados na época tardia, onde os cultivares, independente da densidade de plantas utilizada, apresentaram a mesma altura de inserção da primeira vagem (Tabela 11).

Para verificar o efeito da densidade de plantas na altura de inserção da primeira vagem de cada cultivar, analisaram-se os dados através da regressão polinomial, a qual detectou valores de $F$ altamente significativos dentro do cultivar IAC-12 na primeira época de semeadura. As médias da altura de inserção da primeira vagem desse cultivar, foram ajustadas por equação linear (Anexo A), o que significa dizer que, com o aumento da densidade de 10 para 30 plantas $\mathrm{m}^{-1}$, aumentou a altura de inserção da primeira vagem de $0,41 \mathrm{~cm}$ para cada planta semeada a mais. A mesma tendência foi verificada na segunda época de semeadura, porém, independente do cultivar (Anexo A). O aumento da altura da inserção da primeira vagem com o aumento da densidade de plantas também foi observado por Lam-Sanchez \& Veloso (1974a), Nakagawa et al. (1986b) e Nakagawa et al. (1987). Entretanto, Rosolem et al. (1983) não observaram diferenças significativas em função da densidade e nem das épocas de semeadura nessa característica da planta.

A análise estatística conjunta das épocas de semeadura mostrou haver interação entre época e cultivar e época e densidade, sendo os valores de $F$ significativos a $1 \%$ e a $5 \%$, respectivamente.

$\mathrm{Na}$ Tabela 12, pode-se observar a influência da época de semeadura sobre os cultivares de soja IAC-17, IAC-12 e IAC-19. Nota-se nesta tabela, que independente da densidade de planta utilizada, diferenças significativas foram 
detectadas apenas no cultivar IAC-19, o qual apresentou maior altura de inserção da primeira vagem na segunda época.

Tabela 12. Valores médios da altura de inserção da primeira vagem $(\mathrm{cm})$ dos cultivares (Cvs.) de soja IAC-17, IAC-12 e IAC-19, em cinco densidades de plantas, observados nas épocas de semeadura normal e tardia.

\begin{tabular}{cccccccc}
\hline \multirow{2}{*}{ Cvs. } & \multirow{7}{*}{$\mathrm{E}^{1}$} & \multicolumn{7}{c}{ Densidades (plantas. $\mathrm{m}^{-1}$ ) } & \multirow{2}{*}{ Médias } \\
\cline { 3 - 7 } & & 10 & 15 & 20 & 25 & 30 & \\
\hline \multirow{2}{*}{ IAC - 17} & $\mathrm{~N}$ & 18,2 & 21,4 & 20,5 & 20,3 & 19,1 & $19,9^{2} \mathrm{a}$ \\
& $\mathrm{T}$ & 17,3 & 19,7 & 21,4 & 21,4 & 20,2 & $20,0 \quad \mathrm{a}$ \\
\hline \multirow{2}{*}{ IAC - 12 } & $\mathrm{N}$ & 14,1 & 16,8 & 19,9 & 19,2 & 23,2 & $18,6 \mathrm{a}$ \\
& $\mathrm{T}$ & 14,2 & 16,7 & 20,6 & 23,7 & 25,1 & $20,1 \mathrm{a}$ \\
\hline \multirow{2}{*}{ IAC - 19 } & $\mathrm{N}$ & 15,6 & 15,5 & 10,6 & 13,0 & 12,7 & $13,5 \quad \mathrm{~b}$ \\
& $\mathrm{~T}$ & 17,6 & 18,6 & 19,3 & 24,6 & 20,2 & $20,1 \mathrm{a}$ \\
\hline
\end{tabular}

$\begin{array}{ll}\text { D.M.S. } 2,16 & \text { C.V. (\%) } 15,75\end{array}$

Epocas de semeadura: $N=$ normal e $T=$ tardia.

${ }^{2}$ Médias seguidas por letras distintas na coluna diferem entre si pelo teste de Tukey a 0,05 de significância.

Embora o aumento na altura de inserção da primeira vagem observada no cultivar IAC-19 (Tabela 12) seja concordante com os resultados verificados nos cultivares estudados por Yuyama (1979), os mesmos são discordantes dos encontrados por Marcos Filho \& Novembre (1990).

\subsection{Número de nós}

Os valores médios do número de nós formados na haste principal das plantas de soja dos cultivares IAC-17, IAC-12 e IAC-19, em cinco densidades de plantas, observados nas épocas de semeadura normal e tardia, são apresentados na Tabela 13.

$\mathrm{Na}$ época de semeadura normal, o cultivar IAC-19 apresentou estatisticamente maior quantidade de nós na haste principal das plantas quando 
comparado com os demais cultivares e entre estes, o cultivar IAC-12 superou o IAC-17. Este fato pode ser relacionado com a altura final de planta, pois o cultivar IAC-19 cresceu mais em altura que os demais pelo fato de possuir maior ciclo de maturação, e consequentemente, formar maior quantidade de nós vegetativos na haste principal (Tabelas 8,9 e 13).

Tabela 13. Valores médios do número de nós formados na haste principal de plantas de soja dos cultivares IAC-17, IAC-12 e IAC-19, em cinco densidades de plantas, observados em épocas de semeadura normal e tardia.

\begin{tabular}{|c|c|c|c|c|c|c|c|}
\hline \multirow{2}{*}{ Épocas } & \multirow{2}{*}{ Cultivares } & \multicolumn{5}{|c|}{ Densidades (plantas. $\mathrm{m}^{-1}$ ) } & \multirow{2}{*}{ Médias } \\
\hline & & 10 & 15 & 20 & 25 & 30 & \\
\hline & $\mid A C-17$ & $12,0^{1}$ & 11,7 & 12,3 & 11,7 & 11,7 & $11,9^{2} \mathrm{c}$ \\
\hline \multirow[t]{4}{*}{ Normal } & IAC - 12 & 12,3 & 12,0 & 12,3 & 12,3 & 13,0 & $12,4 \mathrm{~b}$ \\
\hline & $I A C-19$ & 13,0 & 13,3 & 13,0 & 13,3 & 13,3 & $13,2 \mathrm{a}$ \\
\hline & \multicolumn{4}{|c|}{ D.M.S. $\quad 0,07$} & C.V. $(\%)$ & \multicolumn{2}{|l|}{2,31} \\
\hline & $I A C-17$ & 11,7 & 11,3 & 11,3 & 11,3 & 11,0 & $11,3 \mathrm{a}$ \\
\hline \multirow[t]{3}{*}{ Tardia } & $I A C-12$ & 12,3 & 11,0 & 11,7 & 11,6 & 11,0 & $11,5 \mathrm{a}$ \\
\hline & IAC - 19 & 11,7 & 11,7 & 11,3 & 12,0 & 11,3 & $11,6 a$ \\
\hline & & \multicolumn{3}{|c|}{ D.M.S. $\quad 0,09$} & C.V. (\%) & 3,00 & \\
\hline
\end{tabular}

${ }^{1}$ Dados transformados segundo $\sqrt{x}$.

${ }^{2}$ Médias seguidas por letras distintas na coluna diferem entre si pelo teste de Tukey a 0,05 de significância.

$\mathrm{Na}$ segunda época de semeadura, os cultivares IAC-17 e IAC-19 apresentaram altura de planta e número de nós formados na haste principal estatisticamente iguais (Tabelas 9 e 13), sendo o comprimento médio do entrenó igual a $5,8 \mathrm{~cm}$. Porém, para o cultivar $\mathrm{IAC}-12$, a menor altura de planta observada nessa época (Tabela 9) deveu-se, possivelmente, ao menor comprimento médio de cada entrenó $(5,0 \mathrm{~cm})$.

Estes resultados sugerem que a altura de planta não foi condicionada exclusivamente pelo número de nós formados na haste principal, mas também, 
pelo comprimento dos entrenós, fato também observado por Câmara (1991), Medina (1994) e Marchiori (1998).

O número de nós formados na haste principal das plantas de soja, também foi influenciado significativamente pela interação tripla entre época, cultivar e densidade, como observado na análise conjunta das épocas de semeadura (Apêndice 3). Nesta análise, verificou-se que o cultivar IAC-17 formou o mesmo número de nós independente da época de semeadura e da densidade de plantas, como pode ser verificado na Tabela 14.

Tabela 14. Valores médios do número de nós formados na haste principal dos cultivares (Cvs.) de soja IAC-17, IAC-12 e IAC-19, em cinco densidades de plantas, observados nas épocas de semeadura normal e tardia.

\begin{tabular}{|c|c|c|c|c|c|c|c|}
\hline \multirow{2}{*}{ Cvs. } & \multirow{2}{*}{$E^{1}$} & \multicolumn{5}{|c|}{ Densidades (plantas. $m^{-1}$ ) } & \multirow{2}{*}{ Médias } \\
\hline & & 10 & 15 & 20 & 25 & 30 & \\
\hline \multirow{2}{*}{$\mid A C-17$} & $N$ & $12,0^{2,3} \mathrm{a}$ & 11,7 a & 12,3 a & 11,7 a & $11,7 \mathrm{a}$ & 11,9 \\
\hline & $T$ & $11,7 \quad a$ & 11,3 a & 11,3 a & 11,3 a & $11,0 \mathrm{a}$ & 11,3 \\
\hline \multirow{2}{*}{$I A C-12$} & $N$ & 12,3 a & 12,0 a & 12,3 a & 12,3 a & 13,0 a & 12,4 \\
\hline & $T$ & 12,3 a & $11,0 \mathrm{a}$ & 11,7 a & 11,6 a & $11,0 \quad b$ & 11,5 \\
\hline \multirow{3}{*}{$I A C-19$} & $N$ & 13,0 a & 13,3 a & 13,0 a & 13,3 a & 13,3 a & 13,2 \\
\hline & $T$ & 11,7 & $11,7 \quad b$ & $11,3 \quad b$ & $12,0 \quad b$ & $11,3 \quad b$ & 11,6 \\
\hline & & & ร. 0,15 & & I. (\%) 2,6 & & \\
\hline
\end{tabular}

Epocas de semeadura: $\mathrm{N}=$ nornal $\mathrm{e} T=$ tardia.

${ }^{2}$ Dados transformados segundo $\sqrt{x}$.

${ }^{3}$ Médias seguidas por letras distintas na coluna diferem entre si pelo teste de Tukey a 0,05 de significância.

Da mesma forma, o cultivar IAC-12, não foi influenciado pela época de semeadura na maioria das densidades estudadas, sendo exceção, a densidade de 30 plantas. $\mathrm{m}^{-1}$, na qual foi verificado diferença estatística com superioridade no número de nós formados na primeira época de semeadura. Porém, a época de semeadura influenciou significativamente o número de nós formados na haste principal das plantas de soja do cultivar IAC-19, sendo superior na época 
de semeadura normal em todas as densidades. Este fato observado no cultivar IAC-19, também foi relatado por Tragnago \& Bonetti (1984), os quais verificaram que a diminuição no número de nós formados por planta com o atraso da semeadura, era proporcional à redução no ciclo da cultura.

\subsection{Número de ramificações}

O teste de Tukey aplicado aos valores observados para esta variável na primeira época de semeadura, revelou que o cultivar IAC-17 apresentou maior número de ramificações formadas por planta que os cultivares IAC-12 e IAC-19, estatisticamente iguais entre si. Porém, essa diferença não foi observada na época tardia, onde os três cultivares foram estatisticamente iguais (Tabela 15).

Tabela 15. Valores médios do número de ramificações formadas por planta dos cultivares IAC-17, IAC-12 e IAC-19, em cinco densidades de plantas, observados em épocas de semeadura normal e tardia.

\begin{tabular}{|c|c|c|c|c|c|c|c|}
\hline \multirow{2}{*}{ Épocas } & \multirow{2}{*}{ Cultivares } & \multicolumn{5}{|c|}{ Densidades (plantas. $m^{-1}$ ) } & \multirow{2}{*}{ Médias } \\
\hline & & 10 & 15 & 20 & 25 & 30 & \\
\hline & IAC - 17 & $5,0^{1}$ & 3,7 & 3,3 & 2,3 & 2,8 & $3,4^{2} a$ \\
\hline \multirow[t]{4}{*}{ Normal } & IAC - 12 & 3,0 & 2,0 & 1,0 & 1,6 & 0,4 & $1,5 \mathrm{~b}$ \\
\hline & IAC - 19 & 2,6 & 1,6 & 2,6 & 0,9 & 2,3 & $2,0 \quad b$ \\
\hline & & & 0,38 & & . (\%) & 28,51 & \\
\hline & $\mathrm{IAC}-17$ & $3,7^{1}$ & 3,7 & 2,3 & 3,0 & 2,3 & $3,0^{2} a$ \\
\hline \multirow[t]{3}{*}{ Tardia } & IAC - 12 & 4,0 & 2,9 & 2,6 & 2,0 & 1,3 & $2,5 a$ \\
\hline & IAC - 19 & 3,7 & 2,9 & 3,3 & 2,3 & 1,6 & $2,7 a$ \\
\hline & & & 0,17 & & . $(\%)$ & 11,16 & \\
\hline
\end{tabular}

${ }^{1}$ Dados transformados segundo $\sqrt{x}$.

${ }^{2}$ Médias seguidas por letras distintas na coluna diferem entre si pelo teste de Tukey a 0,05 de significância.

Com relação à densidade de plantas, constatou-se significância para este fator nas duas épocas de semeadura, onde a análise de regressão 
polinomial revelou valores de $F$ altamente significativos com efeito linear, em ambas as épocas, de maneira que, aumentando-se a densidade de plantas de 10 até 30 plantas. $\mathrm{m}^{-1}$, diminuiu-se o número de ramos formados na haste principal, conforme mostram as equações de regressão apresentadas no Anexo A, sendo estes resultados semelhantes aos verificados por Queiroz (1975) e Rosolem et al. (1983). Este fato pode ser explicado, provavelmente, pela competição que ocorre entre as plantas de soja pelos fatores de crescimento do ambiente, especialmente pela luz, ou seja, em maiores densidades de plantas, devido ao número excessivo de plantas na linha, ocorre menor disponibilidade de produtos da fotossíntese para o crescimento vegetativo das plantas na forma de ramificaçōes, sendo estes preferencialmente, destinados ao crescimento em altura da haste principal.

Ainda com relação ao número de ramificações formadas por planta, a análise estatística conjunta revelou valores de $F$ com níveis de significância a 0,05 para a interação tripla entre os fatores época, cultivar e densidade.

Os resultados apresentados na Tabela 16 mostram que a época de semeadura não influenciou na formação do número de ramificações do cultivar IAC-17. Nota-se também, que os cultivares IAC-12 e IAC-19 tiveram desempenho semelhante ao do cultivar IAC-17, com exceção das densidades de 20 plantas. $\mathrm{m}^{-1}$ no cultivar $I A C-12$ e 25 plantas. $m^{-1}$ no cultivar IAC-19, nas quais, o número de ramificações formadas foi significativamente maior na segunda época. Em parte, estes resultados, discordam dos encontrados por Rosolem et al. (1983), os quais verificaram decréscimo no número de ramificações em função das densidades de plantas e das épocas de semeadura.

$\mathrm{Na}$ época de semeadura normal, aproximadamente $78 \%$ da variação no número de ramificações formadas por planta nos cultivares IAC-12 e IAC-17 foi causada pela diferença na densidade de plantas, enquanto que na segunda época, este valor se aproximou de $98 \%$ e $83 \%$ para os cultivares IAC-12 e IAC-19, respectivamente. Estes fatos, observados nas duas épocas de 
semeadura, podem ser explicados pelas equações de regressão apresentadas no Anexo B.

Tabela 16. Valores médios do número de ramificações formadas por planta dos cultivares (Cvs.) de soja IAC-17, IAC-12 e IAC-19, em cinco densidades de plantas, observados em épocas de semeadura normal e tardia.

\begin{tabular}{|c|c|c|c|c|c|c|c|c|}
\hline \multirow{2}{*}{ Cvs. } & \multirow{2}{*}{$E^{1}$} & \multicolumn{6}{|c|}{ Densidades (plantas $\mathrm{m}^{-1}$ ) } & \multirow{2}{*}{ Médias } \\
\hline & & 10 & & 15 & 20 & 25 & 30 & \\
\hline \multirow{2}{*}{ IAC - 17} & $N$ & $5,0^{2,3}$ & & $3,7 \mathrm{a}$ & 3,3 a & $2,3 \mathrm{a}$ & $2,8 a$ & 3,4 \\
\hline & $T$ & 3,7 & $a$ & $3,7 a$ & $2,3 \mathrm{a}$ & 3,0 a & $2,3 a$ & 3,0 \\
\hline \multirow{2}{*}{ IAC - 12} & $\mathrm{~N}$ & 3,0 & $a$ & $2,0 a$ & $1,0 \quad b$ & $1,6 \mathrm{a}$ & $0,4 a$ & 1,5 \\
\hline & $T$ & 4,0 & $a$ & $2,9 \mathrm{a}$ & $2,6 a$ & $2,0 \mathrm{a}$ & $1,3 a$ & 2,5 \\
\hline \multirow{2}{*}{ IAC - 19} & $\mathrm{~N}$ & 2,6 & $a$ & $1,6 a$ & $2,6 a$ & $0,9 \quad b$ & $2,3 a$ & 2,0 \\
\hline & $T$ & 3,7 & $\mathbf{a}$ & $2,9 \mathrm{a}$ & 3,3 a & $2,3 \mathrm{a}$ & $1,6 a$ & 2,7 \\
\hline
\end{tabular}

Epocas de semeadura: $\mathrm{N}=$ normal e $\mathrm{T}=$ tardia.

${ }^{2}$ Dados transformados segundo $\sqrt{x}$.

${ }^{3}$ Médias seguidas por letras distintas na coluna diferem entre si pelo teste de Tukey a 0,05 de significância.

\subsection{Diâmetro da haste principal}

As diferenças estatísticas reveladas pelo teste de Tukey na primeira época de semeadura foram detectadas apenas na densidade de 10 plantas. $\mathrm{m}^{-1}$ (Tabela 17), onde as plantas do cultivar IAC-12 apresentaram maior diâmetro da haste principal e o cultivar IAC-19 o menor, enquanto que o cultivar IAC-17 não diferiu destes.

Ao se examinar os dados referentes a segunda época de semeadura, nota-se que em relação ao diâmetro da haste principal, os três cultivares de soja estudados apresentaram desempenho semelhante, não diferindo estatisticamente entre si. Estes resultados demonstram que a duração do ciclo 
de maturação do cultivar não interferiu no diâmetro da haste principal das plantas de soja, discordando dos resultados encontrados por Yuyama (1979), que verificou associação desta característica com o ciclo vegetativo da cultura, ou seja, quanto menor o período de desenvolvimento, menor o diâmetro da haste principal.

Tabela 17. Valores médios do diâmetro da haste principal $(\mathrm{cm})$, dos cultivares de soja IAC-17, IAC-12 e IAC-19, em cinco densidades de plantas, observados em épocas de semeadura normal e tardia.

\begin{tabular}{|c|c|c|c|c|c|c|c|}
\hline \multirow{2}{*}{ Épocas } & \multirow{2}{*}{ Cultivares } & \multicolumn{5}{|c|}{ Densidades (plantas. $\mathrm{m}^{-1}$ ) } & \multirow{2}{*}{ Médias } \\
\hline & & 10 & 15 & 20 & 25 & 30 & \\
\hline & $I A C-17$ & $0,75^{1} a b$ & $0,62 a$ & $0,64 a$ & $0,52 a$ & $0,55 a$ & 0,61 \\
\hline \multirow[t]{4}{*}{ Normal } & $\mid A C-12$ & $0,87 a$ & $0,66 \mathrm{a}$ & $0,58 a$ & $0,65 a$ & $0,67 a$ & 0,69 \\
\hline & $I A C-19$ & $0,68 \mathrm{~b}$ & $0,67 a$ & $0,69 a$ & $0,55 a$ & $0,61 a$ & 0,64 \\
\hline & & D.M. & S. 0,14 & & V. $(\%)$ & 10,47 & \\
\hline & $\mathrm{IAC}-17$ & $0,66^{1}$ & 0,54 & 0,51 & 0,53 & 0,44 & $0,54 \mathrm{a}$ \\
\hline \multirow[t]{2}{*}{ Tardia } & IAC - 12 & 0,69 & 0,57 & 0,55 & 0,50 & 0,48 & $0,56 \mathrm{a}$ \\
\hline & IAC -19 & 0,63 & 0,56 & 0,53 & 0,52 & 0,42 & $0,53 a$ \\
\hline
\end{tabular}

\footnotetext{
Médias seguidas por letras distintas na coluna diferem entre si pelo teste de Tukey a 0,05 de significância.
}

Com relação à análise de regressão polinomial, verificou-se valores de $F$ altamente significativos para o cultivar IAC-17 e IAC-12 na primeira época de semeadura, enquanto para o IAC-19 encontrou-se 0,05 de significância. Apesar dos valores de $F$ altamente significativos também serem encontrados na segunda época de semeadura, esta não influenciou os cultivares.

$\mathrm{Na}$ época de semeadura normal, os cultivares IAC-17 e IAC-19 apresentaram respostas lineares para as variações nas densidades, porém, para o cultivar IAC-12, a resposta foi quadrática. No caso do cultivar IAC-17, constatou-se que $77 \%$ da variação observada no diâmetro da haste principal foi devido às diferenças nas densidades, sendo expressa pela equação 
apresentada no Anexo $A$, ○ qual contém também a equação para o cultivar IAC-19. Em relação ao cultivar IAC-12, as densidades foram responsáveis por 92\% das variações ocorridas no diâmetro da haste principal das plantas (Anexo A). Além disso, quando se aumenta a densidade de plantas desse cultivar de 10 até aproximadamente 23 plantas. $\mathrm{m}^{-1}$, ocorre decréscimo no diâmetro da haste principal, enquanto que aumentos acima desse valor até 30 plantas $\mathrm{m}^{-1}$ causam aumento no diâmetro da haste principal.

$\mathrm{Na}$ época de semeadura tardia, a análise de regressão polinomial constatou que $91 \%$ das variações observadas no diâmetro da haste principal dos três cultivares foram decorrentes das diferentes densidades, sendo explicadas pela equação observada no Anexo A. Resultados semelhantes foram verificados por Lam-Sanchez \& Veloso (1974a) ao semearam o cultivar Viçoja em época tardia.

A época de semeadura influenciou o diâmetro da haste principal dos cultivares de soja, conforme comprovação da análise estatística conjunta das épocas de semeadura, na qual obteve-se valores de $F$ altamente significativos para o fator época. Na Tabela 18, verifica-se a superioridade da época de semeadura normal sobre a tardia, para esta variável analisada.

Tabela 18. Valores médios do diâmetro da haste principal de plantas de soja (cm) em cinco densidades de plantas, observados nas épocas de semeadura normal e tardia.

\begin{tabular}{cccccccc}
\hline \multirow{2}{*}{ Épocas } & \multicolumn{9}{c}{ Densidades (plantas. $\mathrm{m}^{-1}$ ) } & \multirow{2}{*}{ Médias } \\
\cline { 2 - 6 } & 10 & 15 & 20 & 25 & 30 & & \\
\hline Normal & 0,77 & 0,65 & 0,64 & 0,57 & 0,61 & $0,65^{1}$ & $\mathrm{a}$ \\
Tardia & 0,66 & 0,56 & 0,53 & 0,52 & 0,45 & 0,54 & $\mathrm{~b}$ \\
\hline
\end{tabular}

D.M.S. $0,02 \quad$ C.V. (\%) 9,91

Médias seguidas por letras distintas na coluna diferem entre si pelo teste de Tukey a 0,05 de significância.

A diferença significativa no diâmetro da haste principal de plantas de soja, nas épocas de semeadura normal e tardia (Tabela 18), são semelhantes 
aos resultados encontrados por Yuyama (1979), que verificou redução deste quando se atrasa a semeadura.

\subsection{Número de vagens chochas e número grãos por vagem}

\subsubsection{Número de vagens chochas}

Na Tabela 19 são apresentados os valores médios do número de vagens chochas formadas pelos cultivares de soja IAC-17, IAC-12 e IAC-19, em cinco densidades de plantas, nas épocas de semeadura normal e tardia. Observa-se que na época de semeadura normal, o cultivar IAC-17 produziu maior número de vagens chochas nas densidades de 10 e 15 plantas. ${ }^{-1}$ e não diferiu estatisticamente do cultivar IAC-19 nas densidades de 20 e 25 plantas. $\mathrm{m}^{-1}$, onde ambos apresentaram mais vagens chochas que o cultivar IAC-12. No entanto, na densidade de 30 plantas $\mathrm{m}^{-1}$, maior número de vagens chochas foi observada no cultivar IAC-19 e o menor no IAC-12, sendo que ambos não diferiram do IAC-17.

O cultivar IAC-12 produziu menor número de vagens chochas em todas as densidades estudadas, entretanto, não diferiu estatisticamente do cultivar IAC-19 nas densidades de 10 e 15 plantas. $\mathrm{m}^{-1}$ e do IAC-17 na densidade de 30 plantas. $\mathrm{m}^{-1}$ (Tabela 19).

$\mathrm{Na}$ época de semeadura tardia (Tabela 19), o teste comparativo de médias, revelou diferenças significativas entre os cultivares, independente da densidade de plantas, sendo que o IAC-19 e IAC-12 apresentaram respectivamente, maior e menor número de vagens chochas formadas por planta, enquanto que o IAC-17 não diferiu destes. Em ambas as épocas não se constatou a ocorrência de adversidades climáticas e nem biológicas durante os estádios de frutificação e granação dos genótipos. Desta forma, presume-se 
que o menor chochamento de vagens apresentado pelo cultivar IAC-12 seja um caráter genético do mesmo.

Tabela 19. Valores médios do número de vagens chochas formadas pelos cultivares IAC-17, IAC-12 e IAC-19, em cinco densidades de plantas, observados em épocas de semeadura normal e tardia.

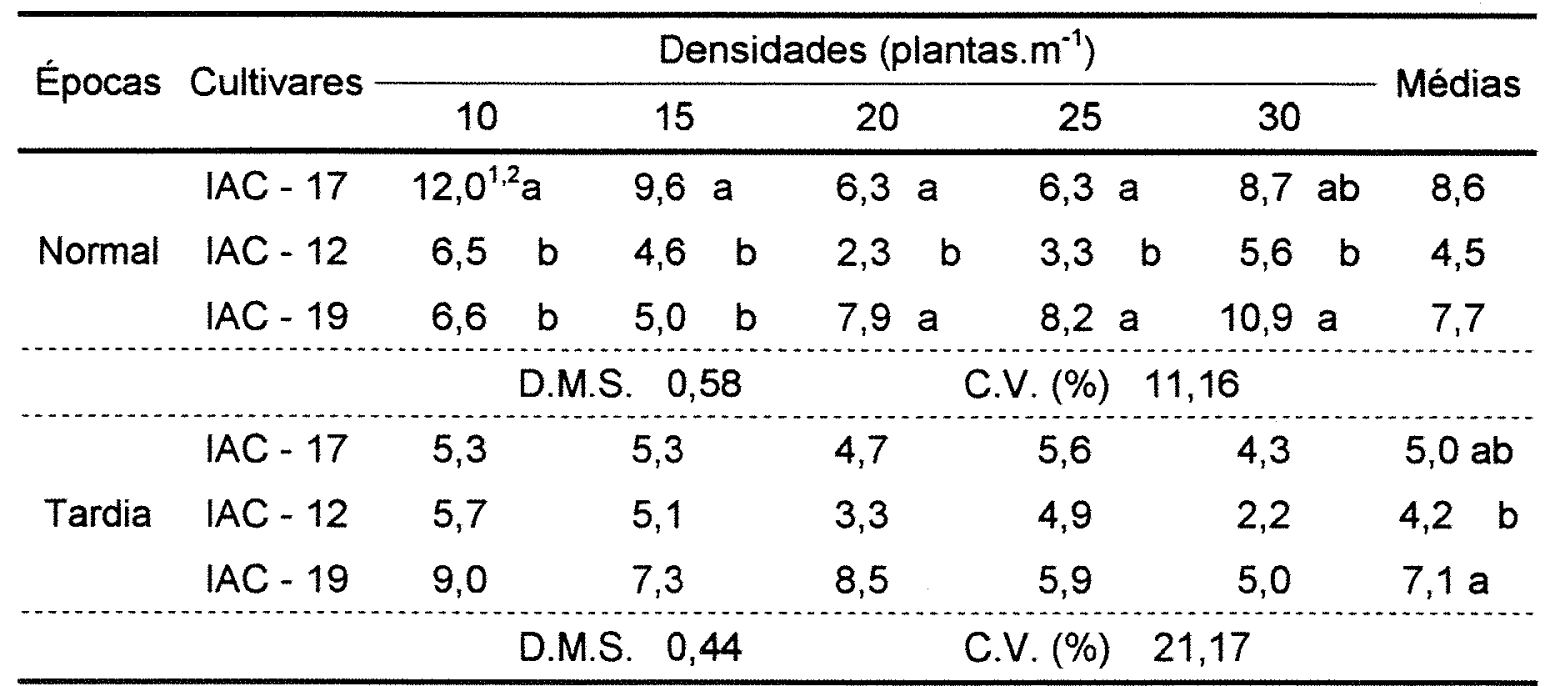

${ }^{1}$ Dados transformados segundo $\sqrt{x}$.

${ }^{2}$ Médias seguidas por letras distintas na coluna diferem entre si pelo teste de Tukey a 0,05 de significância.

Com relação à densidade de plantas, obteve-se valores de $\mathrm{F}$ altamente significativos na primeira época de semeadura, de tal forma que esse efeito foi representado por equações polinomiais quadráticas para os cultivares IAC-17 e IAC-12 e linear para o cultivar IAC-19, conforme se observa no Anexo A.

A análise estatística conjunta das épocas de semeadura para esta variável, permitiu verificar a interação tripla entre os fatores época, cultivar e densidade. Observa-se na Tabela 20, que para todos os cultivares houve efeito de época e densidade. Assim, foram constatadas diferenças significativas para o cultivar IAC-17 nas densidades de 10, 15 e 30 plantas. $\mathrm{m}^{-1}$, nas quais este cultivar produziu maior número de vagens chochas quando semeado em época normal, não ocorrendo diferenças significativas nas demais densidades. Os cultivares IAC-12 e IAC-19 tiveram desempenho semelhante, não apresentando 
diferenças significativas no número de vagens chochas produzidas da época de semeadura normal para tardia na maioria das densidades. Entretanto, pode-se observar na Tabela 20 , diferenças na densidade de 30 plantas. $\mathrm{m}^{-1}$, na qual, esses cultivares produziram maior número de vagens chochas na primeira época de semeadura.

Tabela 20. Valores médios do número de vagens chochas formadas pelos cultivares (Cvs.) de soja IAC-17, IAC-12 E IAC-19, em cinco densidades de plantas, observados nas épocas de semeadura normal e tardia.

\begin{tabular}{|c|c|c|c|c|c|c|c|c|}
\hline \multirow{2}{*}{ Cvs. } & \multirow{2}{*}{$E^{1}$} & \multicolumn{6}{|c|}{ Densidades (plantas $\mathrm{m}^{-1}$ ) } & \multirow{2}{*}{ Médias } \\
\hline & & 10 & & 15 & 20 & 25 & 30 & \\
\hline \multirow{2}{*}{$I A C-17$} & $N$ & $12,0^{2,3}$ & & 9,6 a & $6,3 a$ & $6,3 a$ & 8,7 a & 8,6 \\
\hline & $\mathrm{T}$ & 5,3 & b & $5,3 \quad b$ & $4,7 a$ & 5,6 a & $4,3 \quad b$ & 5,0 \\
\hline \multirow{2}{*}{ IAC - 12} & $N$ & $6,5 a$ & & 4,6 a & $2,3 a$ & $3,3 a$ & 5,6 a & 4,5 \\
\hline & $T$ & 5,7 a & a & 5,1 a & $3,3 \mathrm{a}$ & $4,9 a$ & $2,2 \quad b$ & 4,2 \\
\hline \multirow{2}{*}{$I A C-19$} & $N$ & 6,6 a & & 5,0 a & 7,9 a & $8,2 a$ & 10,9 a & 7,7 \\
\hline & $\mathrm{T}$ & $9,0 a$ & a & 7,3 a & $8,5 \mathrm{a}$ & $5,9 a$ & $5,0 \quad b$ & 7,1 \\
\hline
\end{tabular}

Épocas de semeadura: $\mathrm{N}=$ normal e $\mathrm{T}=$ tardia.

${ }^{2}$ Dados transformados segundo $\sqrt{x}$.

${ }^{3}$ Médias seguidas por letras distintas na coluna diferem entre si pelo teste de Tukey a 0,05 de significância.

O desdobramento da análise de regressão polinomial para a interação tripla entre os fatores época, cultivar e densidade, revelou que as variações no número de vagens chochas formadas na época de semeadura normal pelos cultivares IAC-17 e IAC-12 foram de efeito quadrático e de efeito linear para o IAC-19 (Anexo B). Aumento no número de vagens chochas devido ao aumento na densidade de plantas na linha de semeadura, também foi observado por Rosolem et al. (1983).

$\mathrm{Na}$ época de semeadura tardia, as médias foram ajustadas por equações lineares para os cultivares IAC-12 e IAC-19, através das quais, pode-se verificar 
que com o aumento da densidade de plantas na linha diminuiu o número de vagens chochas formadas por planta. Essas equações podem ser vistas no Anexo B.

\subsubsection{Número de vagens com um grão}

Não houve diferenças estatísticas no número de vagens com um grão produzido pelos cultivares de soja nas duas épocas de semeadura (Tabela 21). Numericamente, os cultivares IAC-17 e IAC-12 quando semeados em época normal e na densidade de 10 plantas. $\mathrm{m}^{-1}$, produziram maior número de vagens com um grão, enquanto que para o cultivar IAC-19, isso foi constatado nas demais densidades.

Tabela 21. Valores médios do número de vagens com um grão formadas pelos cultivares IAC-17, IAC-12 e IAC-19, em cinco densidades de plantas, observados em épocas de semeadura normal e tardia.

\begin{tabular}{|c|c|c|c|c|c|c|c|}
\hline \multirow{2}{*}{ Épocas } & \multirow{2}{*}{ Cultivares } & \multicolumn{5}{|c|}{ Densidades (plantas $m^{-1}$ ) } & \multirow{2}{*}{ Médias } \\
\hline & & 10 & 15 & 20 & 25 & 30 & \\
\hline & IAC - 17 & $4,1^{1}$ & 3,3 & 2,8 & 2,6 & 2,3 & $3,0^{2} \mathrm{a}$ \\
\hline \multirow[t]{4}{*}{ Normal } & $I A C-12$ & 4,3 & 3,2 & 1,8 & 2,2 & 2,3 & $2,8 a$ \\
\hline & IAC - 19 & 3,3 & $\begin{array}{r}4,1 \\
\ldots \ldots\end{array}$ & 4,0 & 4,1 & 2,9 & $3,7 a$ \\
\hline & & & 0,3 & & $(\%)$ & & \\
\hline & IAC -17 & $2,2^{1}$ & 1,6 & 1,6 & 2,0 & 1,9 & $1,9^{2} \mathrm{a}$ \\
\hline \multirow[t]{2}{*}{ Tardia } & IAC -12 & 2,3 & 1,5 & 1,9 & 0,6 & 1,5 & $1,6 a$ \\
\hline & IAC -19 & 2,9 & 1,6 & 1,9 & 0,8 & 0,4 & $1,5 \mathrm{a}$ \\
\hline
\end{tabular}

${ }^{1}$ Dados transformados segundo $\sqrt{x}$.

${ }^{2}$ Médias seguidas por letras distintas na coluna diferem entre si pelo teste de Tukey a 0,05 de significância.

Enquanto na primeira época de semeadura o cultivar que apresentou maior valor médio de vagens com um grão foi o $\mid A C-19$, na segunda, 
apresentou o menor, sendo o maior valor constatado para o IAC-17 (Tabela 21). Os resultados apresentados nessa tabela revelam que, numericamente, da primeira para a segunda época de semeadura, houve redução no número de vagens da ordem de um grão para os cultivares IAC-17 e IAC-12 e de dois grãos para o cultivar IAC-19, ou de, 37,2\%, 42,8\% e 61,4\%, respectivamente.

$O$ teste $\mathrm{F}$ da análise conjunta revelou diferenças altamente significativas para o fator época. Da época de semeadura normal para a tardia, houve significativa redução no número de vagens contendo apenas um grão de soja (Tabela 22).

Tabela 22. Valores médios do número de vagens com um grão, em cinco densidades de plantas, observados nas épocas de semeadura normal e tardia.

\begin{tabular}{|c|c|c|c|c|c|c|}
\hline \multirow{2}{*}{ Épocas } & \multicolumn{5}{|c|}{ Densidades (plantas $m^{-1}$ ) } & \multirow{2}{*}{ Médias } \\
\hline & 10 & 15 & 20 & 25 & 30 & \\
\hline Normal & $3,9^{1}$ & 3,5 & 2,8 & 2,9 & $\overline{2,5}$ & $3,1^{2} a$ \\
\hline \multirow[t]{2}{*}{ Tardia } & 2,5 & 1,6 & 1,8 & 1,1 & 1,2 & 1,6 \\
\hline & & 0,1 & & (\%) & & \\
\hline
\end{tabular}

${ }^{1}$ Valores transformados segundo $\sqrt{x}$.

${ }^{2}$ Médias seguidas por letras distintas na coluna diferem entre si pelo teste de Tukey a 0,05 de significância.

Quando se analisou os níveis do fator densidade, a regressão polinomial revelou valores de $F$ altamente significativos para regressão linear, de maneira que, a medida que se aumentou a densidade de plantas, diminuiu o número de vagens com um grão e nesse caso, $94 \%$ da variação observada foi devido à densidade utilizada. A equação correspondente se encontra no Anexo B.

\subsubsection{Número de vagens com dois grãos}

Com relação aos cultivares na época de semeadura normal, o teste de Tukey revelou as diferenças apresentadas na Tabela 23. Na densidade de 10 
plantas. $\mathrm{m}^{-1}$, o cultivar IAC-12 produziu maior número de vagens contendo dois grãos que o cultivar IAC-19, sendo que este não diferiu significativamente do cultivar IAC-17, que por sua vez, não diferiu do IAC-12. Contudo, na densidade de 20 plantas $\mathrm{m}^{-1}$, o maior número de vagens com dois grãos foi produzido pelo cultivar IAC-19 e o menor pelo IAC-12, enquanto o IAC-17 não diferiu destes dois cultivares. Considerando-se a época de semeadura tardia, independente da densidade de plantas, o cultivar IAC-12 produziu menor número de vagens contendo dois grãos que os cultivares IAC-17 e IAC-19, que não diferiram entre si.

Tabela 23. Valores médios do número de vagens com dois grãos formadas pelos cultivares IAC-17, IAC-12 e IAC-19, em cinco densidades de plantas, observados em épocas de semeadura normal e tardia.

\begin{tabular}{|c|c|c|c|c|c|c|c|}
\hline \multirow{2}{*}{ Épocas } & \multirow{2}{*}{ Cultivares } & \multicolumn{5}{|c|}{ Densidades (plantas. $\mathrm{m}^{-1}$ ) } & \multirow{2}{*}{ Médias } \\
\hline & & 10 & 15 & 20 & 25 & 30 & \\
\hline & $I A C-17$ & $41,0^{1,2} a b$ & $25,5 a$ & $24,6 a b$ & $24,2 a$ & 25,3 a & 27,8 \\
\hline \multirow[t]{4}{*}{ Normal } & $I A C-12$ & 48,6 a & $27,5 a$ & $18,4 \quad b$ & 25,5 a & 23,4 a & 27,9 \\
\hline & $I A C-19$ & 32,0 & $27,3 a$ & 33,6 a & 23,3 a & 25,0 a & 28,1 \\
\hline & & & S. 0,87 & & C.V. (\%) & 14 & \\
\hline & $I A C-17$ & 31,3 & 21,5 & 18,6 & 20,3 & 16,3 & $21,3 a$ \\
\hline \multirow[t]{2}{*}{ Tardia } & IAC - 12 & 32,2 & 17,8 & 16,7 & 11,5 & 10,5 & $17,0 \mathrm{~b}$ \\
\hline & IAC - 19 & 33,6 & 29,1 & 21,5 & 18,3 & 9,7 & $21,6 a$ \\
\hline
\end{tabular}

${ }^{1}$ Dados transformados segundo $\sqrt{x}$.

${ }^{2}$ Médias seguidas por letras distintas na coluna diferem entre si pelo teste de Tukey a 0,05 de significância.

Da mesma forma observada para o número de vagens formadas por planta contendo apenas um grão, da época de semeadura normal para a época de semeadura tardia, todos os cultivares diminuíram o número de vagens contendo dois grãos (Tabela 23). 
Com relação à interação cultivar e densidade verificada na primeira época de semeadura, a análise de regressão polinomial revelou, por meio do desdobramento dos graus de liberdade, resposta quadrática dos efeitos do fator densidade dentro dos cultivares IAC-17 e IAC-12. Na época de semeadura tardia a análise de regressão polinomial para o fator densidade revelou respostas do tipo linear altamente significativas (Anexo $A$ ).

A análise estatística conjunta das épocas de semeadura realizada para a variável vagens com dois grãos detectou, através do teste $F$, interação entre os fatores época e densidade (Apêndice 3).

As médias para épocas, analisadas pelo teste de Tukey, são apresentadas na Tabela 24. Nesta, pode-se observar que, com exceção da densidade de 15 plantas. $\mathrm{m}^{-1}$, nas demais foram produzidas mais vagens com dois grãos na época de semeadura normal.

Tabela 24. Valores médios do número de vagens com dois grãos formadas por três cultivares de soja, em cinco densidade de plantas, observados nas épocas de semeadura normal e tardia.

\begin{tabular}{|c|c|c|c|c|c|c|c|c|c|}
\hline \multirow{2}{*}{ Épocas } & \multicolumn{8}{|c|}{ Densidades (plantas $m^{-1}$ ) } & \multirow{2}{*}{ Médias } \\
\hline & \multicolumn{2}{|l|}{10} & 15 & 20 & & 25 & & 30 & \\
\hline Normal & \multicolumn{2}{|c|}{$40,5^{1,2} a$} & 26,8 a & 25,5 & a & 24,3 & $a$ & $24,6 a$ & 27,9 \\
\hline \multirow[t]{2}{*}{ Tardia } & 32,4 & b & $22,8 a$ & 18,9 & $b$ & 16,7 & b & $12,2 \quad b$ & 20,0 \\
\hline & \multicolumn{4}{|c|}{ D.M.S. $\quad 0,44$} & & V.(\%) & 9,58 & & \\
\hline
\end{tabular}

${ }^{1}$ Dados transformados segundo $\sqrt{x}$.

${ }^{2}$ Médias seguidas por letras distintas na coluna diferem entre si pelo teste de Tukey a 0,05 de significância.

A análise de regressão do fator densidade, constatou o efeito quadrático para a época de semeadura normal e linear para a época tardia. Verificou-se também, através das equações polinomiais do Anexo B, que aproximadamente $93 \%$ e $96 \%$ das vagens produzidas com dois grãos, respectivamente para as épocas normal e tardia, foram decorrentes das densidades utilizadas. 


\subsubsection{Número de vagens com três grãos}

As diferenças significativas reveladas pelo teste de Tukey para as médias de vagens formadas com três grãos pelos cultivares IAC-17, IAC-12 e IAC-19, em cinco densidades de plantas, observados em épocas de semeadura normal e tardia, são apresentadas na Tabela 25.

Tabela 25. Valores médios do número de vagens com três grãos formadas pelos cultivares IAC-17, IAC-12 e IAC-19, em cinco densidades de plantas, observados em épocas de semeadura normal e tardia.

\begin{tabular}{|c|c|c|c|c|c|c|c|}
\hline \multirow{3}{*}{ Épocas } & \multirow{3}{*}{$\frac{\text { Cultivares }}{\text { IAC - } 17}$} & \multicolumn{5}{|c|}{ Densidades (plantas $m^{-1}$ ) } & \multirow{2}{*}{ - Médias } \\
\hline & & 10 & 15 & 20 & 25 & 30 & \\
\hline & & $6,0^{1,2} \mathrm{~b}$ & $4,3 \quad b$ & 4,9 a & $4,1 \quad b$ & $4,7 \quad b$ & 4,8 \\
\hline \multirow[t]{4}{*}{ Normal } & IAC - 12 & 22,3 a & 12,2 a & 8,0 a & 11,0 a & 10,2 a & 12,7 \\
\hline & IAC - 19 & $7,5 \mathrm{~b}$ & $6,2 b$ & 7,6 a & $5,1 \quad b$ & $6,3 a b$ & 6,5 \\
\hline & & D.N & S. 0,77 & & V. (\%) 13 & & \\
\hline & $I A C-17$ & 18,6 & 13,6 & 11,3 & 10,9 & 8,9 & $12,7 \quad b$ \\
\hline \multirow[t]{3}{*}{ Tardia } & $I A C-12$ & 37,5 & 22,8 & 20,2 & 14,9 & 12,0 & $20,5 a$ \\
\hline & IAC - 19 & 17,5 & 15,8 & 12,6 & 10,5 & 6,1 & $12,5 b$ \\
\hline & & \multicolumn{2}{|c|}{ D.M.S. $\quad 0,44$} & & V. (\%) 12 & & \\
\hline
\end{tabular}

${ }^{1}$ Dados transformados segundo $\sqrt{x}$.

${ }^{2}$ Médias seguidas por letras distintas na coluna diferem entre si pelo teste de Tukey a 0,05 de significância.

Na primeira época de semeadura o teste comparativo de médias revelou diferenças significativas entre cultivares nas densidades de 10,15 e 25 plantas. $\mathrm{m}^{-1}$, com o cultivar IAC-12 produzindo maior número de vagens contendo três grãos por planta, que os cultivares $\mid A C-17$ e $\mid A C-19$, que não diferiram entre si. Diferenças significativas também foram detectadas na densidade de 30 plantas. $\mathrm{m}^{-1}$, na qual o cultivar IAC-12 produziu maior número de vagens contendo três grãos e o cultivar IAC-17 menor, com o cultivar IAC-19 não diferindo de ambos. Na semeadura em época tardia, independente da 
densidade considerada, o cultivar IAC-12 também produziu maior quantidade de vagens com três grãos que os outros dois cultivares que não diferiram entre si.

Ao contrário dos fatos observados para o número de vagens formados por planta contendo um e dois grãos, da época de semeadura normal para a época de semeadura tardia, os três cultivares aumentaram o número de vagens contendo três grãos. Em média, o cultivar IAC-17 aumentou em 160,4\%, o cultivar IAC-12 em 67,5\% e o IAC-19 em 86,2\%.

Para o fator densidade, a análise de regressão polinomial revelou efeito altamente significativo e quadrático somente para o cultivar IAC-12 na época de semeadura normal. Neste caso, aproximadamente $90 \%$ da variação observada foi devida ao fator densidade, sendo explicada pela expressão $y=0,00967 x^{2}$ $0,45159 x+8,19101$. Para a época de semeadura tardia, independente do cultivar, a análise de regressão polinomial revelou efeito linear altamente significativo, expresso pela equação $y=-0,08983 x+5,64553$.

Quando se realizou a análise conjunta das épocas de semeadura normal e tardia, o teste $F$ detectou valores altamente significativos para a interação entre época e densidade. Na Tabela 26 são apresentados os valores médios do número de vagens com três grãos formadas nas duas épocas de semeadura. Verificam-se diferenças significativas entre cultivares nas densidades de 10,15, 20 e 25 plantas. $\mathrm{m}^{-1}$, onde na época normal os cultivares produziram menor número de vagens contendo três grãos por planta.

Com relação ao fator densidade, a regressão polinomial revelou efeito significativamente quadrático na época de semeadura normal e efeito altamente significativo e linear na época de semeadura tardia, cujas respectivas equações de regressão são apresentadas no Anexo B. 
Tabela 26. Valores médios do número de vagens com três grãos, em cinco densidades de plantas, observados em épocas de semeadura normal e tardia.

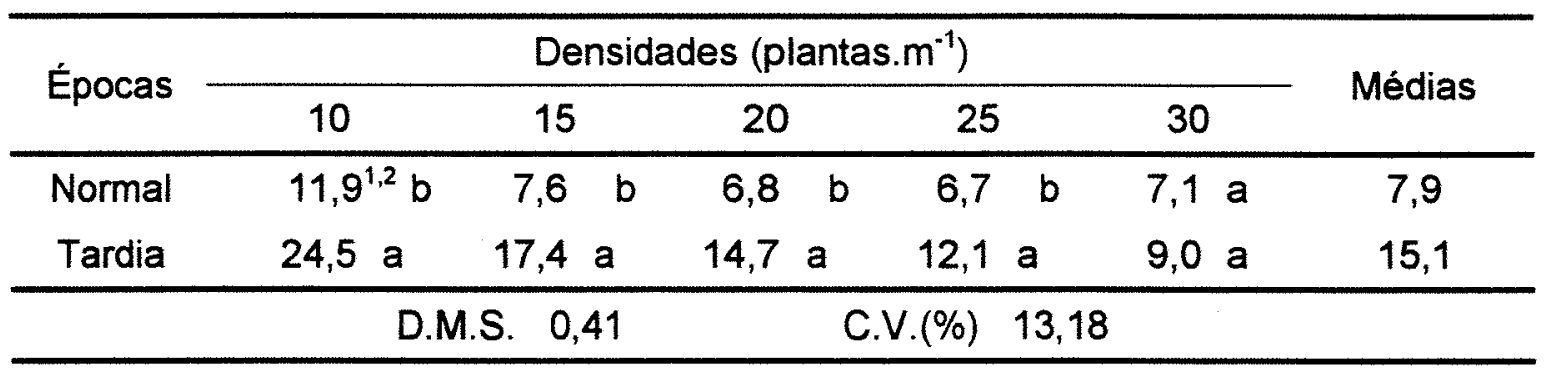

${ }^{1}$ Dados transformados segundo $\sqrt{x}$.

${ }^{2}$ Médias seguidas por letras distintas na coluna diferem entre si pelo teste de Tukey a 0,05 de significância.

\subsection{Número total de vagens}

As médias do número total de vagens por planta observadas nas épocas de semeadura normal e tardia, são apresentadas na Tabela 27.

Tabela 27. Valores médios do número total de vagens formadas por planta dos cultivares IAC-17, IAC-12 e IAC-19, em cinco densidades de plantas, observados em épocas de semeadura normal e tardia.

\begin{tabular}{|c|c|c|c|c|c|c|c|}
\hline \multirow{2}{*}{ Épocas } & \multirow{2}{*}{ Cultivares } & \multicolumn{5}{|c|}{ Densidades (plantas. $m^{-1}$ ) } & \multirow{2}{*}{ Médias } \\
\hline & & 10 & 15 & 20 & 25 & 30 & \\
\hline & IAC - 17 & $62,8^{1,2 b}$ & $43,1 \mathrm{a}$ & $38,8 a b$ & $37,0 \mathrm{a}$ & $40,3 a$ & 44,4 \\
\hline \multirow[t]{4}{*}{ Normal } & $\mid A C-12$ & $82,2 \mathrm{a}$ & $47,6 \mathrm{a}$ & $30,6 \mathrm{~b}$ & $42,1 \mathrm{a}$ & $41,4 a$ & 48,8 \\
\hline & $I A C-19$ & $48,8 \mathrm{~b}$ & $42,9 a$ & $53,0 \mathrm{a}$ & $40,9 a$ & $44,9 a$ & 46,1 \\
\hline & & D.N & S. 1,07 & & C.V. (\%) & 7,86 & \\
\hline & $\mathrm{IAC}-17$ & 57,7 & 41,6 & 35,9 & 37,9 & 31,2 & $40,9 a$ \\
\hline \multirow[t]{2}{*}{ Tardia } & $I A C-12$ & 77,8 & 47,6 & 42,0 & 32,7 & 25,8 & $45,2 \mathrm{a}$ \\
\hline & IAC - 19 & 63,5 & 54,3 & 44,4 & 36,2 & 21,4 & $44,0 a$ \\
\hline
\end{tabular}

${ }^{1}$ Dados transformados segundo $\sqrt{x}$.

${ }^{2}$ Médias seguidas por letras distintas na coluna diferem entre si pelo teste de Tukey a 0,05 de significância. 
Os três cultivares de soja, quando semeados em época normal nas densidades de 15,25 e 30 plantas. $\mathrm{m}^{-1}$ produziram, estatisticamente, o mesmo número de vagens. Entretanto, diferenças foram observadas nas demais densidades; na de 10 plantas. $\mathrm{m}^{-1}$, o cultivar IAC-12 apresentou maior número de vagens que os cultivares IAC-17 e IAC-19 que não diferiram entre si; de forma contrária, na densidade de 20 plantas. $\mathrm{m}^{-1}$, a maior produção de vagens foi observada no cultivar IAC-19 e a menor no IAC-12, sendo que o IAC-17 não diferiu desses dois (Tabela 27).

O maior número de vagens produzido por planta do cultivar IAC-12 na primeira época semeadura, quando em baixas densidades (10 plantas. $\mathrm{m}^{-1}$ ), ocorreu devido a maior produção de vagens com dois e três grãos, verificados neste cultivar quando comparado aos outros, na mesma densidade de plantas (Tabelas 23, 25 e 27). As diferenças estatísticas verificadas na densidade de 20 plantas $\mathrm{m}^{-1}$, também podem ser relacionadas com o número de vagens chochas, número de vagens com um e dois grãos produzidos por esses cultivares (Tabelas 19, 21, 23 e 27). Nestas tabelas e nesta mesma densidade se observa que o cultivar IAC-19 produziu maior número de vagens chochas, junto com o cultivar IAC-17 e maior número de vagens com um grão, quando comparado com os demais cultivares, enquanto no cultivar IAC-12 foram observados menor número de vagens chochas e de vagens com dois grãos produzidos por planta.

Nas densidades de 15 e 25 plantas. $\mathrm{m}^{-1}$ o maior número de vagens chochas produzido pelo cultivar IAC-17, o maior número de vagens com três grãos verificado no cultivar IAC-12 e o maior número de vagens com um grão no cultivar IAC-19, fizeram com que estes três cultivares não apresentassem diferenças significativas quanto ao número de vagens produzidas por planta, na primeira época de semeadura (Tabelas 19, 21, 25 e 27). Na densidade de 30 plantas. $\mathrm{m}^{-1}$, essa igualdade estatística ocorreu porque 0 cultivar IAC-17 produziu número de vagens chochas que não diferiu do outros dois cultivares e menor número de vagens com três grãos, enquanto que o cultivar IAC-12 
produziu menos vagens chochas e maior número de vagens com três grãos quando comparado com os demais, enquanto que o cultivar IAC-19 produziu mais vagens chochas e valor intermediário de vagens com três grãos (Tabelas 19,25 e 27 ).

Da primeira época de semeadura para a segunda verificou-se que em média, houve diminuição no número de vagens produzidos pelos cultivares de soja (Tabela 27). Por outro lado, na época de semeadura tardia, os cultivares não apresentaram diferenças estatísticas entre eles, fato este, diretamente relacionado com o número diferenciado de grãos por vagem. Neste caso, o cultivar IAC-17 mesmo não diferindo do IAC-12 e IAC-19 quanto ao número de vagens chochas produzidas por planta, produziu maior número de vagens com dois grãos juntamente com o IAC-19 e não diferiu estatisticamente no número de vagens com três grãos produzido pelo IAC-19, ambos inferiores ao produzido pelo IAC-12, resultando assim, em número igual de vagens por planta (Tabelas 19, 23, 25 e 27). Com relação ao IAC-12, a igualdade estatística em relação ao número total de vagens dos outros cultivares, foi devido ao menor número de vagens chochas produzidas e maior número de vagens com três grãos (Tabelas 19, 25 e 27).

Para as densidades, realizou-se a análise de regressão polinomial, na qual as médias foram ajustadas por equações de regressão do tipo quadrática para os cultivares IAC-17 e IAC-12 na época de semeadura normal e linear para a segunda época de semeadura. A variação desta característica devido a densidade foi da ordem de $98 \%$ e $90 \%$ nos cultivares IAC-17 e IAC-12, respectivamente (Anexo $A$ ).

$\mathrm{Na}$ época de semeadura tardia, independente do cultivar, ao se aumentar a densidade de plantas na linha de semeadura, diminuiu-se o número total de vagens produzidas pelos mesmos, de acordo com a equação $y=-0,1402 x+$ 9,2966 , cujo coeficiente de determinação é igual a $96,4 \%$, confirmando os resultados obtidos por Lam-Sanchez \& Veloso (1974a), Queiroz (1975), Rosolem et al. (1983) e Marcos Filho \& Novembre (1990). 
A análise da variância conjunta das épocas de semeadura, mostrou valores altamente significativos da interação época e densidade.

Como se observa na Tabela 28 , na maioria das densidades estudadas não houve diferenças estatísticas quanto ao número de vagens produzidas pelos cultivares de soja nas duas épocas de semeadura, exceto na densidade de 30 plantas $\mathrm{m}^{-1}$, onde se verificou superioridade desta característica na época de semeadura normal.

Tabela 28. Valores médios do número total de vagens produzidas, em cinco densidades de plantas, observados em épocas de semeadura normal e tardia.

\begin{tabular}{ccccccccc}
\hline \multirow{2}{*}{ Épocas } & \multicolumn{7}{c}{ Densidades (plantas. $\mathrm{m}^{-1}$ ) } & \multirow{2}{*}{ Médias } \\
\cline { 2 - 7 } & 10 & 15 & 20 & 25 & 30 & \\
\hline Normal & $64,6^{1,2}$ a & 44,5 a & 40,8 a & 40,0 a & 42,2 a & 45,8 \\
Tardia & 66,3 & a & 47,8 a & 40,8 a & 35,6 a & 26,1 & b & 42,2 \\
\hline \multicolumn{6}{c}{ D.M.S. 0,60} & \multicolumn{5}{c}{ C.V. (\%) } & 9,64 & & \\
\hline
\end{tabular}

${ }^{1}$ Dados transformados segundo $\sqrt{x}$.

${ }^{2}$ Médias seguidas por letras distintas na coluna diferem entre si pelo teste de Tukey a 0,05 de significância.

$O$ teste $F$ da regressão polinomial relativa aos cinco niveis do fator densidade, revelou significância a 0,01 para as duas épocas de semeadura. As equaçōes ajustadas são do tipo quadrática para a primeira época e do tipo linear para a segunda, como ilustra a Figura 3. 


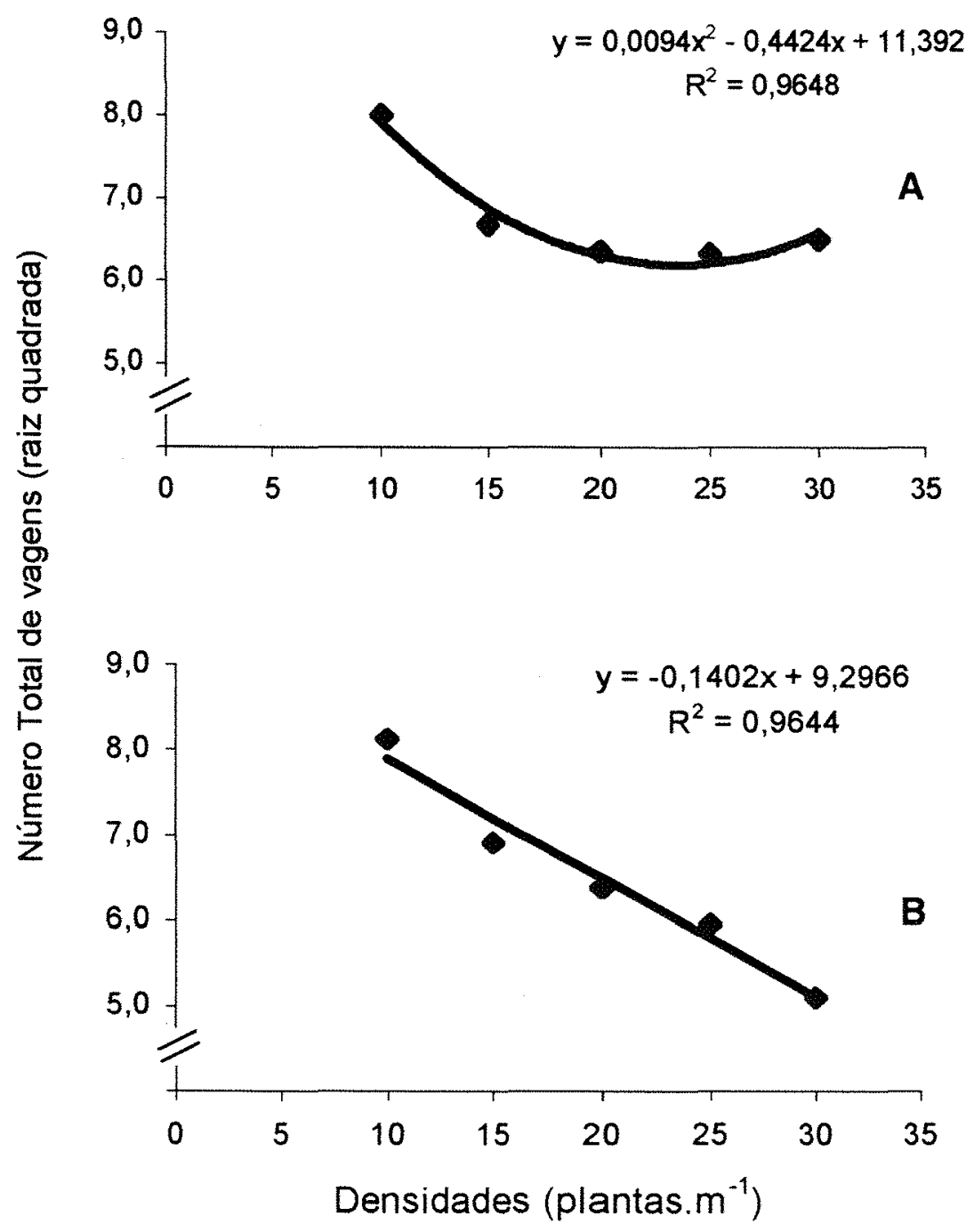

Figura 3. Variação no número total de vagens formadas por planta de soja em função das densidades de plantas nas épocas de semeadura normal (A) e tardia (B).

\subsection{Número total de grãos}

As médias do número total de grãos produzidos pelos cultivares de soja na primeira época de semeadura, visualizadas na Tabela 29 e analisadas pelo teste de Tukey, apresentaram diferença significativa apenas na densidade de 10 plantas. $\mathrm{m}^{-1}$, na qual o cultivar IAC-12 foi superior ao IAC-17 e IAC-19, os 
quais não diferiram entre si. Nas demais densidades estudadas, os cultivares apresentaram número total de grãos semelhantes, não diferindo entre si.

Tabela 29. Valores médios do número total de grãos produzidos por planta dos cultivares de soja IAC-17, IAC-12 e IAC-19, em cinco densidades de plantas, observados em épocas de semeadura normal e tardia.

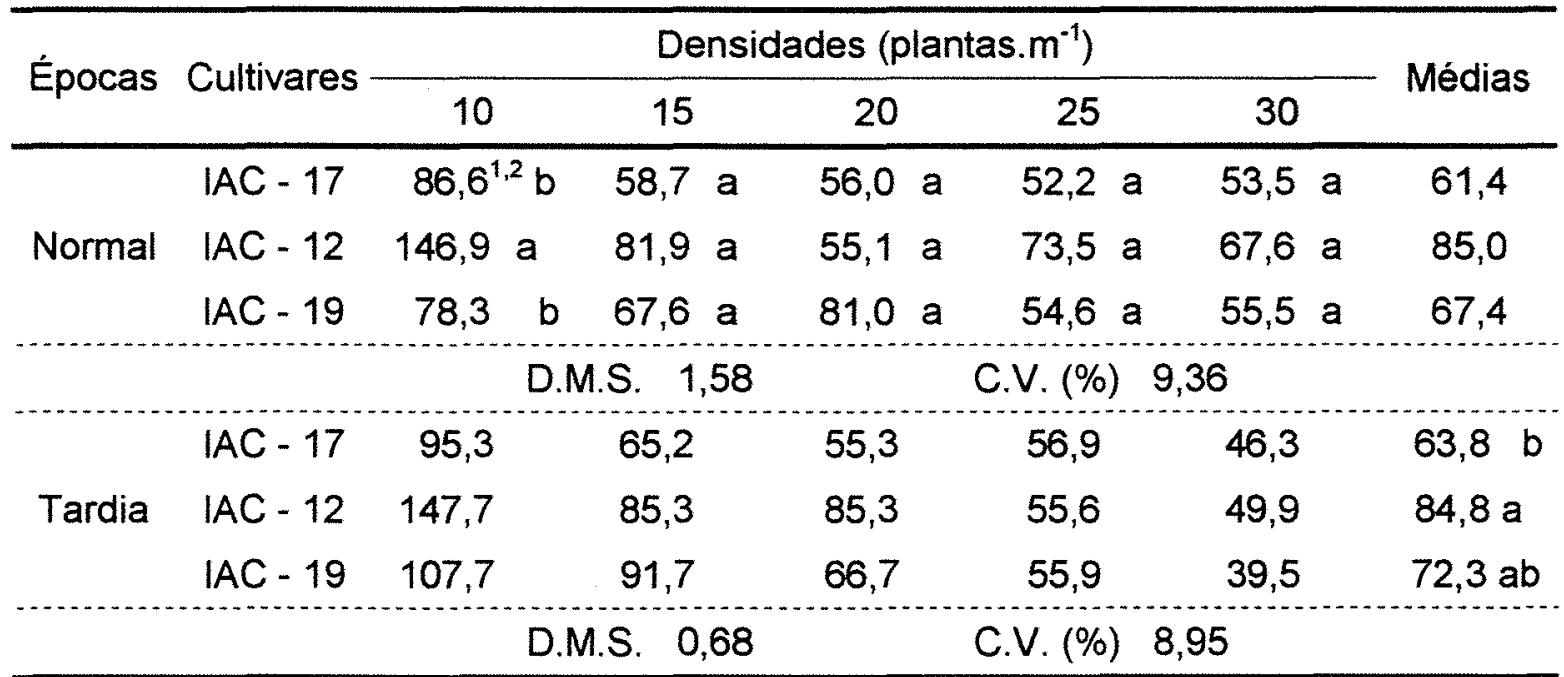

${ }^{1}$ Dados transformados segundo $\sqrt{x}$.

${ }^{2}$ Médias seguidas por letras distintas na coluna diferem entre si pelo teste de Tukey a 0,05 de significância.

Em relação ao número total de grãos produzido pelos cultivares $I A C-17$, IAC-12 e IAC-19 na época de semeadura tardia (Tabela 29), verifica-se que, independente da densidade de plantas, o cultivar IAC-12 produziu maior número de grãos que o IAC-17, enquanto o IAC-19 não diferiu desses dois cultivares.

Quando se analisou o fator densidade através da regressão polinomial, as médias do número total de grãos produzidos na época de semeadura normal pelos cultivares de soja IAC-17 e IAC-12 foram ajustadas por equações quadráticas (Anexo A). Na época de semeadura tardia as variações observadas também foram ajustadas por equações quadráticas (Anexo A). Queiroz (1975) e Rosolem et al. (1983) observaram diminuição no número de grãos formados por planta com o aumento da densidade de plantas. 
$\mathrm{Na}$ análise conjunta das épocas de semeadura, o teste $\mathrm{F}$ revelou interação entre os fatores época e densidade $(P<0,05)$. As diferenças estatísticas detectadas pelo teste de Tukey quanto ao número total de grãos, nas cinco densidades estudadas e nas duas épocas de semeadura, são apresentadas na Tabela 30.

Tabela 30. Valores médios do número total de grãos produzidos por planta de soja, em cinco densidades de plantas, observados nas épocas de semeadura normal e tardia.

\begin{tabular}{|c|c|c|c|c|c|c|c|}
\hline \multirow{2}{*}{ Épocas } & \multicolumn{6}{|c|}{ Densidades (plantas $m^{-1}$ ) } & \multirow{2}{*}{ Médias } \\
\hline & 10 & 15 & 20 & 25 & 30 & & \\
\hline Normal & $103,9^{1,2}$ & 69,4 a & 64,0 a & 60,1 a & 58,9 & a & 70,0 \\
\hline Tardia & 116,9 & $80,7 a$ & 69,1 a & 56,1 a & 45,2 & b & 71,5 \\
\hline
\end{tabular}

${ }^{1}$ Dados transformados segundo $\sqrt{x}$.

${ }^{2}$ Médias seguidas por letras distintas na coluna diferem entre si pelo teste de Tukey a 0,05 de significância.

$\mathrm{Na}$ Tabela 30 verifica-se que o número de grãos produzidos por planta de soja nas diferentes densidades não foi significativo para as épocas de semeadura normal e tardia, exceto na densidade de 30 plantas $\mathrm{m}^{-1}$, onde a época de semeadura normal apresentou maior número de grãos do que a época tardia.

O desdobramento dos graus de liberdade da análise de regressão polinomial revelou efeito quadrático das densidades na primeira época de semeadura e linear na segunda. As variações observadas no número total de grãos são explicadas, respectivamente, por $95 \%$ e $96 \%$ das variações nas densidades (Anexo B). 


\subsection{Acamamento}

O acamamento verificado nos cultivares de soja IAC-17, IAC-12 e IAC-19 não apresentou grande variação, não justificando a análise estatística destes dados.

$\mathrm{Na}$ Tabela 31, são apresentados os valores médios de acamamento nas cinco densidades de plantas estudadas, observados nos três cultivares de soja quando semeados em épocas normal e tardia.

Tabela 31. Valores médios de acamamento nos cultivares de soja IAC-17, IAC-12 e IAC-19, em cinco densidades de plantas, observados nas épocas de semeadura normal e tardia.

\begin{tabular}{|c|c|c|c|c|c|c|}
\hline \multirow{2}{*}{ Épocas } & \multirow{2}{*}{ Cultivares } & \multicolumn{5}{|c|}{ Densidades (plantas $\mathrm{m}^{-1}$ ) } \\
\hline & & 10 & 15 & 20 & 25 & 30 \\
\hline \multirow{3}{*}{ Normal } & IAC -17 & 1 & 1 & 1 & 2 & 2 \\
\hline & $I A C-12$ & 1 & 1 & 1 & 2 & 1 \\
\hline & IAC - 19 & 2 & 2 & 2 & 2 & 2 \\
\hline \multirow{3}{*}{ Tardia } & $I A C-17$ & 1 & 1 & 1 & 1 & 1 \\
\hline & $I A C-12$ & 1 & 1 & 1 & 1 & 1 \\
\hline & $I A C-19$ & 1 & 1 & 1 & 1 & 1 \\
\hline
\end{tabular}

O cultivar IAC-19 apresentou maiores valores de acamamento nas cinco densidades de plantas estudadas, na época de semeadura normal (Tabela 31). Este fato, talvez seja conseqüência da maior altura final de plantas alcançada por este cultivar, nesta época de semeadura (Tabela 9).

De maneira geral, os cultivares se mostraram resistentes ao acamamento, principalmente na época de semeadura tardia, confirmando os resultados obtidos por Lam-Sanchez \& Veloso (1974b) e contrariando as informações obtidas por Reis et al. (1977). 


\subsection{Massa de 1000 grãos}

O teste de Tukey revelou diferenças entre cultivares independente do fator densidade, de maneira que, na primeira época de semeadura, o cultivar IAC-19 formou grãos com maior quantidade de massa que o cultivar IAC-17 e este, foi significativamente superior ao cultivar IAC-12 (Tabela 32). Apenas 0 cultivar IAC-12 formou grãos com massa semelhante ao descrito na Tabela 2 para esse cultivar, sendo maiores as massas dos grãos dos cultivares IAC-17 e IAC-19, o que mostra talvez, as condições favoráveis dessa época de semeadura para esses dois cultivares, quando se considera esta característica.

Tabela 32. Valores médios da massa de 1000 grãos $(\mathrm{g})$ produzidos pelos cultivares de soja IAC-17, IAC-12 e IAC-19, em cinco densidades de plantas, observados em épocas de semeadura normal e tardia .

\begin{tabular}{|c|c|c|c|c|c|c|c|}
\hline \multirow{2}{*}{ Épocas } & \multirow{2}{*}{ Cultivares } & \multicolumn{5}{|c|}{ Densidades (plantas. $\mathrm{m}^{-1}$ ) } & \multirow{2}{*}{ Médias } \\
\hline & & 10 & 15 & 20 & 25 & 30 & \\
\hline & $I A C-17$ & 167,1 & 170,0 & 166,6 & 167,0 & 166,8 & $167,5^{1} \mathrm{~b}$ \\
\hline \multirow[t]{4}{*}{ Normal } & $I A C-12$ & 148,0 & 141,1 & 148,9 & 146,5 & 146,4 & $146,2 \quad c$ \\
\hline & $I A C=19$ & 176,1 & 178,9 & 183,7 & 178,5 & 179,8 & $179,4 a$ \\
\hline & \multicolumn{4}{|c|}{ D.M.S. 5,30} & C.V. $(\%)$ & 3,57 & \\
\hline & $I A C-17$ & 151,8 & 160,5 & 163,4 & 164,6 & 167,4 & $161,5 \mathrm{a}$ \\
\hline \multirow[t]{2}{*}{ Tardia } & IAC - 12 & 118,8 & 120,7 & 124,7 & 121,8 & 120,5 & $121,3 \quad \mathrm{c}$ \\
\hline & IAC -19 & 148,6 & 149,5 & 150,7 & 148,3 & 150,6 & 149,6 b \\
\hline
\end{tabular}

Médias seguidas por letras distintas na coluna diferem entre si pelo teste de Tukey a 0,05 de significância.

A densidade de plantas também não influenciou a massa de 1000 grãos produzidos pelos cultivares de soja estudados, na época de semeadura tardia, como observado por Val et al. (1971). Por outro lado, resultados contrários a estes foram encontrados por Nakagawa et al. (1986a) e Nakagawa et al. (1987). Entretanto, nesta época, o cultivar IAC-17 superou estatisticamente o cultivar 
IAC-19 e este, o IAC-12 (Tabela 32). O cultivar IAC-17 apresentou na média das densidades, massa de grãos superior a descrita para esse cultivar, enquanto que os cultivares IAC-12 e IAC-19 formaram grãos mais leves que 0 descrito para esses cultivares (Tabela 2).

$\mathrm{Na}$ análise conjunta das épocas de semeadura o teste $\mathrm{F}$ revelou interação tripla altamente significativa entre os fatores época, cultivar $e$ densidade.

$\mathrm{Na}$ Tabela 33 verifica-se que o cultivar IAC-17 apresentou diferenças estatísticas apenas nas densidades de 10 e 15 plantas. $\mathrm{m}^{-1}$, onde a maior massa de 1000 grãos foi obtida na época de semeadura normal. Estas diferenças, com superioridade na época de semeadura normal, também foram observadas para os cultivares IAC-12 e IAC-19, porém, em todas as densidades estudadas, mostrando ter ocorrido, provavelmente, maior formação e translocação de fotoassimilados nessa época.

Tabela 33. Valores médios da massa de 1000 grãos $(\mathrm{g})$ produzidos pelos cultivares (Cvs.) de soja IAC-17, IAC-12 e IAC-19, em cinco densidades de plantas, observados nas épocas de semeadura normal e tardia.

\begin{tabular}{|c|c|c|c|c|c|c|c|c|c|}
\hline \multirow{2}{*}{ Cvs. } & \multirow{2}{*}{$E^{1}$} & \multicolumn{7}{|c|}{ Densidades (plantas $\mathrm{m}^{-1}$ ) } & \multirow{2}{*}{ Médias } \\
\hline & & 10 & 15 & & 20 & 25 & & 30 & \\
\hline \multirow{2}{*}{ IAC -17} & $N$ & $167,1^{2} a$ & 170,0 & $\bar{a}$ & 166,6 a & 167,0 & $a$ & 166,8 a & 167,5 \\
\hline & $T$ & 151,8 & 160,5 & b & $163,4 a$ & 164,6 & a & 167,4 a & 161,5 \\
\hline \multirow{2}{*}{ IAC -12} & $N$ & 148,0 a & 141,1 & a & 148,9 a & 146,5 & a & 146,4 a & 146,2 \\
\hline & $T$ & 118,8 & b 120,7 & $b$ & $124,7 \quad b$ & 121,8 & $b$ & $120,5 \quad b$ & 121,3 \\
\hline \multirow{2}{*}{ IAC -19} & $N$ & $176,1 \mathrm{a}$ & 178,9 & a & 183,7 a & 178,5 & a & 179,8 a & 179,4 \\
\hline & $T$ & 148,6 & 149,5 & b & $150,7 \quad b$ & 148,3 & b & $150,6 \quad b$ & 149,6 \\
\hline
\end{tabular}

Epocas de semeadura: $\mathrm{N}=$ normal e $\mathrm{T}=$ tardia.

${ }^{2}$ Médias seguidas por letras distintas na coluna diferem entre si pelo teste de Tukey a 0,05 de significância. 
Com relação a densidade de plantas, a análise de regressão polinomial não revelou diferenças significativas entre os cultivares na época de semeadura normal porém, na época de semeadura tardia, valores de $F$ altamente significativos foram detectados no cultivar IAC-17. A equação $y=0,706 x+$ 147,42 ajustou as médias da massa de 1000 grãos desse cultivar. Através dessa equação pode-se afirmar que a medida que se aumentou a densidade de 10 até 30 plantas. $\mathrm{m}^{-1}$, houve aumento médio na massa de grãos da ordem de $0,71 \mathrm{~g}$ por planta de soja.

\subsection{Rendimento}

$\mathrm{Na}$ Tabela 34, observam-se as médias de rendimento $\left(\mathrm{kg}_{\mathrm{gha}} \mathrm{h}^{-1}\right)$ dos cultivares de soja IAC-17, IAC-12 e IAC-19, em cinco densidades de plantas em épocas de semeadura normal e tardia. Independente da densidade utilizada, os cultivares IAC-12 e IAC-19 foram mais produtivos que o IAC-17, na primeira época de semeadura, enquanto que não se verificou diferenças estatísticas entre os rendimentos obtidos nas diferentes densidades de plantas nos três cultivares estudados, na segunda época de semeadura.

O cultivar IAC-17 na época de semeadura normal, quando comparado aos outros dois cultivares, produziu em média, maior número de vagens chochas, número semelhante de vagens com dois grãos ao IAC-12 e menor número de vagens com três grãos (Tabelas 19, 23 e 25), refletindo na menor produção de vagens pelas plantas deste cultivar. Verificou-se também, que na média das cinco densidades de plantas, o cultivar IAC-17 produziu menor número de grãos por planta e atingiu valor intermediário quando comparado ao IAC-12 e IAC-19, para a massa de 1000 grãos (Tabelas 29 e 32).

Dessa maneira, conclui-se que a associação do menor número de grãos por planta com a menor massa dos grãos refletiram no menor rendimento do cultivar IAC-17 na época de semeadura normal (Tabela 34). 
Tabela 34. Valores médios do rendimento de grãos $\left(\mathrm{kg} \cdot \mathrm{ha}^{-1}\right)$ obtidos pelos cultivares de soja IAC-17, IAC-12 e IAC-19, em cinco densidades de plantas, observados em épocas de semeadura normal e tardia.

\begin{tabular}{|c|c|c|c|c|c|c|c|}
\hline \multirow{2}{*}{ Épocas } & \multirow{2}{*}{ Cultivares } & \multicolumn{5}{|c|}{ Densidades (plantas. $\mathrm{m}^{-1}$ ) } & \multirow{2}{*}{ Médias } \\
\hline & & 10 & 15 & 20 & 25 & 30 & \\
\hline & $I A C-17$ & 2928,7 & 2919,3 & 2701,4 & 2808,0 & 2851,2 & $2841,7^{1} b$ \\
\hline \multirow[t]{4}{*}{ Normal } & $I A C-12$ & 3613,7 & 3045,9 & 3548,9 & 3394,9 & 2986,0 & 3317,9 a \\
\hline & IAC - 19 & 3181,3 & 3366,6 & 2951,2 & 3059,4 & 3407,2 & 3193,1 a \\
\hline & & D.M. & 328,70 & & C.V. (\%) & 11,66 & \\
\hline & IAC -17 & 2784,2 & 3506,1 & 3646,8 & 3147,6 & 2381,6 & $3093,3 a$ \\
\hline \multirow[t]{3}{*}{ Tardia } & $I A C-12$ & 3049,9 & 3158,2 & 3743,2 & 3271,6 & 3703,5 & 3385,3 a \\
\hline & $I A C-19$ & 3508,5 & 3978,9 & 3584,3 & 3169,5 & 3407,8 & 3529,8 a \\
\hline & & D.M. & 549,97 & & C.V. $(\%)$ & 18,23 & \\
\hline
\end{tabular}

Médias seguidas por letras distintas na coluna diferem entre si pelo teste de Tukey a 0,05 de significância.

Os cultivares IAC-12 e IAC-19 apesar de apresentaram número e massa de grãos diferentes (Tabelas 29 e 32), atingiram rendimento final semelhante (Tabela 34), superando o cultivar IAC-17. Isto pode ser explicado pelo fato do cultivar IAC-12 ter produzido menor número de vagens chochas, maior número de vagens com três grãos e consequentemente maior número total de grãos (Tabelas 19, 25 e 29) enquanto que, o cultivar IAC-19 apresentou maior número de vagens com dois grãos e apesar de ter produzido número total de grãos intermediário entre os outros dois cultivares, estes foram mais pesados (Tabelas 23, 29 e 32). Deste modo, o maior número de grãos, porém, mais leves, produzidos pelo cultivar IAC-12 e o menor número de grãos, porém, mais pesados, verificados no cultivar IAC-19, resultaram nos rendimentos semelhantes desses dois cultivares (Tabela 34).

$\mathrm{Na}$ segunda época de semeadura, os cultivares produziram o mesmo número de vagens, apresentando diferenças no número de grãos por planta (Tabelas 27 e 29). O cultivar IAC-17 produziu menor número de grãos, porém estes foram mais pesados que os dos outros cultivares (Tabela 32). O IAC-12 
teve um desempenho semelhante ao da época normal, ou seja, produziu maior número de grãos com menor massa (Tabelas 29 e 32). Com relação ao IAC-19, este apresentou número e massa de grãos com valores intermediários quando comparado com estas variáveis dos demais cultivares. Essas associações entre os componentes da produção justificam a ausência de diferenças significativas entre os cultivares para o fator rendimento.

Com relação à análise conjunta das épocas de semeadura, o teste $F$ revelou valores significativos $(P<0,05)$ para o fator época. $O$ teste de Tukey revelou que independente da densidade, a época de semeadura tardia proporcionou maiores rendimentos quando comparada com a época normal, como pode ser observado na Tabela 35.

Tabela 35. Valores médios do rendimento de grãos $\left(\mathrm{kg}_{\text {.ha }}{ }^{-1}\right)$ de soja em cinco densidades de plantas observados nas épocas de semeadura normal e tardia.

\begin{tabular}{ccccccc}
\hline \multirow{2}{*}{ Épocas } & \multicolumn{5}{c}{ Densidades $\left(\right.$ plantas. m $^{-1}$ ) } & \multirow{2}{*}{ Médias } \\
\cline { 2 - 6 } & 10 & 15 & 20 & 25 & 30 & \\
\hline Normal & 3241,2 & 3110,6 & 3067,2 & 3087,4 & 3081,5 & $3117,6^{1} \mathrm{~b}$ \\
Tardia & 3114,2 & 3547,7 & 3658,1 & 3196,2 & 3164,3 & $3336,1 \mathrm{a}$ \\
\hline \multicolumn{6}{c}{ D.M.S. 211,74} & \multicolumn{3}{c}{ C.V. (\%) } & 15,52 & \\
\hline
\end{tabular}

Médias seguidas por letras distintas na coluna diferem entre si pelo teste de Tukey a 0,05 de significância.

$\mathrm{Na}$ análise conjunta das épocas de semeadura, observam-se menores rendimentos na época de semeadura normal, apesar desta época ser a recomendada para a semeadura da soja, na qual os cultivares podem expressar suas qualidades. O cultivar IAC-17 foi o responsável pela diferença estatística, uma vez que este cultivar apresentou menor rendimento que os outros cultivares nesta época. 


\section{CONCLUSÕES}

a) O atraso da época de semeadura nem sempre diminui o rendimento da soja.

b) O rendimento de grãos não varia com a densidade de plantas, independentemente das combinações de cultivares com épocas de semeadura.

c) Os cultivares IAC-12 e IAC-19 apresentam melhor desempenho para rendimento de grãos em semeadura normal, independente das densidades.

d) Os cultivares não apresentam desempenho diferenciado para rendimento de grãos na combinação de época de semeadura tardia com densidade.

e) Dentre os cultivares, destaca-se o IAC-12 pelo menor chochamento das vagens e pela formação de maior quantidade de vagens contendo três grãos.

f) O componente da produção número de grãos por planta é o que mais contribui para a compensação de rendimento. 
ANEXOS 


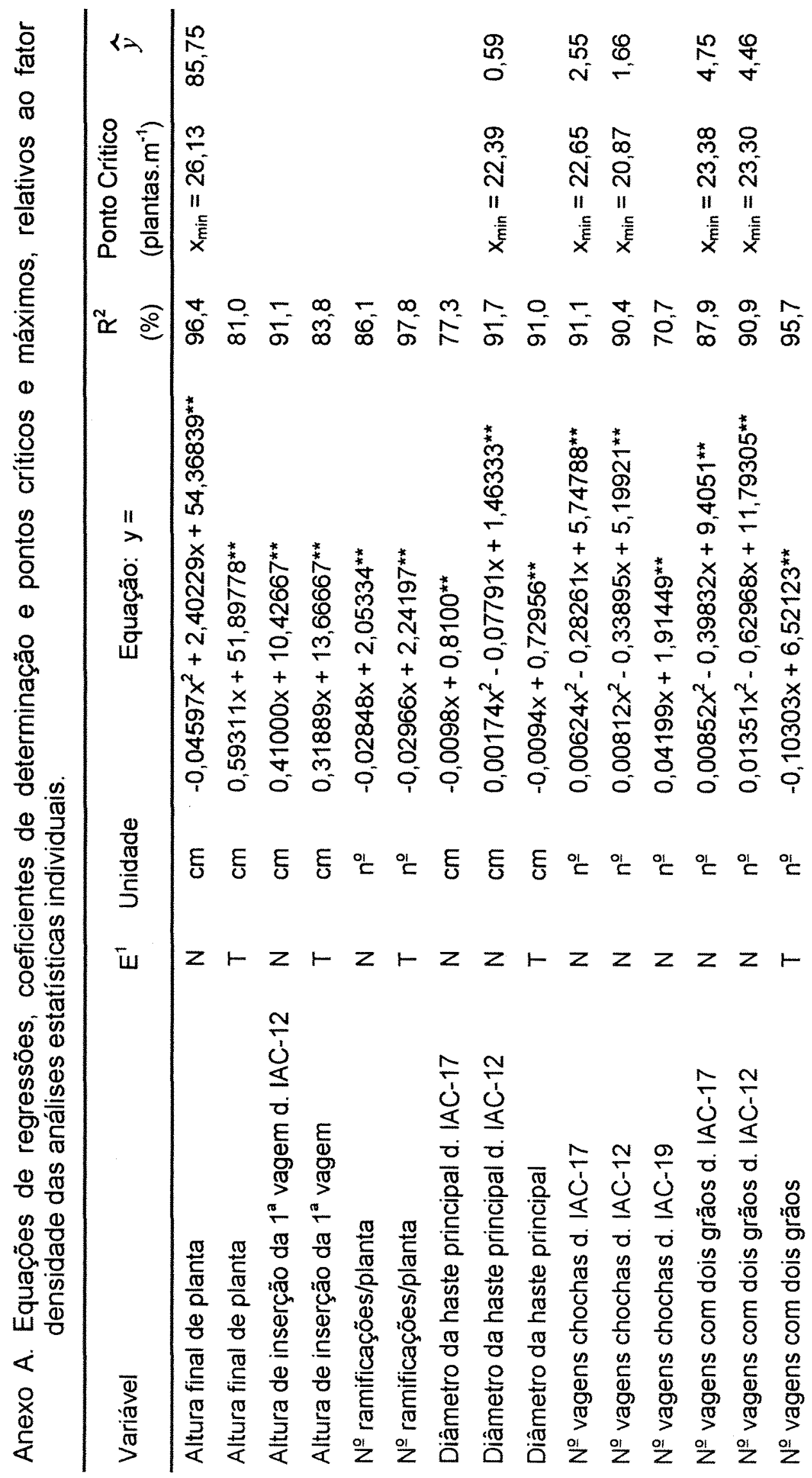




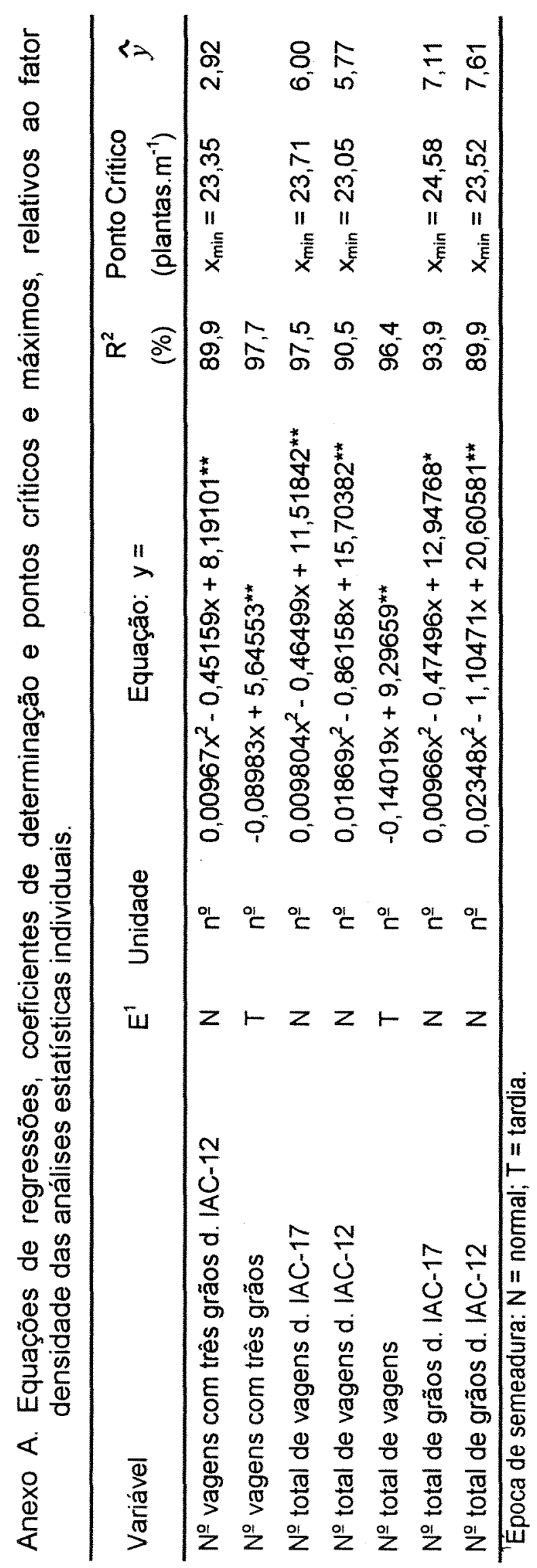




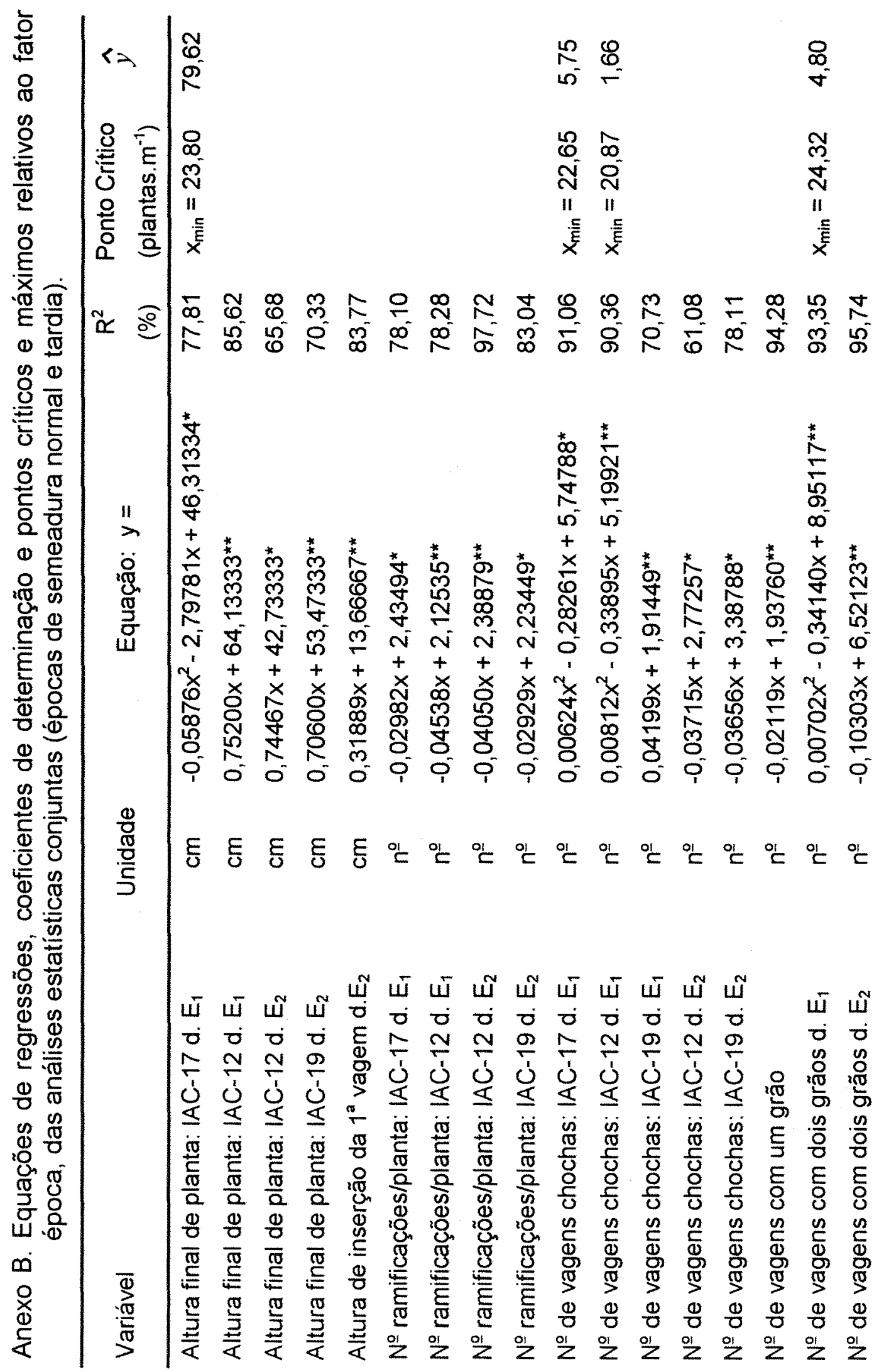




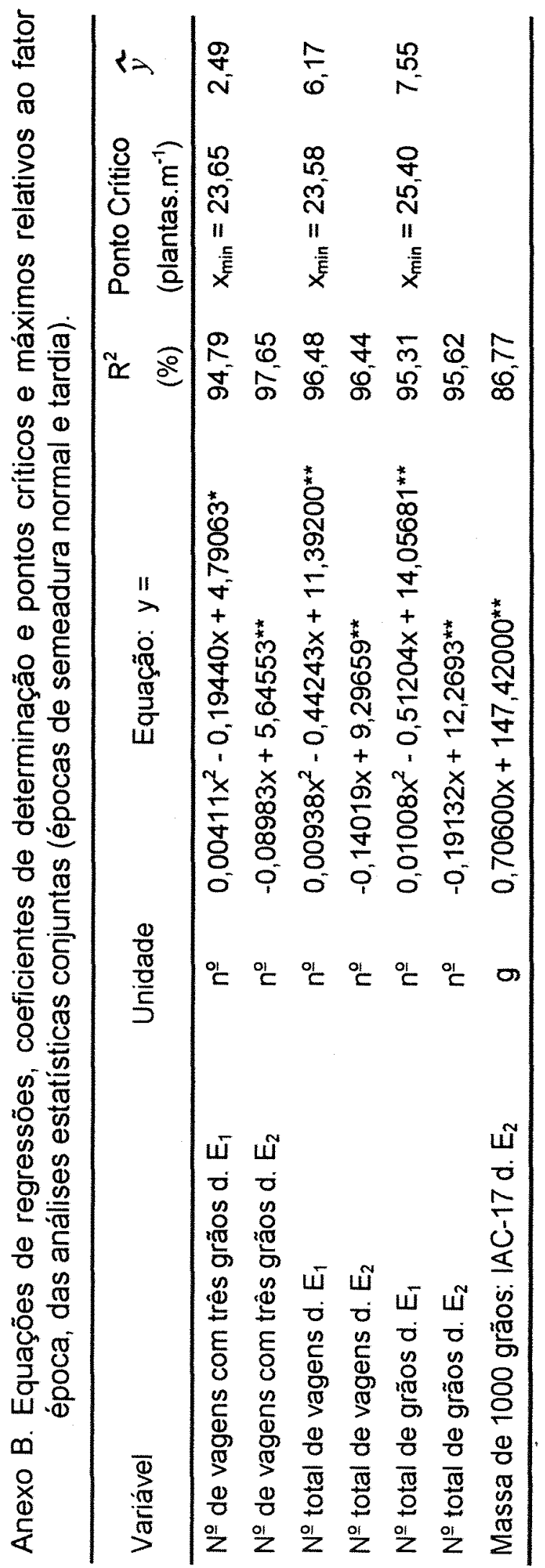




\section{REFERÊNCIAS BIBLIOGRÁFICAS}

BARNI, N.A.; BERGAMASCHI, H. Alguns princípios técnicos para a semeadura. In: MIYASAKA, S.; MEDINA, J.C. (Ed.) A soja no Brasil. Campinas: ITAL, 1981. p. 453-685.

BERGAMASCHI, H.; BERLATO, M.A.; WESTPHALEM, S.L. Épocas de semeadura de soja no Rio Grande do Sul: avaliação e interpretação dos ensaios ecológicos de soja. Ipagro Informa, n.18, p.7-14, 1997.

BHÉRING, M.C. Influência de épocas de plantio sobre algumas características agronômicas e qualidade das sementes de soja (Glycine max (L.) Merrill). Viçosa, 1989. 57p. Dissertação (Mestrado) - Universidade Federal de Viçosa.

BRASIL. Ministério da Agricultura. Regras para análise de sementes. Brasilia: LANARVISNDA, 1992. 365p.

BUENO, L.C.S.; SEDYIAMA, C.S.; VIEIRA, C. Efeitos de espaçamento, densidade e época de plantio sobre duas variedades de soja. Experientiae, v.20, n.10, p.263-287, 1975.

BURRIS, J.S. Effect of seed maturation and plant population on soybean seed quality. Agromomy Journal, v.65, n.1, p. 440-441, 1973. 
CÂMARA, G.M.S. Efeito do fotoperíodo e da temperatura no crescimento, florescimento e maturação de cultivares de soja (Glycine max (L.) Merrill). Viçosa, 1991. 266p. Tese (Doutorado) - Universidade Federal de Viçosa.

CÂMARA, G. M. S. Ecofisiologia da cultura da soja e rendimento. In: CÂMARA, G. M. S. (Ed.) Soja: tecnologia da produção. Piracicaba: ESALQ, Depto. de Agricultura, 1998a. p.256-277.

CÂMARA, G. M. S. Fenologia da soja. Informações Agronômicas, n. 82, p.1-6, 1998b.

CARRARO, I.M.; SEDIYAMA, C.S.; ROCHA, A.; BAIRRÃO, J.F.M. Efeito da época de semeadura sobre altura e rendimento de doze cultivares de soja em Cascavel, PR. In: SEMINÁRIO NACIONAL DE PESQUISA DE SOJA, 3., Campinas, SP. Anais. Londrina: EMBRAPA, CNPSo, 1984. p.70-81.

CARTTER, J.L.; HARTWIG, E.E. The management of soybeans. In: NORMAN, A.G. (Ed.) The soybean. New York: Academic Press, 1967. p.162-221.

CORSO, J.C. Efeitos da mistura de sal de cozinha a inseticidas recomendados para o controle de percevejos. In: EMPRESA BRASILEIRA DE PESQUISA AGROPECUÁRIA. Centro Nacional de Pesquisa de Soja. Resultados de pesquisa da soja 1986/87. Londrina, 1988. p.77-78.

EMPRESA BRASILEIRA DE PESQUISA AGROPECUÁRIA. Centro Nacional de Pesquisa de soja. Recomendações técnicas para a cultura da soja na região central do Brasil 1996/97. Londrina, 1996. 149p. (EMBRAPA. CNPSo. Documento, 88). 
FEHR, W.R.; CAVINESS, C.E. Stages of soybean development. Ames: lowa State University of Science and Technology, 1977. 11p.

FRANÇA NETO, J.B.; HENNING, A.A. Qualidade fisiológica e sanitária de sementes de soja. Londrina: EMBRAPA, CNPSo, 1984. 39p. (EMBRAPA. CNPSo. Circular Técnica, 9).

GAUDÊNCIO, C.A.A.; GAZZIERO, D.L.P.; JASTER, F.; GARCIA, A.; WOBETO, C. População do plantas de soja no sistema de semeadura direta para o Centro-Sul do Estado do Paraná. Comunicado Técnico do Centro Nacional de Pesquisa de Soja, n.47, p.1-4, 1990.

GILIOLI, J.L.; PALUDZYSZYN FILHO, E.; ALMEIDA, L.A. Efeitos da interação densidade de semeadura e adubação fosfatada sobre algumas características agronômicas da soja. In: SEMINÁRIO NACIONAL DE PESQUISA DE SOJA, 1., Londrina, 1978. Anais. Londrina: EMBRAPA, CNPSo, 1979. p. 39-51.

HARTWIG, E.E. Varietal development. In: CALDWELL, B.E. (Ed.) Soybeans: improvement, production, and uses. Madison: American Society of Agronomy, 1973. p.187-210.

HINSON, K.; HANSON, W.D. Competition studies in soybeans. Crop Science, v.2, n.2, p.117-123, 1962.

KLAR, A. V.; CATANEO, A.; DENADAI, I. M. A.; GISHIFU, M. T. Os efeitos da água, da densidade e da época de plantio sobre uma cultura de soja (Glycine $\max$ (L.) Merrill). Cientifica, v. 14, n. 1/2, p. 115-128, 1986. 
LAM-SANCHES, A.; VELOSO, E.J. Efeito do espaçamento e da densidade de plantio, sobre várias características agronômicas na cultura da soja (Glycine max (L.) Merrill), variedade "Viçoja" em Jaboticabal, SP. Científica, v.2, n.2, p. 137-148, 1974a.

LAM-SANCHES, A.; VELOSO, E.J. Época de plantio na cultura da soja (Glycine max (L.) Merrill), cultivares "Santa Rosa" e "Viçoja" em Jaboticabal, SP. Científica, v.7, n.2, p.225-234, 1974b.

MARCHIORI, L. F. S. Desempenho vegetativo e produtivo de três cultivares de soja em cinco densidades populacionais nas épocas normal e safrinha. Piracicaba, 1998. 55p. Dissertação (Mestrado.) - Escola Superior de Agricultura "Luiz de Queiroz", Universidade de São Paulo.

MARCOS FILHO, J. Produção de sementes de soja. Campinas: Fundação Cargill, 1986. 86p.

MARCOS FILHO, J.; NOVEMBRE, A.D.L.C. Características agronômicas e fenologia da soja (Glycine max (L.) Merrill) sob influência da época de semeadura: relatório técnico apresentado ao Conselho de Desenvolvimento Científico e Tecnológico (CNPq). Piracicaba: ESALQ, 1990. 57p.

MASCARENHAS, H. A. A.; TANAKA, R. T. Soja. In: RAIJ, B. van; CANTARELLA, H.; QUAGGIO, J. A.; FURLANI, A. M. C. (Ed.) Recomendações de adubação e calagem para o Estado de São Paulo. 2. ed. Campinas: Instituto Agronômico, 1996. p.202 - 203. (IAC. Boletim Técnico, 100). 
MEDINA. P.F. Produção de sementes de cultivares precoces de soja, em diferentes épocas e locais do estado de São Paulo. Piracicaba, 1994. 173p. Tese (Doutorado) - Escola Superior de Agricultura "Luiz de Queiroz", Universidade de São Paulo.

MELFI, F. Efeito do acamamento na produtividade e na qualidade fisiológica e sanitária de sementes de soja (Glycine max (L.) Merrill) colhidas em duas épocas. Viçosa, 1996. 44p. Dissertação (Mestrado) - Universidade Federal de Viçosa.

MELHORANÇA, A.L.; MESQUITA, A.N. Efeito do espaçamento e épocas de semeadura sobre o rendimento e características agronômicas da soja em Dourados, MS. Pesquisa Agropecuária Brasileira, v.17, n.5, p. 729-732, 1982.

MILANEZ, D.; FONSECA, W.F.; PACOVA, B.E.V.P. Pesquisa e experimentação com soja (Glycine $\max ($ L.) Merrill) no Estado do Espírito Santo. II. Estudo de época de plantio. Revista Ceres, v.25, n.137, p.36-41, 1978.

NAKAGAWA, J.; MACHADO, J.R.; ROSOLEM, C.A. Efeito da densidade de plantas e da época de semeadura na produção e qualidade de sementes de soja. Revista Brasileira de Sementes, v.8, n.3, p. 99-112, 1986a.

NAKAGAWA, J.; MACHADO, J.R.; ROSOLEM, C.A. Efeito da densidade de plantas no comportamento de cultivares de soja. Cientifica, v.15, n.1/2, p.23-36, 1987. 
NAKAGAWA, J.; ROSOLEM, C.A.; MACHADO, J.R. Épocas de semeadura da soja. I. Efeitos na produção de grãos e nos componentes da produção. Pesquisa Agropecuária Brasileira, v.18, n.11, p.1187-1198, 1983.

NAKAGAWA, J.; ROSOLEM, C.A.; MACHADO, J.R. Efeito da densidade de plantas no comportamento de cultivares de soja, em duas épocas de semeadura. Pesquisa Agropecuária Brasileira, v.23, n.9, p.1003-1014, 1988.

NAKAGAWA, J.; ROSOLEM, C.A.; MACHADO, J.R. Efeito da densidade de plantas sobre o comportamento de dois cultivares de soja. Revista de Agricultura, v.61, n.3, p.277-290, 1986b.

NAKAGAWA, J.; ROSOLEM, C.A.; MACHADO, J.R. Efeito da época de semeadura sobre o tamanho e o peso de cem sementes de soja. Científica, v.19, n.1, p. 151-167, 1991.

NOGUEIRA, S.S.S.; HAAG, P.H.; CARELLI, M.L.C.; FAHL, J.I; MAEDA, J.A. Variação dos componentes da produção de dois cultivares de soja, UFV-1 e IAC-7, em função da época de semeadura. Anais da Escola Superior de Agricultura "Luiz de Queiroz", v.41, n.1, p.141-153, 1984.

PANIZZI, A.R. Manejo integrado de pragas da soja no Brasil. In: CROCOMO, W.B. (Ed.) Manejo integrado de pragas. São Paulo: UNESP, 1990. p.293-321.

QUEIROZ, E.F. Efeito de época de plantio e população sobre o rendimento e outras características agronômicas de quatro cultivares de soja (Glycine $\max ($ L.) Merrill). Porto Alegre, 1975. 129 p. Dissertação (Mestrado) Faculdade de Agronomia., Universidade Federal do Rio Grande do Sul. 
REIS, M.S.; VIEIRA, C.; ANDRADE, A.M.S.; SEDIYAMA, T. Efeitos do espaçamento e da densidade de plantio sobre a variedade de soja UFV-1 no Triângulo Mineiro. Revista Ceres, v.24, n.134, p.412-419, 1977.

RITCHIE, S. W.; HANWAY, J. J.; THOMPSON, H. E.; BENSON, G. O. How a soybean plant develops. Ames: lowa State University of Science and Thechnology, Cooperative Extension Service, 1994. 20p. (Special Report, 53).

ROCHA, V.S.; OLIVEIRA, A.B.; SEDIYAMA, T.; GOMES, J.L.L.; SEDIYAMA, C.S.; PEREIRA, M.G. A qualidade da semente de soja. Viçosa: Universidade Federal de Viçosa, 1984. 76 p. (UFV. Boletim, 188).

ROSOLEM, C.A.; SILVÉRIO, J.C.O.; NAKAGAWA, J. Densidade de plantas na cultura da soja. Pesquisa Agropecuária Brasileira, v.18, n.9, p. 977-984, 1983.

SEDIYAMA, T.; PEREIRA, M. G.; SEDIYAMA, C. S.; GOMES, J. L. L. Cultura da soja: I parte. Viçosa: Imprensa Universitária, 1985. 96p.

SEDIYAMA, C.S.; VIEIRA, C.; SEDIYAMA, T.; CARDOSO, A.A.; ESTEVÃO, H.H. Influência do retardamento da colheita sobre a deiscência das vagens e sobre a qualidade e poder germinativo das sementes de soja. Experientiae, v.14, n.5, p.117-141, 1972.

SNEDECOR, G. W.; COCHRAN, W. G. Statistical methods. 8.ed. Ames: lowa State University Press, 1989. 503 p. 
SOSA-GÓMEZ, D.R.; TAKASHI, C.Y.; MOSCARDI, F. Determinação de sinergismo e susceptibilidade diferencial de Nezara viridula (L.) e Euschistus heros (F.) (Heteroptera: Pentatomidae) à inseticidas em misturas com cloreto de sódio. Anais da Sociedade Entomológica do Brasil, v.22, n.3, p.596-76, 1993.

TRAGNAGO, J.L;; BONETTI, L.P. Diferentes épocas de semeadura no rendimento e outras características de alguns cultivares de soja no Rio Grande do Sul. In: SEMINÁRIO NACIONAL DE PESQUISA DE SOJA, 3., Campinas, 1984. Anais. Londrina: EMBRAPA, CNPSo, 1984. p.57-69.

URBEN FILHO, G.; SOUZA, P.I.M. Manejo da cultura da soja sob cerrado: época, densidade e profundidade de semeadura. In: ARANTES, N. E. ; SOUZA, P. I. M. (Ed.) Cultura da soja nos cerrados. Piracicaba: POTAFOS, 1993. p.267-298.

VAL, W.M.C.; BRANDÃO, S.S.; GALVÃO, J.D.; GOMES, F.R. Efeito do espaçamento entre fileiras e da densidade na fileira sobre a produção de grãos e outras características agronômicas da soja (Glycine max (L.) Merrill). Experientiae, v.12, n.12, p.431-475, 1971.

YUYAMA, K. Ensaio de épocas de plantio sobre várias características agronômicas na cultura de soja (Glycine max (L.) Merrill), variedades "Júpiter", "Prata", "Oriente" e "Pelicano", em Aripuanã-MT. Acta Amazonica, v.9, n.3, p.419-436, 1979. 
APÊNDICES 

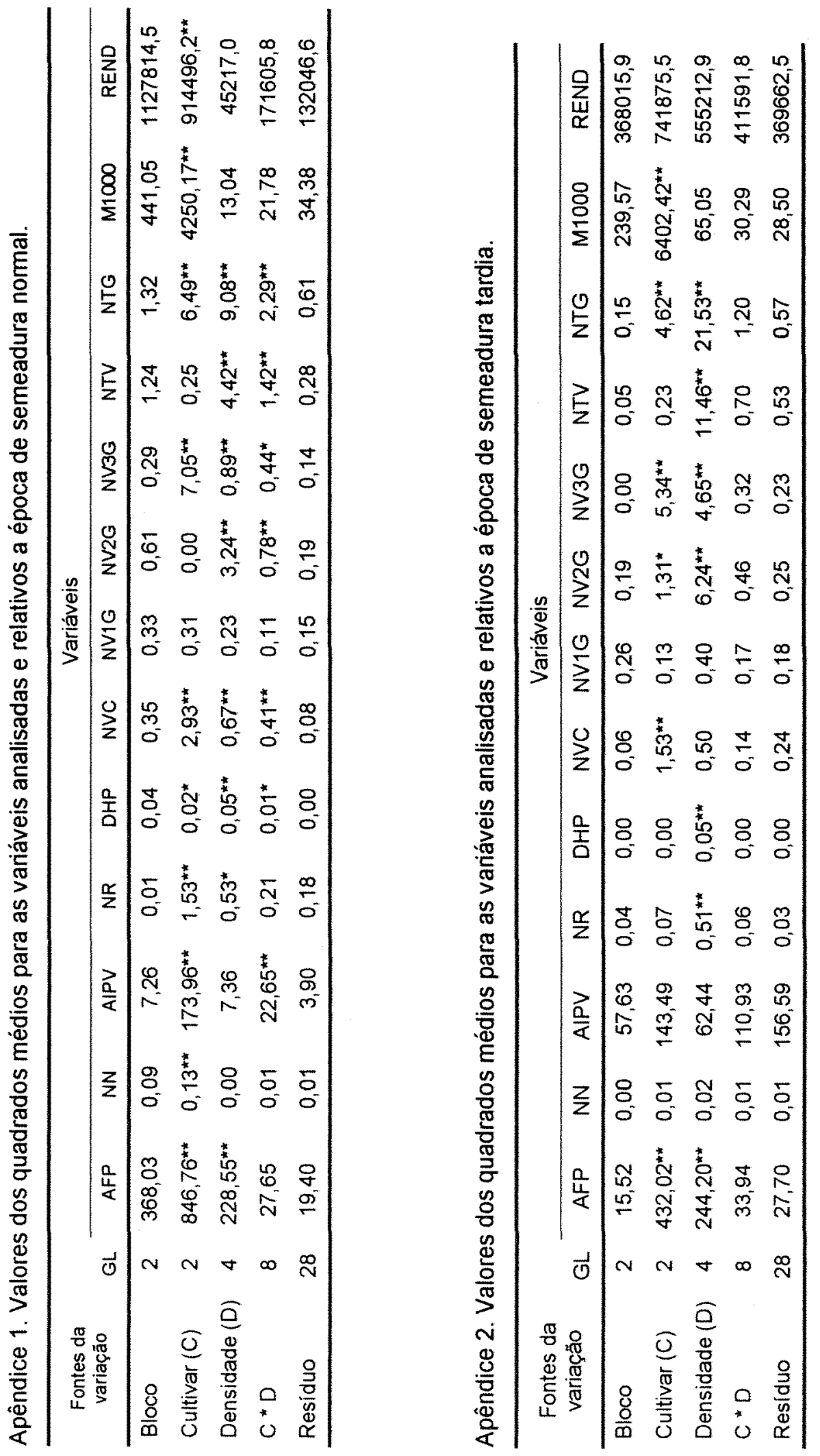


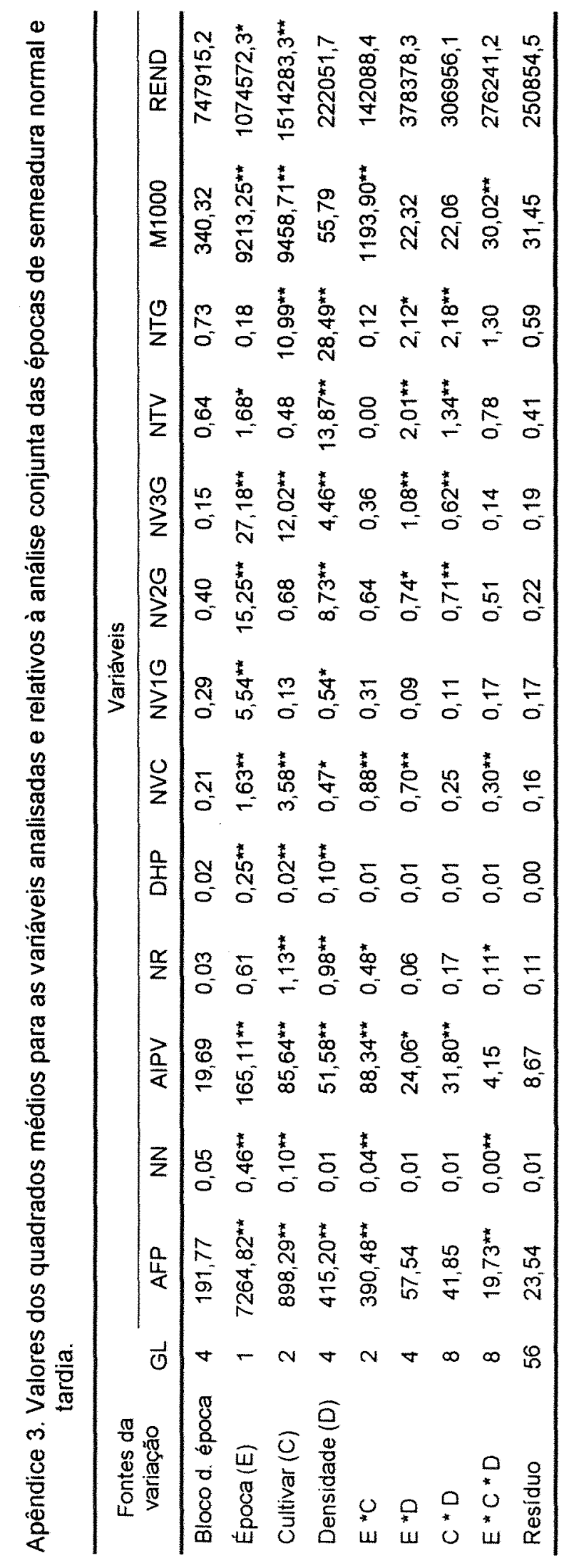

